UNIVERSIDADE DE BRASÍLIA

FACULDADE DE EDUCAÇÃO

PROGRAMA DE PÓS-GRADUAÇÃO EM EDUCAÇÃO

INFÂNCIA E CRIANÇA: UM ESTUDO EM REPRESENTAÇÕES SOCIAIS COM PROFESSORES DE CENTROS DE EDUCAÇÃ̃O DA PRIMEIRA INFÂNCIA - CEPIs / DF.

ADAIL SILVA PEREIRA DOS SANTOS

Brasília - DF

Março, 2016. 
Adail Silva Pereira dos Santos

\section{INFÂNCIA E CRIANÇA: UM ESTUDO EM REPRESENTAÇÕES SOCIAIS COM PROFESSORES DE CENTROS DE EDUCAÇÃO DA PRIMEIRA INFÂNCIA - CEPIs / DF.}

Dissertação apresentada ao programa de

Pós-Graduação em Educação da

Universidade de Brasília/UnB, como exigência parcial para obtenção do título de mestre em Educação, sob a orientação da $\operatorname{prof}^{\mathrm{a}}$. Dra ${ }^{\mathrm{a}}$. Teresa Cristina Siqueira Cerqueira.

Brasília - DF

Março, 2016. 


\section{INFÂNCIA E CRIANÇA: UM ESTUDO EM
RSENTAÇÕES SOCIAIS COM PROFESSORES DE
ROS DE EDUCAÇÃO DA PRIMEIRA INFÂNCIA - \\ INFÂNCIA E CRIANÇA: UM ESTUDO EM
REPRESENTAÇÕES SOCIAIS COM PROFESSORES DE
CENTROS DE EDUCAÇÃO DA PRIMEIRA INFÂNCIA - \\ INFÂNCIA E CRIANÇA: UM ESTUDO EM
REPRESENTAÇÕES SOCIAIS COM PROFESSORES DE
CENTROS DE EDUCAÇÃO DA PRIMEIRA INFÂNCIA - CENTROS DE EDUCAÇÃO DA PRIMEIRA INFANCIA -
CEPIS / DF.}

Este trabalho foi julgado adequado para a obtenção do título de Mestre em Educação e aprovado em sua forma final pela Faculdade de Educação da Universidade de Brasília.

\footnotetext{
Prof $^{\mathrm{a}}$. Dr ${ }^{\mathrm{a}}$. Teresa Cristina Siqueira Cerqueira

Orientadora

Prof $^{a}$. Dr ${ }^{\mathrm{a}}$. Cristina Massot Madeira Coelho Membro - FE - UnB

Prof $^{\mathrm{a}}$. Dr ${ }^{\mathrm{a}}$ Erenice Natália Soares de Carvalho

Membro externo - Universidade Católica de Brasília - UCB

Prof $^{\mathrm{a}}$. Dr $^{\mathrm{a}}$. Edileuza Fernandes Da Silva

Membro suplente- FE - UnB
}

Brasília, março de 2016. 
Uma frase, um enigma, uma teoria [...] aguçam a curiosidade, prendem a atenção. Fragmentos de diálogo, leituras descontínuas, expressões ouvidas [...] misturam-se às suas impressões; brotam as recordações, as experiências comuns apossam-se delas. Graças a esses falatórios, não só as informações são transmitidas e os hábitos dos grupos confirmados, mas cada um adquire uma competência enciclopédica acerca do que é o objeto de discussão. À medida que a conversa coletiva progride [...] a sociedade começa a ser habitada por novas frases e visões.

(SERGE MOSCOVICI, 2011) 


\section{AGRADECIMENTOS}

Gratidão! Esta é a palavra que traduz toda a caminhada percorrida. A gratidão revela o mais profundo carinho por todas as pessoas que contribuíram direta e indiretamente nesse estudo.

Gratidão aos Céus, pela força a mim concedida diante de toda adversidade vivida.

Gratidão à minha orientadora, professora Teresa Cristina Siqueira Cerqueira que, diante dos desafios surgidos em seu caminho, não esmoreceu e continuou com a mesma dedicação e competência de sempre. Gratidão pela disponibilidade, pelas orientações, por abrir as portas de sua casa para nos receber, pela delicadeza, sabedoria e boniteza humana. A ela, meu eterno carinho e respeito.

Gratidão à professora Cristina Massot Madeira Coelho pela sua disponibilidade, cooperação, seriedade, pelo fato de estar sempre acessível, pela contribuição e atenção.

Gratidão à professora Erenice Natália Soares de Carvalho, pela disponibilidade e possibilidade de ampliar o meu caminho.

Gratidão à professora Edileuza Fernandes da Silva, pela dedicação de sempre, por sua história e contribuições na educação do Distrito Federal e por fazer parte desse momento ímpar da minha vida.

Gratidão à professora Inês Maria Marques Zanforlin Pires de Almeida quem me instigou a buscar nos caminhos da pesquisa acadêmica o sentido da escuta sensível e o prazer em desvelar o não dito. Obrigado.

Gratidão aos professores da UnB que contribuíram para a minha formação e história.

Gratidão à MAINHA (minha mãe querida), mulher resiliente, que se refez nas lutas diárias e se dedicou com força e amor no desafio de seguir uma caminhada de vida ao lado de oito filhos. Amor que não se mede.

Gratidão aos grandes amigos, que se fizeram em mim fortaleza, ajudando a alicerçar a força necessária para a minha caminhada no mestrado. Mauro Gleisson, Verinez Carlota, Elaine Rosa, Surama Castro, Vânia Barbosa e à todas e todos que direta e indiretamente entenderam minha ausência ao longo desse mestrado sem nunca deixarem de me incentivar. 
Gratidão aos meus irmãos e irmãs pelo apoio. Mas gostaria de, principalmente, marcar aqui minha gratidão à minha irmã Adeilta (Dede) e ao meu cunhado-irmão Magno que foram importantíssimos em um momento difícil e significativo da minha caminhada. Muito obrigado pela presença e pelo amor dedicado.

Gratidão aos amores que se vão e aos que vem. Somar amor na caminhada é fundamental para aguçar um olhar mais sensível e aproximar a fraternidade humana à busca pelo entendimento de si e do mundo. Sou grato ao amor!

Gratidão aos colegas do GRUPPE (Grupo de Estudos e Pesquisas em Psicologia e Educação, coordenado pela professora Doutora Teresa Cristina Siqueira Cerqueira): Daniele, Denise, Erasmo, Elisvânia, Eunice, Hélio, Luciano, Karen, Kátia Rosa, Kátia Maragon Mariana e Rita pelas oportunidades de discussões e trocas de conhecimento sempre tão enriquecedoras e pela amizade tão reestabelecedora da saúde mental.

Gratidão às professoras dos Centros de Educação da Primeira Infância do Distrito Federal (CEPI), colegas de profissão, que se dispuseram a participar desta pesquisa, pela generosidade em compartilhar suas experiências e com isso permitir a construção deste trabalho.

Gratidão a todos os amigos e amigas de profissão que fizeram e fazem parte da minha caminhada e por cada um e cada uma, ao seu modo, contribuírem para o meu crescimento como professor e pesquisador na Educação pública do Distrito Federal.

Gratidão à SEEDF por me conceder afastamento remunerado, possibilitando um envolvimento maior com o presente trabalho.

Gratidão à Fernanda Plentz pela generosidade e paciência nas explicações sobre o Essemble de Programmes Permettant I'Analyse des Evocations (EVOC).

Minha eterna gratidão às CRIANÇAS! À elas minha dedicação, meu trabalho, meus estudos e minha escuta sensível. 


\section{LISTA DE QUADROS}

Quadro 1: Características do núcleo central e elementos periféricos das representações sociais

Quadro 2: Demonstrativo do contexto e participantes........................................................57

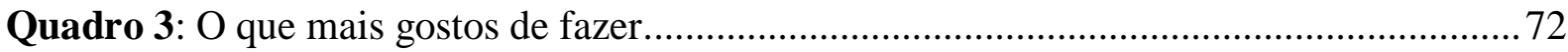

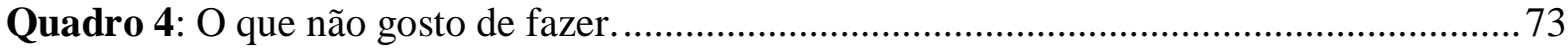

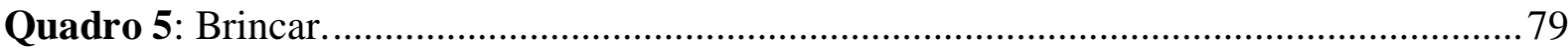

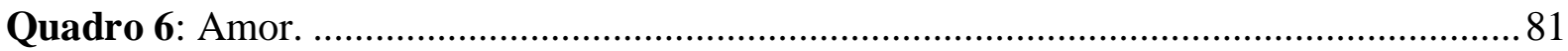

Quadro 7: O brincar como função primordial assumida pelo sujeito que vive a infância......87

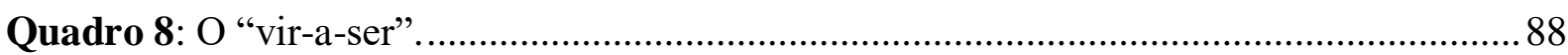

Quadro 9: Perspectiva acerca das experiências vividas... .................................................90

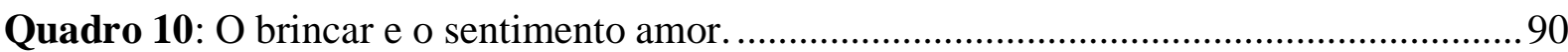




\section{LISTA DE FIGURAS}

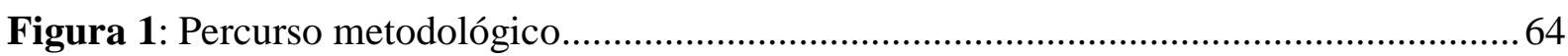

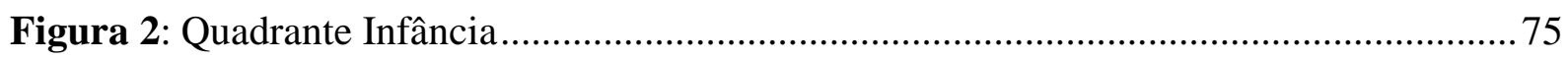

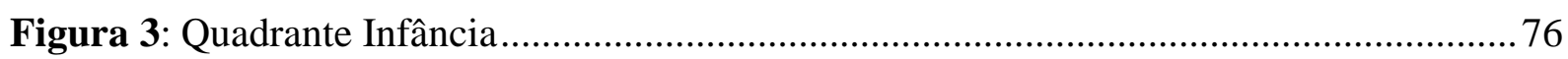

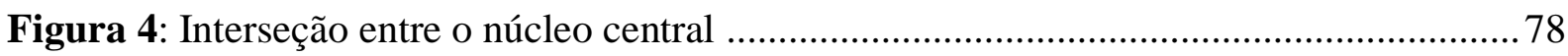




\section{LISTA DE GRÁFICOS}

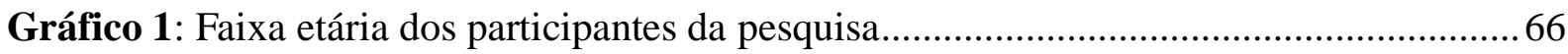

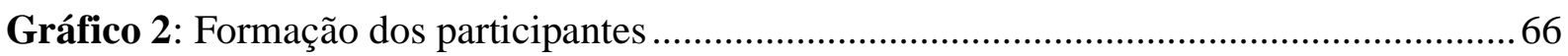

Gráfico 3: Tempo de atuação na Educação Infantil.......................................................... 70

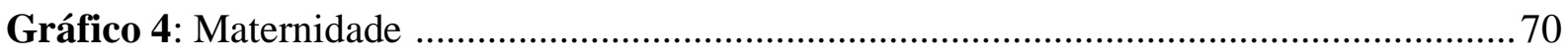

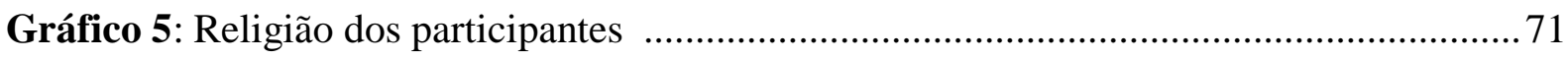




\section{LISTA DE SIGLAS E ABREVIATURAS}

\begin{tabular}{|c|c|}
\hline CEPIs & Centros de Educação da Primeira Infância \\
\hline CLT & Consolidação das Leis do Trabalho \\
\hline DF & Distrito Federal \\
\hline EAPE & Escola de Aperfeiçoamento dos Profissionais da Educação \\
\hline EVOC & Ensemble de Programmes Permettant I'Analyse dês Evocations \\
\hline GRUPPE & Grupo de Estudos e Pesquisas em Psicologia e Educação \\
\hline LDBEN & Lei de Diretrizes e Bases da Educação Nacional \\
\hline NC & Núcleo Central \\
\hline PAC & Programa de Aceleração do Crescimento \\
\hline PDE & Plano de Desenvolvimento da Educação \\
\hline PPGE-UnB & $\begin{array}{l}\text { Programa de Pós-Graduação em Educação da Universidade de } \\
\text { Brasília }\end{array}$ \\
\hline PROINFÂNCIA & $\begin{array}{l}\text { Programa Nacional de Reestruturação e Aquisição de Equipamentos } \\
\text { para a Rede Escolar Pública de Educação Infantil }\end{array}$ \\
\hline $\mathbf{R S}$ & Representações Sociais \\
\hline SEEDF & Secretaria do Estado de Educação do Distrito Federal \\
\hline TALP & Técnica de Associação Livre de Palavras \\
\hline TRS & Teoria das Representações Sociais \\
\hline ZDP & Zona de Desenvolvimento Proximal \\
\hline UnB & Universidade de Brasília \\
\hline
\end{tabular}




\section{RESUMO}

O presente trabalho tem como objetivo analisar as representações sociais sobre infância e criança dos professores dos Centros de Educação da Primeira Infância da cidade / DF. Para tanto, procedeu-se a uma abordagem plurimetodológica com base na Teoria das Representações Sociais (MOSCOVICI, 2011). A geração e análise de dados aconteceram em três momentos. No primeiro, caracterizou-se os sujeitos participantes da pesquisa para identificação de suas relações sociais, profissionais, bem como o perfil do grupo. No segundo estudo, buscou-se identificar os elementos constituintes da representação social, utilizando a técnica de associação livre, tendo "infância" e "criança" como palavras indutoras das evocações. A análise revelou elementos referentes ao brincar, amor, alegria, desenvolvimento, aprendizagem, cuidado, etapa de vida, carinho e liberdade. Utilizando na análise o quadro das quatro casas de Vergès, observamos que o núcleo central contém evocações relacionadas a "brincadeiras" e ao "amor". Os elementos intermediários referem-se ao contexto (escola) e às reminiscências e marcas da infância. Evocações relacionadas às vivências pessoais das professoras foram destacadas no sistema periférico, que protege o núcleo central. No terceiro estudo, buscando compreender a dinâmica da representação, foram realizados dois grupos focais. A análise revelou a existência de interseção definindo duas categorias, em torno das quais são evidenciados os diferentes significados que circulam nas representações das professoras: a infância vivida (baseadas nas vivências das professoras) e as brincadeiras (baseadas também nas vivências, bem como nas comunicações e trocas diárias entre elas). $\mathrm{Na}$ discussão, as professoras constroem a representação de si mesmas e de suas infâncias, considerando a criança como um "vir-aser" (cultura na construção da cultura), em virtude das mudanças que percebem no cotidiano pedagógico. A representação "brincar" e "amor", que predomina no núcleo central da representação e vem impregnando o cotidiano da Educação Infantil desde os seus primórdios, sendo mesclado com as vivências das professoras, adquirindo uma conotação mais sociológica, fixada na sociedade, o que fortalece a "preservação das culturas infantis".

Palavras-chave: Infância. Criança. Representação Social. 


\begin{abstract}
This study aims to analyze the social representations of childhood and child of teacher education centers Early Childhood City / DF. Therefore, we proceeded to a polimetodology approach based on the Theory of Social Representations (MOSCOVICI, 2011). The generation and data analysis was done in three moments. Firstly, we characterized the participants to identify their social, professional, and the group's profile. Secondly, we sought to identify the elements of social representation, using free association technique, and "child" and "child" as inducing words evocations. The analysis revealed elements for the play, love, joy, development, learning, care, life stage, love and freedom. Using the analysis the framework of the four houses of Vergès, we had observed that the core contains evocations related to "play" and "love." The intermediate elements refer to the context (school) and the reminiscences and childhood brands. Evocations related to the personal experiences of the teachers had highlighted at peripheral system, which protects the core. The third study, was trying to understand the dynamics of representation, were two focus groups. The analysis revealed that the existence of intersection can defining two categories, around which the different meanings circulating in the representations of the teachers are highlighted: the childhood (based on teacher's the experiences) and games (also based on experiences and communications and daily exchanges between them). During discussion, teachers are constructing the representation of themselves and their childhoods, considering the child as a "come-to-be" (culture in the development of culture), because of the changes they perceive in everyday teaching. The representation of "play" and "love," which prevails in the core of representation and is imbuing the everyday childhood education from beginning, combining teacher's experiences, acquiring more sociological connotation attached to the society, which strengthens the "preservation of children's cultures."
\end{abstract}

Keywords: Childhood. Child. Social representation. 


\section{SUMÁRIO}

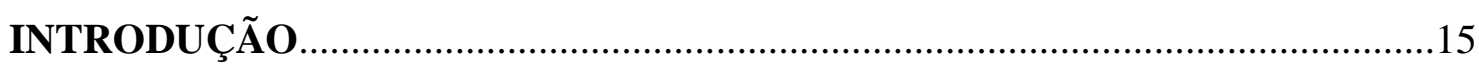

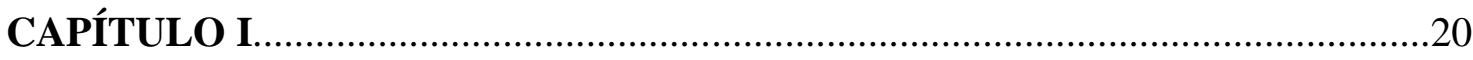

INFÂNCIA E CRIANÇA - Da incompletude social à (re)construção social do

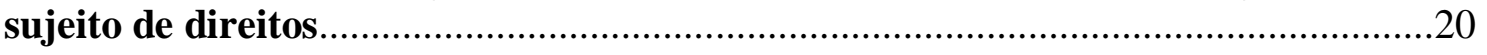

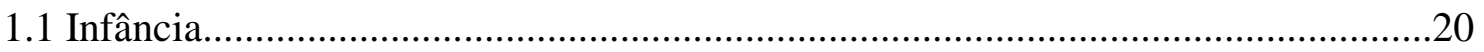

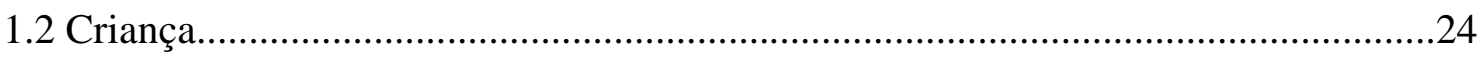

1.3 Sociologia da Infância e as Teorias do Desenvolvimento: Possíveis relações......... 27

1.4 Olhares contemporâneos sobre a infância e a criança................................................33

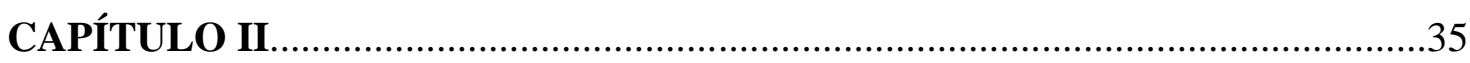

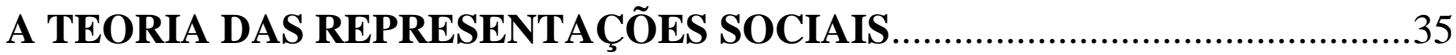

2.1 O movimento multifacetado das representações sociais: Dinâmicas.........................37

2.2 Abordagem estrutural das representações sociais................................................43

2.3 As Representações Sociais no contexto escolar..................................................45

2.4 As representações sociais e o diálogo com a sociologia........................................47

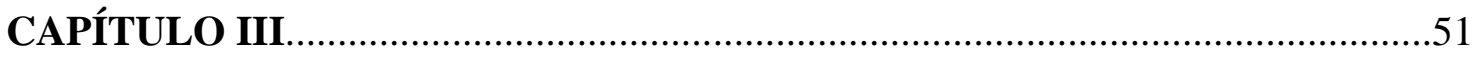

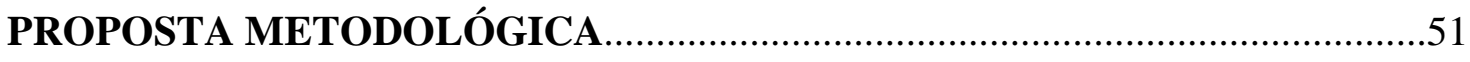

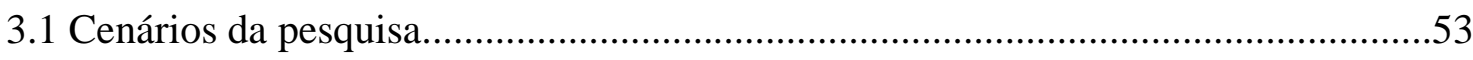

3.2 Conhecendo os cenários dos Centros de Educação da Primeira Infância: Um breve

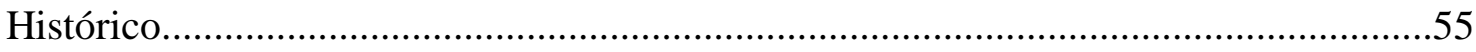

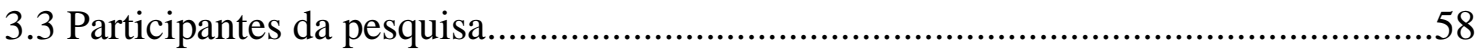

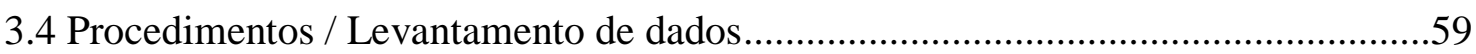

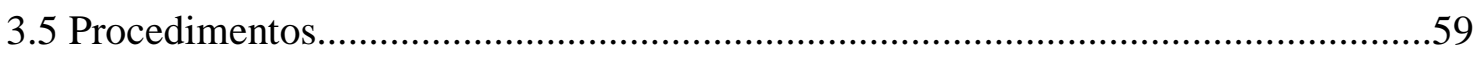

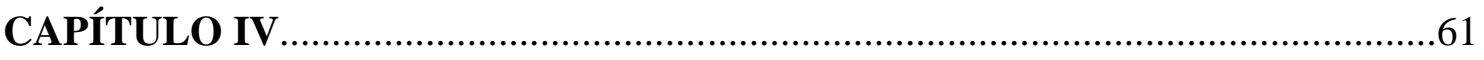

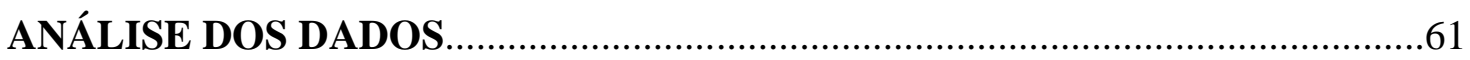

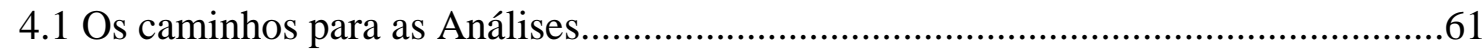


4.2 Primeiro Momento - Caracterização dos sujeitos da pesquisa...................................65

4.3 Segundo Momento - Análise das Evocações...........................................................74

4.4 Terceiro Momento - Análise dos Grupos Focais...................................................83

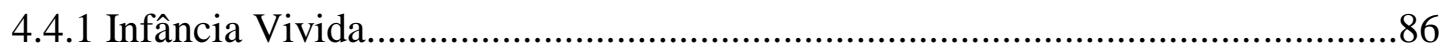

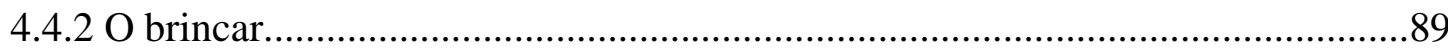

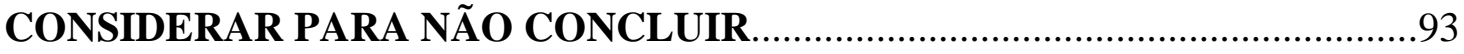

REFERÊNCIAS

APÊEDICES A - Termo de Consentimento Livre e Esclarecido 1............................102

APÊNDICES B - Termo de Consentimento Livre e Esclarecido 2 ..............................104

APÊNDICES C - Instrumento para Caracterização dos sujeitos da pesquisa..............105

APÊNDICES D - Instrumento de Evocação Livre de Palavras / Criança.....................107

APÊNDICES E - Instrumento de Evocação Livre de Palavras / Infância...................109

ANEXOS A 


\section{INTRODUÇÃO}

A investigação, por meio da análise das representações de professores sobre infância e criança, é objeto de estudo relativamente novo, que vem objetivando entender o complexo e multifacetado processo de construção social da infância, o lugar da criança e o papel que a escola vem desempenhando diante da "dimensão simbólica nas culturas da infância”. (SARMENTO, 2002, p. 3). Pesquisas em relação ao estudo da infância e da criança nos espaços educativos vêm ganhando um lugar significativo no cenário acadêmico. Contudo, segundo Corsaro (2011), as Ciências Sociais e Humanas tardaram em focar a criança e a infância como objetos centrais de suas pesquisas. $\mathrm{O}$ tempo alongou-se ainda mais em relação a sinalizar nas pesquisas e em suas análises as relações entre infância, criança, escola e sociedade, entendendo a criança como sujeito histórico e partícipe da dinâmica social, tendo como eixo de suas investigações o registro das representações sociais dos adultos imersos no cotidiano com os pequenos (sujeitos da infância). Essa imersão no cotidiano com professores e suas representações e a percepção por uma emergência acerca da construção social da infância, ajudam no movimento desse caminho teórico metodológico.

O tempo percorrido no caminhar docente, a atuação como gestor do Jardim de Infância 116 de Santa Maria - DF, as andanças pelo país como Coordenador Nacional de formação Continuada, a perspectiva como gestor central no gabinete da Secretaria de Estado de Educação do Distrito Federal e a proximidade com os professores das escolas públicas, observamos que cada um possui uma teoria implícita que orienta o cotidiano com as crianças, suas formas de atuação e suas posturas diante do construto social da infância nos espaços educativos. Nessa trajetória, como professor da Educação Infantil, foi possível observarmos diferentes práticas com crianças, a atuação pedagógica, os “olhares" sobre a infância e a criança, essa percepção nos motivou a propor essa investigação, inclusive no sentido de entender o nosso olhar e a nossa atuação como educador nos espaços educativos. Toda essa perspectiva apresentada nos faz uma provocação e nos movimenta no sentido do estudo das questões relacionadas com as representações sociais sobre infância e criança construídas e reconstruídas por professores nos espaços educativos dos Centros de Educação da Primeira Infância do Distrito Federal.

A Representação Social aqui se insere como teoria norteadora, pois ela 
é um conhecimento, socialmente elaborado e partilhado, com objetivo prático, e que contribui para a construção de uma realidade comum a um conjunto social. Igualmente designada como saber do senso comum ou ainda saber ingênuo, natural, esta forma de conhecimento é diferenciada, dentre outras, do conhecimento científico. (JODELET, 2001, p.22).

O estudo das Representações Sociais se apresenta neste contexto como um alicerce capaz de contribuir com as indagações apresentadas, na medida em que investiga justamente como se formam e como funcionam os sistemas de referência que utilizamos para classificar pessoas e grupos e para interpretar os acontecimentos da realidade cotidiana.

Por suas relações com a linguagem, com o construto social e o saber natural e, principalmente por seu papel na orientação de condutas e das práticas sociais, as representações sociais constituem elementos essenciais à análise dos mecanismos compõem a presente relatório, por sua abordagem, relevância, estrutura e organização, tendo em vista que se refere à compreensão do conjunto dos processos de construção de uma rede de significados sociais existentes e de sua manutenção.

Para Moscovici (2011, p. 40), as representações sociais são um conjunto de conceitos, afirmações e explicações sobre os eixos e os eventos que se originam no cotidiano, dentro de um curso de comunicação individual que são compartilhados pelos membros de um grupo social servindo para orientar no contexto social em que estão inseridos, para entendêlos e explicá-los. A partir do momento que estamos inseridos num ambiente onde acontecem trocas, ideias, formas de comportamentos, influências, não há como agir isoladamente, haverá necessariamente uma ação interativa complexa entre os sujeitos participantes desse meio, que é social e mais, haverá pensamentos, valores e atitudes produzidos previamente pela e na sociedade que orientará a ação do sujeito. Nesse sentido, o autor afirma que:

Nossas coletividades hoje não poderiam funcionar se não se criassem representações sociais baseadas no tronco das teorias e ideologias que elas transformam em realidades compartilhadas, relacionadas com as interações entre pessoas que então, passam a constituir uma categoria de fenômenos à parte. E a característica específica dessas representações é precisamente a de que elas "corporificam ideias" em experiências coletivas e interações em comportamento. (MOSCOVICI, 2011, p. 48).

Segundo Jodelet (2001), as representações sociais são modalidades de conhecimento prático, orientadas para a comunicação e para a compreensão do contexto social, material e ideativo em que indivíduo/grupo vive. Para essa autora, as 
representações sociais são, essencialmente, fenômenos sociais que têm que ser entendidos a partir do seu contexto de produção, funções simbólicas e ideológicas a que servem e pelas formas de comunicação onde circulam.

Portanto, cabe destacar que promover pesquisa no campo das representações sociais nos coloca frente a alguns obstáculos, pois requer um esforço para renunciar à compreensão do fenômeno social como uma atividade estagnada, rígida e sem movimento. Deve-se considerar o fenômeno ou o problema a ser investigado e delimitálo, observar a sua concretude e consistência. Verificar se há uma viabilidade metodológica para a sua realização e fundamentar teoricamente o objeto de pesquisa, pois mesmo sendo um estudo do universo consensual, o seu objeto de estudo encontrase no campo da ciência.

É nesse sentido que esse contexto teórico-metodológico ancorou esse estudo acerca das representações sociais de professores sobre infância e sobre criança em um espaço educativo, uma vez que, segundo Gilly (2001):

A área educacional aparece como um campo privilegiado para se observar como as representações sociais se constroem, evoluem e se transformam no interior dos grupos sociais, e para elucidar o papel dessas construções nas relações desses grupos com o objeto de sua representação. (GILLY, 2001, p. 322).

As concepções teóricas que dão suporte ao estudo da Infância imprimem novas formas de vê-la e entendê-la na sociedade e, principalmente, no espaço educativo. Portanto, se faz imprescindível trazer, também, como aporte teórico, a Sociologia da Infância que nos ajudará a desvelar, com mais precisão, o lugar que a infância ocupa nas atuações pedagógicas dos professores nos Centros de Educação da Primeira Infância CEPIs. A intenção aqui foi de construir possibilidades de identificação com o outro, nos caminhos que reforçam a hipótese de Corsaro (2011), quando nos diz que apenas com a institucionalização da escola é que o conceito de infância começa lentamente a ser alterado, através da escolarização das crianças. Podemos então, a partir do desenvolvimento de uma pedagogia para as crianças, falar em uma representação social da infância, sendo o professor o ator de mediação nesse desenvolvimento e partícipe desse construto.

Esta é a perspectiva adotada nesta pesquisa qualitativa, buscando seus fundamentos nas Representações Sociais, com uma relevância ímpar para repensar a "infância e criança" nos espaços educativos e a atuação pedagógica dos seus professores 
no cotidiano escolar. Nesse sentido, o estudo pretendeu responder a seguinte questão: Como se estruturam, se organizam e se ancoram as representações sociais dos professores dos CEPIs sobre infância e sobre criança?

Algumas subquestões foram elencadas para ajudar a responder a questão central, são elas:

1- Quais as representações sociais dos professores dos CEPIs sobre infância e sobre criança?

2- Quais os elementos do sistema central e sistema periférico do campo das representações sociais presentes nas representações dos professores dos CEPIs?

3- Como os elementos do núcleo central, presentes nas representações dos professores dos CEPIs, se manifestam no cotidiano pedagógico?

Segundo Gilly (2001), o estudo das representações sociais na educação permite identificar, em determinado grupo social, as suas atitudes, seus comportamentos, e maneira como são concebidos em um determinado espaço educativo.

Nesse sentido, para ajudar a responder as questões apresentadas, elencamos o objetivo geral para esse estudo: Analisar como se estruturam, se organizam e se ancoram as representações sociais dos professores dos CEPIs sobre infância e sobre criança.

Para possibilitar a investigação, desse objetivo geral, foram formulados os seguintes objetivos específicos:

1- Identificar as representações sociais dos professores dos CEPIs sobre infância e sobre criança.

2- Analisar os elementos do núcleo central e elementos periféricos do campo das representações sociais dos professores dos CEPIs.

3- Compreender como os elementos do núcleo central presentes nas representações dos professores dos CEPIs, se manifestam no cotidiano pedagógico.

Para alcançar esses objetivos, optando pela Teoria das Representações Sociais, admitimos que ela nos permitiu compreender como se estruturam, se organizam e em 
que se ancoram as representações sociais dos professores, suas ideias e conhecimentos sobre infância e criança e o cotidiano onde se desenvolvem, que nesse estudo foi a sua prática pedagógica. Possibilita-nos, também, identificar prováveis elementos dessas representações sociais durante a ação humana, partindo do pressuposto que "o comportamento dos sujeitos ou dos grupos não são determinados pelas características objetivas da situação, mas pela representação desta situação" (JODELET, 2001, p. 156).

Acreditamos que essa busca pôde contribuir para o campo da Educação, para os estudos sobre infância e criança na medida em que as temáticas tratadas (como esses sujeitos representam a infância e a criança) possibilitaram o entendimento da posição que a infância e criança assumem em espaços educativos a elas destinados.

Assim, para uma maior compreensão dos objetivos propostos, iniciaremos o capítulo a seguir discutindo infância e criança, marcando traços elencados pela historicidade que trazem esses elementos, bem como a construção social alicerçada nas contribuições contemporâneas, importantes para a fluidez desse estudo. 


\section{CAPÍTULO I}

\section{INFÂNCIA E CRIANÇA \\ Da incompletude social à (re) construção social do sujeito de direitos}

\section{1 - Infância}

A infância tem se estabelecido em campo de estudo de várias áreas do saber focada a partir de diferentes abordagens, enfoques e métodos, conforme são exemplos os trabalhos apresentados em obras como as de Ariès (1981), Corsaro (2011), Pinto e Sarmento (2004), Sirota (2001), Fernandes (1960), James e Prout (1997), Montadon (2005), Delgado e Müller (2005), entre tantos outros.

Observando sob a ótica histórica, a obra de Ariès (1981) retrata as imagens e concepções da infância no ocidente. Apesar das críticas de alguns autores em razão de sua perspectiva linear e por seus limites metodológicos, o autor, por meio da sua produção -“A História social da criança e da família" - aponta sinais que permitem acompanhar como a infância foi sendo percebida. Ariès (1981) pontua que a "aparição da infância" se deu a partir do século XVI e XVII na Europa Ocidental, especialmente na França, quando com o mercantilismo foi alterado tanto o sentido como as relações em torno da criança, conforme a estrutura social à qual faziam parte.

Ainda nesse entendimento, o referido autor fala ainda da ausência de sentimentos em relação à infância na antiguidade. Para ele esse modo de perceber as crianças sem singularidade e não separadas do mundo adulto, mostrava que elas eram consideradas adultos em miniatura.

A partir do século XVIII, começaram a ocorrer mudanças no interior das famílias, fazendo surgir o "sentimento de família", marcado por um desejo de privacidade. O modelo de família burguesa vem instituir modificações no contexto familiar, como a divisão e diferenciação de papéis sexuais: o homem passa a ser visto como o provedor, devendo, portanto, fazer parte do mundo público, e a mulher como a responsável pela casa e a educação dos filhos, atividades realizadas no mundo privado.

O alicerce social da infância, nos séculos XIX e XX, como etapa do desenvolvimento humano, fez advir a "infância científica", o que determinou por sua vez, um conjunto de teorias e práticas legitimadas no âmbito acadêmico que deveriam ser desenvolvidas para cuidar dessa fase. 
O trabalho de Ariès (1981) trouxe à tona a ideia de que a emergência do sentimento de infância, como uma consciência da particularidade infantil, é decorrente de um longo processo histórico, não sendo, portanto, uma herança natural. Isso trouxe grandes mudanças na compreensão da infância, já que, antes do século XVI, a consciência social não admite a existência autônoma da infância como uma categoria diferenciada do gênero humano. Na trajetória que fez, o autor demonstra que os séculos XVI e XVII esboçam uma concepção de infância centrada na inocência e na fragilidade infantil. Já o século XVIII inaugurou a construção da infância moderna, assumindo o signo de liberdade, autonomia e independência, mas foi no século XIX que o sentimento de infância se consolidou sob o signo da condição criança-aluno, ou seja, do sujeito escolar.

Portanto, na perspectiva de Ariès (1981), a infância como hoje conhecemos foi uma criação de um tempo histórico e de condições socioculturais determinadas, sendo um equívoco querermos analisar todas as infâncias e todas as crianças tomando-se o mesmo referencial. Partindo desse pressuposto, podemos, então, inferir que, se a infância muda com o tempo e com os diferentes contextos sociais, econômicos, geográficos, e até mesmo com as peculiaridades individuais, as crianças de hoje não são exatamente iguais às do século passado, nem serão idênticas às que virão nos próximos séculos. Assim, não podemos falar de infância, no singular, mas de infâncias.

Na perspectiva demográfica, Javeau (2005), refere-se à infância como geração, à faixa etária. A infância era considerada improdutiva, salvo pelas obrigações escolares, que, em certos países, são estendidas às idades inferiores com as creches e jardins de infância, respeitando-se os limites fixados pela lei. Contudo, para Sarmento (2004), este campo semântico reconceitualiza o conceito de geração historicizando-o "[...] sem perder de vista as dimensões estruturais e internacionais". Nessa perspectiva, ressalta-se que a conceitualização da infância, enquanto categoria geracional separada do adulto sustenta a preocupação em orientar as políticas públicas no sentido de garantir os direitos da infância e lhe propiciar melhores condições de vida.

Enquanto fase biológica, a concepção de infância está ligada ao discurso que compreende a infância como um período de transição no qual a criança está em processo de desenvolvimento e o objetivo final desse período consiste em atingir a maturidade na idade adulta. Essa concepção de infância esteve fortemente presente na sociologia clássica e atrelada aos conceitos de socialização. Tal afirmação pode ser observada no entendimento de socialização cunhado por Durkheim: 
[...] a sociedade se encontra, a cada nova geração, como que diante de uma tabula rasa, sobre a qual é preciso construir quase tudo de novo. É preciso que, pelos meios mais rápidos, ele agregue ao ser egoísta e associal, que acaba de nascer, uma natureza capaz de vida moral e social, eis aí a obra da educação. Ela cria no homem um ser novo (DURKHEIM, 1978, p. 42).

Nesse contexto, Corsaro (2011) nos diz que a sociologia, devido às visões tradicionais de socialização das crianças que as relegam a uma função essencialmente passiva, não prestava a devida atenção às crianças e à infância. $\mathrm{O}$ autor destaca o papel do construtivismo, nomeando Piaget como representante da teoria cognitiva de desenvolvimento e Vigotski, da abordagem sociocultural, que contestam o papel passivo da criança no processo de desenvolvimento, porém, elucida que:

[...] essas teorias até recentemente focalizaram principalmente $o$ desenvolvimento de resultados e falharam na consideração da complexidade da estrutura social e das atividades coletivas das crianças. (CORSARO, 2011, p. 40).

A infância, enquanto objeto de pesquisa, resultou da constatação de carências e fragmentação do objeto. Nesse sentido, podemos observar que sempre esteve presente nos métodos e instituições socializadoras uma análise sociológica, cujo objetivo principal era a idade adulta. Conforme afirma Sirota (2001), a sociologia em geral, e principalmente a sociologia da educação, esteve durante muito tempo limitada à concepção durkheimiana, daí a marginalização conceitual da infância nesse campo do conhecimento, que considerava a criança um receptáculo da vida adulta, um vir a ser. (SIROTA, 2001).

A referida autora considera ainda a necessidade de um afastamento da concepção de infância durkheimiana, pois, "trata-se de romper a cegueira das ciências sociais para acabar com o paradoxo da ausência das crianças na análise científica da dinâmica social com relação a seu ressurgimento nas práticas e no imaginário social" (SIROTA, 2001, p. 11). Opondo-se a essa concepção de infância, considerada como simples objeto passivo da socialização adulta propõe a configuração de uma sociologia da infância. Nas palavras de Demartini (2001, p. 3), "o desafio de levar a sério a criança, rompendo com a sociologia clássica".

Entretanto, é importante verificar também que a concepção de infância estava atrelada às concepções de sujeito social e de sociedade que em muito diferem das 
concepções contemporâneas. As concepções formuladas por Durkheim provêm de um tempo histórico no qual a sociedade era fundamentada pela tradição e pelo costume, representava um sistema homogêneo e unificado de valores e papeis sociais. "A sociedade era interpretada como uma totalidade, um conjunto coerente e organizado no qual o ator era o sistema". Nesse sentido, ao sujeito social restava apenas seguir os caminhos impostos pela coerção social, na medida em que o sujeito social em Durkheim nada mais era que um reprodutor da ordem estabelecida, de forma que o sucesso da socialização era interpretado como uma total identificação do sujeito com os valores societários.

Outros fatores aliados aos saberes científicos sobre infância contribuíram para a sua institucionalização na modernidade, dentre eles a institucionalização da escola pública, o sentimento de cuidado e proteção das famílias e a promoção da administração da infância, configurando uma infância global (SARMENTO, 2002).

A busca de significado para a infância tem se constituído assim em objeto de interesse de pesquisadores e estudiosos das mais diversas áreas, no mundo inteiro. São historiadores, antropólogos, sociólogos, psicólogos, educadores, dentre outros, evidenciando que estamos diante de um campo de natureza multidisciplinar e que, apesar das divergências em suas trajetórias de pesquisa, têm convergido para o fato de que a evolução do conceito de infância e de criança tem uma relação também com a forma como os aspectos econômico, histórico, cultural e político interferem nas relações sociais e na constituição dos significados e concepções de que nos apropriamos.

Portanto, a ideia de infância como categoria construída histórica e socialmente é fruto da dinâmica das relações sociais, nas quais a criança exerce papel ativo, de um ser social, com características próprias do contexto onde se insere, que, ao interagir com os outros, também produz e reproduz a cultura, portanto (re) produz a vida social.

As representações, portanto, sobre a criança e a infância não estão desconectadas nem da época, nem das referências que foram tomadas para sua construção. Isso reforça a tese de que cada época irá produzir seus discursos e revelar seus ideais e expectativas em torno das crianças, o que nos permite pensar que a infância é, portanto, uma construção social. Então, seguindo nessa perspectiva, o estudo em representações sociais poderá nos ajudar a identificar como os professores compreendem a infância, nos permitindo perceber se as representações corroboram com o entendimento proposto nas pesquisas da Sociologia da Infância e como essas representações se manifestam no seu cotidiano pedagógico. 


\section{2 - Criança}

A criança, quando nasce, se depara com um mundo novo e desconhecido, do qual precisa se apropriar durante o processo de socialização para se tornar parte integrante da sociedade e constituir um sujeito social, quando assume normas, valores, crenças, direitos e deveres, enfim, adquire uma identidade social (DUVEEN, 2013).

Ratificando o pensamento de Duveen (2013, p. 223), "Entre a sociedade pensante dos adultos e a emergência da criança enquanto ator social existe um processo de construção que merece ser entendido", consideramos bastante relevante entender que representações são assumidas ou que caminhos se desvelam no processo de construção social da infância emergidos nas representações sociais que as professoras dos CEPIs manifestam no cotidiano pedagógico.

Pode-se dizer que as crianças têm alcançado um lugar de notoriedade nos estudos sobre a infância. Pesquisadores da área da educação infantil procuram construir um entendimento cada vez mais amplo a respeito dessa faixa etária, projetando-se à prática de pesquisas que tenham como sujeito de interesse a criança. Tal interesse os tem levado a examinar e analisar os processos de constituição do conhecimento das próprias crianças e dos adultos, principalmente dos professores, sobre esses sujeitos concretos e reais em diferentes contextos, bem como suas culturas, suas capacidades intelectuais, criativas, estéticas, expressivas, emocionais, éticas, corporais e afetivas, constitutivas de suas infâncias (SARMENTO, 2002).

Nesse sentido, as crianças devem ser consideradas uma população ou um conjunto de populações com pleno direito (científico), com seus traços culturais, seus ritos, suas linguagens, suas 'imagens-ações' ou, menos preciso no tempo e no espaço, com suas estruturas e seus 'modelos de ações'. Corsaro (2011) esclarece que "as crianças começam a vida como seres sociais em uma rede social já definida e, através do desenvolvimento da comunicação e linguagem em interação com os outros, constroem seus mundos sociais".

Javeau (2005) nos auxilia a diferenciar cada termo. Com relação ao termo criança, o autor esclarece que '[...] construiu-se um objeto abstrato, a 'criança', destinado a passar por níveis diversos e sucessivos na aquisição de competências, cada um deles constituindo uma etapa na fabricação da personalidade dos indivíduos". O autor nos apresenta, assim, a uma concepção psicológica, à preocupação com o sujeito criança, em si, com suas características individuais, porém não distante do ser social. 
Portanto, a ideia da criança como "vir a ser" e "ser associal" estava atrelada às concepções de sociedade, sendo que, dado o poder de definição da tradição e do costume, a consciência coletiva moldava a consciência individual, restringindo o papel do ator social, o qual era concebido como sujeito devido à sua pouca atividade. Nesse contexto, a criança era compreendida como um ser que deveria ser controlado e domesticado pelos processos de socialização.

Corsaro (2011, p.17), com base nos estudos de Qvortrup (2005), afirma que "as crianças foram marginalizadas na sociologia devido a sua posição subordinada nas sociedades e às concepções teóricas de infância e socialização”. Tendo em vista que durante muito tempo as crianças eram vistas pelo adulto sob a perspectiva do que se tornariam no futuro e dessa forma não havia necessidade da sociologia estudá-las, levando em consideração seus desejos e necessidades de acordo com o seu ponto de vista e não a partir apenas da compreensão dos adultos. Como representantes de uma categoria geracional, as crianças e suas infâncias ganharam destaque nos estudos da Sociologia da Infância. Para que possamos compreender o status atribuído às crianças nos estudos da sociologia da infância, precisamos compreender de acordo com Corsaro (2011), dois aspectos centrais:

1- As crianças são agentes sociais e como tal, interagem com o mundo circundante, de forma ativa e criativa e enquanto recebem influências do mundo adulto, criam suas próprias culturas infantis.

2- A infância é uma forma estrutural que se configura como uma categoria composta por sujeitos de uma determinada faixa-etária. No entanto, para as crianças a infância é uma fase transitória, com uma duração de tempo, enquanto para os adultos, a infância é uma fase que não desaparece, apesar da transitoriedade de seus membros.

Quebrando o movimento da infância enquanto "tábula rasa", fazendo emergir uma concepção de sujeito ator na construção social (e hoje sujeito de direitos), a Sociologia da Infância veio alicerçar o lugar da criança como uma população singular, que se constitui como ator social, atuante na dinâmica da sociedade, perfeitamente possível de ser analisada dentro da sociologia, capaz de formular rituais e culturas próprias (culturas infantis) por meio de processos de socialização que não são, de modo algum, perpendiculares. 
Todos esses elementos designam a esse estudo, ancorado também na Sociologia da Infância, o desafio de afinar os instrumentos metodológicos que possibilitaram investigar as representações sociais sobre infância e criança nos CEPIs. É importante ressaltar que não se trata de uma pesquisa, a priori, "com crianças", como nos chama a Sociologia da Infância. Contudo, esse estudo nos ajuda a elucidar as "infâncias" e as "crianças" adormecidas nos adultos - professoras - participantes da pesquisa e as experiências por elas vividas, corroborando a compreensão desses fenômenos sociais latentes nos Centros de Educação da Primeira Infância.

O campo da sociologia da infância tem nos ensinado que as crianças são atores sociais porque interagem com as pessoas, com as instituições, reagem frente aos adultos e desenvolvem estratégias de luta para participar no mundo social. Mesmo assim, ainda é preciso estabelecer referenciais de análise que nos permitam apreciar estes atores sociais que nos colocam inúmeros desafios, principalmente nos espaços educativos destinados às crianças. Para Sarmento (2004, p.10) “as crianças são também seres sociais e, como tais, distribuem-se pelos diversos modos de estratificação social: a classe social, a etnia a que pertencem, a raça, o gênero, a região do globo onde vivem. Os diferentes espaços estruturais diferenciam profundamente as crianças”.

Sarmento e Pinto (1997) reconhecem a capacidade simbólica por parte das crianças e a constituição das suas representações e crenças em sistemas organizados, ou seja, em culturas. A identidade das crianças é também a identidade cultural, ou capacidade de constituírem culturas não totalmente redutíveis às culturas dos adultos. Todavia as crianças não produzem culturas num vazio social, assim como não têm completa autonomia no processo de socialização. Isso significa considerar que elas têm uma autonomia que é relativa, ou seja, as respostas e reações, os jogos sociodramáticos, as brincadeiras e as interpretações da realidade são também produtos das interações com adultos e crianças (DELGADO; MÜLLER, 2005).

Uma precaução atual, em estudos sobre a infância, incide em evitar os reducionismos de qualquer ordem. Assim como nos aponta James e Prout (1997), é preciso que a sociologia da infância não caia na ideia de que a infância é uma construção unicamente social para abandonar o reducionismo biológico e, dessa forma, substituí-lo pelo reducionismo sociológico. A criança deve ser vista como um ser completo, biopsicossocial. Portanto, é preciso intensificar a interdisciplinaridade dos estudos da infância, o que inclui segundo Delgado e Müller (2005, p. 352), “a psicologia crítica, na procura de um diálogo que explora pontos em comum e 
diferenças, bem como um envolvimento com as ciências médicas e biológicas". A seguir, tentaremos fazer essa interlocução sociológico/biológica que nos aponta a construção de um sujeito biopsicossocial.

\section{3 - Sociologia da Infância e as Teorias do Desenvolvimento: Possíveis relações}

As teorias do desenvolvimento, nas suas diferentes abordagens, buscam explicar os processos que definem o ser humano naquilo que se refere a seu comportamento ao longo da vida. Esses estudos distinguem-se pela abordagem, forma de entendimento do seu objeto de estudo e delimitação desse objeto.

O desenvolvimento humano é caracterizado como uma área de estudo que busca investigar e interpretar todas as relações entre os seres humanos e seus contextos de desenvolvimento, bem como todos os processos de mudança pelos quais o ser humano passa (PAPALIA; OLDS, 2000), além das estabilizações desde a concepção até a morte (BERGER, 2003). Desta forma, fica evidente que os estudiosos do desenvolvimento humano procuram não só conhecer e medir as modificações humanas ao longo da vida, mas também utilizar seu conhecimento para ajudar todas as pessoas a desenvolverem seu pleno potencial (BERGER, 2003).

Nesse sentido, a Psicologia do desenvolvimento se investe dos conhecimentos produzidos pelas teorias do desenvolvimento a fim de entender diferentes aspectos que emergem em uma determinada ocasião que caracterizam o ser humano. É importante ressaltar que ela não age em função do tempo, até porque o tempo por si só não é um elemento constitutivo de um comportamento, mas há uma preocupação em entender o que ocorre em termos de mudanças, transformações que constituem os sujeitos, em um dado momento (BIAGGIO, 2001).

Diferentes teorias do desenvolvimento humano propõem possibilidades para explicar, a partir dos modos de agir do sujeito, de que maneira a ação humana se constitui, seja na tentativa de mensurá-la, categorizá-la ou mesmo para tentar identificar mecanismos que podem servir de controle dessa ação. Isso significa que elas buscam estabelecer relações entre o que é manifestado pelo sujeito e o que pode ser a sua origem, na tentativa de explicar o porquê, como e quando determinadas situações ocorrem. Pode-se supor que a intenção seja a de buscar evidenciar as diferentes etapas do desenvolvimento para, talvez, assumir um tom preditivo do comportamento humano. 
Algumas dessas teorias, ao longo do tempo, foram se tornando muito bem aceitas socialmente e influenciaram sobremaneira a compreensão sobre $\mathrm{o}$ desenvolvimento humano e as situações interativas presentes nesse universo e, nessa perspectiva, muitos foram os aspectos das teorias dominantes da psicologia do desenvolvimento que contribuíram para os estudos sobre a socialização da infância (CORSARO, 2011).

Nesse sentido, podemos ratificar o entendimento de infância e criança como uma construção social, pois envolve um processo de interpretação e busca de conhecimento e entendimento de algo que sempre esteve presente na sociedade. A criança, o sujeito biológico, sempre existiu como parte do desenvolvimento humano. Contudo, diante da dinamicidade das relações humanas, é inegável o crescente interesse em compreender o comportamento e o desenvolvimento do homem e consequentemente buscar esclarecêlo, tanto numa dimensão específica do organismo como em sua trama de relações com o mundo. Podemos observar a interlocução de diferentes áreas do conhecimento ao buscarem, à sua maneira, possíveis explicações para esse tema ao elaborarem as suas teorias.

De acordo com William Corsaro (2011), os estudos sobre a sociologia da infância devem considerar a atividade coletiva das crianças, compreendendo que elas adquirem, compartilham e elaboram a cultura a partir das interações vivenciadas no ambiente em que atuam. Ao não identificar a relevância desses aspectos, o pesquisador corre o risco de obter uma visão superficial sobre o tema e restringir seus estudos aos aspectos individuais da criança, de forma isolada. Para ele, o olhar sobre a participação social da criança deve contemplar a comunidade, o interpessoal e o individual, considerando a temporalidade e a ligação existente entre todos esses fatores.

$\mathrm{O}$ autor afirma ainda que as crianças foram colocadas à margem da sociedade durante um período significativo da nossa história. Quando o sentimento de infância começou a aparecer na sociedade, tornou-se comum vincular a criança à ideia do vir a ser, ou associadas ao papel social da mulher, quando vinculadas à função materna. A ideia das crianças serem vistas/consideradas como pessoas que sentem, pensam, desejam é uma abordagem relativamente recente.

Atualmente existem vários meios que podem subsidiar a compreensão do sentimento de infância e criança, tais como jornais, registros, estatutos que funcionam como fontes de informação sobre o tema, além de explicitar o seu contexto social. Contudo, ainda devemos admitir a forte influência que as teorias do desenvolvimento 
exercem sobre os estudos sociais referentes à criança e à infância, tendo em vista a grande possibilidade de diálogo e a colaboração mútua para a produção do conhecimento que a interlocução dessas duas áreas do conhecimento podem produzir.

Para discutirmos a infância, como uma fase da vida, e a criança, o sujeito dessa fase, temos que compreender histórica e culturalmente como esses dois termos evoluíram até os dias atuais e, para tanto, entender quais a influências que as teorias do desenvolvimento tiveram nesse processo.

Ao observarmos as teorias tradicionais, elas apontam a socialização como um processo de adaptação das crianças na sociedade (CORSARO, 2011). Além dessa ideia, existem duas possibilidades relativas a esse processo de socialização da criança. Uma refere-se a um modelo determinista, e a outra, construtivista.

De acordo com a vertente determinista, a criança desempenha um papel passivo, em que prevalece a ação de ser cuidada, treinada e controlada para que possa seguir os passos da vida adulta conforme o esperado; esse processo ocorria essencialmente no âmbito familiar até que a escola se tornou também um espaço protagonizador dessas atividades, o que pode ser conferido em Ariès (1981).

O modelo determinista se subdivide em dois processos. O funcionalista, no qual prevalece a preparação das crianças para se enquadrarem e contribuírem para a ordem social, fortalecendo dessa maneira a ideia de moldar as crianças. E o reprodutivista, que pontua a manutenção da sociedade por meio da reprodução das desigualdades sociais e apoio à classe dominante.

Vale ressaltar que esses dois enfoques não consideram a atuação ativa das crianças, eles subestimam qualquer ação realizada por elas, não lhes permitindo a devida importância na organização social e no desenvolvimento intelectual, evidenciando, dessa maneira, a teoria comportamental como principal fomentadora desse pensamento (CORSARO, 2011, p.22).

Considerando o modelo construtivista, entendemos que as crianças "são participantes ativas na construção social da infância e na reprodução interpretativa de sua cultura compartilhada" (CORSARO, 2011, p.19) e apresenta os teóricos Piaget e Vigotski como os principais representantes dessa abordagem.

Esse modelo inovou com o caráter epistemológico em seus estudos sobre as crianças, associando-os a seus conhecimentos biológicos. Esse feito teve grande impacto no olhar direcionado às crianças, em relação a seu desenvolvimento e a sua 
consequente socialização por considerar que elas "percebem e organizam seu mundo de maneira qualitativamente diferente dos adultos" (CORSARO, 2011, p.23).

Para Piaget, o desenvolvimento é um processo de adaptação ao meio social, em que o foco está nas estruturas cognitivas organizadas em esquemas. O esquema "geralmente inclui diferentes atos, em muitas circunstâncias diferentes, e não apenas uma resposta a um estímulo específico" (BALDWIN, 1973, p.162). Esses esquemas, ao longo do tempo, tornam-se cada vez mais complexos e podem ser compreendidos a partir da assimilação e da acomodação, que são dois conceitos que se complementam.

A assimilação corresponde à capacidade de um organismo para enfrentar novos obstáculos - ou situações, ou problemas - de acordo com os seus mecanismos atuais, e a acomodação refere-se à mudança que esse organismo sofre para adaptar-se. Nesse caso, o organismo deve assimilar uma nova situação antes de acomodá-la.

A estruturação desse processo de desenvolvimento ocorre em etapas, divididas em quatro períodos: a primeira é a infância - sensório-motor -, a segunda, préoperacional, a terceira são as operações concretas, e a última, as operações formais. A maturação desempenha um papel importante para o desencadeamento harmonioso desse processo, que se torna gradativamente mais intricado em seu funcionamento (BALDWIN, 1973). Ainda em relação a essa concepção de desenvolvimento, vale lembrar que, apesar de estar vinculada a um processo adaptativo, ela não se restringe a um aspecto fisiológico e/ou biológico, mas, sobretudo a uma natureza cognitiva de aprendizagem.

Essa abordagem cognitiva veio ao encontro às influências produzidas pelas teorias do desenvolvimento então difundidas socialmente, de modo particular nas instituições escolares. Esses ambientes tinham a firme missão de investir em um processo de ensino-aprendizagem pautado na ideia de os alunos estarem preparados para serem instruídos pelos seus professores desde sua mais tenra idade.

Essa ideia de que o conhecimento advém da experiência evidencia o pensamento de que o homem é o produto do meio (MIZUKAMI, 1986). Por isso, toda atividade voltada para a aprendizagem, principalmente para as crianças, nessa acepção, tem por base a transmissão do conhecimento e deve ser planejada visando ao controle de todo o processo e, ainda, com a garantia de predição de resultados ou alcance do comportamento esperado/idealizado. Nessa realidade, era desconsiderada a subjetividade do sujeito como ser que interage, sente e atua de forma consciente. Também não se leva em consideração o fato de que sua relação com - e no - mundo, 
tanto como sua relação com o outro, com o seu par, poderia ser frutífera para sua aprendizagem.

Outra teoria que marcou presença no início do século XX, cujos vestígios ainda podemos encontrar na atualidade, sobretudo quando adentramos o universo dos diagnósticos que buscam explicar as dificuldades de aprendizagem, diz respeito à Psicologia Experimental, notadamente representada por Binet. Ele nos deixou o legado da psicometria e seus instrumentos para mensurar a inteligência. Essa teoria contribuiu efetivamente para a construção daquilo que poderia ser considerado excepcional, desviante ou normal (GOULART, 1999).

Consequentemente, também essa teoria colaborou de forma significativa para o estabelecimento daquilo que é considerado regular e aceitável socialmente em termos de comportamento humano, criando a noção de aptidão do homem para a realização de diferentes tarefas e legitimando expressivamente o processo de exclusão, como se não houvesse outros fatores que implicassem no processo de aprendizagem do ser humano. Devemos considerar que, às vezes, um entrave à aprendizagem não se refere a uma não capacidade cognitiva, ela pode ser de cunho emocional, ou relacional, por exemplo.

Ainda em relação às teorias existentes e difundidas, o que se percebe é que, apesar de encontrarmos abordagens teóricas que apregoam o ensino centrado no aluno, no sentido de considerar a criança um ser que tem capacidade de pensar, criar e de se organizar, à semelhança do que Rogers anunciou em sua abordagem humanista, é difícil até mesmo vislumbrá-las em nossa realidade educacional. De certa forma, isso nos chama a atenção porque se uma escola utilizasse essa perspectiva, poderia, talvez, considerar o próprio aluno como fonte de informação. Com isso, queremos sugerir que muitos ganhos haveria para a prática educativa se o professor estivesse em contato com seus alunos e consequentemente atento ao conteúdo de história de vida que eles levam para a escola, também ao que fazem e àquilo que dizem. Outro aspecto que consideramos importante é referente à existência dessas diferentes abordagens teóricas sobre o desenvolvimento: por que algumas possuem mais adesão social que outras? Isso é visível nas instituições escolares.

Acreditamos que talvez as responsáveis pela credibilidade dada a essas teorias sejam as inúmeras explicações e formulação de hipóteses específicas que elas apontam para explicar o modo como o ser humano se desenvolve. Aparentemente quanto mais amparados forem os argumentos e suas demonstrações práticas, maior o sentimento de segurança que uma teoria pode vir a proporcionar, principalmente nas situações que 
estabelecem uma relação direta de causa e efeito para as ações humanas. Esse foi, o que é bem evidente, um grande legado do pensamento positivista/empirista, muito bem aplicado e executado em diferentes áreas do conhecimento. Provavelmente os problemas que resultam desse modelo de pensamento e interpretação do mundo estejam associados a uma utilização inadequada de seus argumentos nas áreas que buscam entender o comportamento e desenvolvimento humano.

Vigotski, por sua vez, apresenta em sua teoria o componente cultural e o processo de socialização com outras pessoas como elementos essenciais para o entendimento do desenvolvimento humano, explicitando que ele ocorre inicialmente no meio social para, a partir daí, acontecer individualmente - parte das situações interpessoais para o campo intrapessoal (OLIVEIRA, 2010).

Para compreender a construção do pensamento como um processo de natureza sociocultural, o autor traz a linguagem como produtora desse pensamento e cria o conceito de Zona de Desenvolvimento Proximal - ZDP para explicar como ele acontece. Para ele, "o mundo não é visto simplesmente em cor e forma, mas também como um mundo com sentido e significado" (VIGOTSKI, 2008, p.24). Baseando-se nessa premissa, o homem extrapola a situação de utilização daquilo que é sensorial para desenvolver-se por meio dos instrumentos e de seus significados.

As teorias de Vigotski, de um modo geral, seus postulados têm como foco os sujeitos que aprendem, o modo como eles funcionam enquanto indivíduos, considerando os aspectos sociais, políticos, culturais que compõe uma sociedade. Outras teorias do desenvolvimento não pretenderam adentrar nas questões sociais, no cotidiano, como ponto importante para a constituição dos sujeitos como integrantes de uma sociedade que possui uma dinâmica que extrapola o viés teórico do desenvolvimento focado no indivíduo. Assim, Vigotski (2008), ao considerar o meio social, a mediação, a interação com o outro como elementos fundantes do processo de desenvolvimento e aprendizagem dos sujeitos desde o seu nascimento, se torna um dos autores mais influentes da atualidade que incorporam não somente os discursos mas, sobretudo, o fazer pedagógico. 


\section{4 - Olhares contemporâneos sobre a infância e a criança}

James e Prout (1997) deixam clara uma posição - a infância é uma instituição social, um conjunto de relações sociais ativamente negociadas através das quais os primeiros anos da vida humana são constituídos. O paradigma apontado pelos autores está intimamente relacionado com a "dupla hermenêutica" das Ciências Sociais implicando a reconstrução da infância a um patamar científico e a transformação das práticas profissionais e metodológicas que se unem com esta nova visão da criança.

Uma proposta metodológica e teórica de investigação e identificação da emergência de um novo paradigma para o estudo social da infância é apresentada pelos autores. Nessa perspectiva, dois aspectos são apontados: A existência de um paradigma mais como potencial ou possibilidade; os fundamentos são de importância vital e prioritária para o desenvolvimento de uma nova fase na investigação sobre infância. James e Prout (1997) defendem, para uma reconstrução da infância, que este paradigma deve assentar nos seguintes princípios:

1. A infância deve ser entendida enquanto uma construção social, ou seja, a infância, distinta da imaturidade biológica, não é nem uma característica natural nem uma característica universal dos grupos humanos, mas sim um componente estrutural e cultural de muitas sociedades.

2. A infância é uma variável susceptível de análise social. Nunca pode ser inteiramente separada das outras variáveis sociais como classe, gênero ou etnia, o que origina não uma, mas uma grande variedade de infâncias.

3. As relações sociais das crianças e as suas culturas são dignas de estudo por si mesmas, independentemente das perspectivas e interesses dos adultos. 4. As crianças são e devem ser vistas como seres ativos na construção e determinação das suas próprias vidas, das vidas dos que as rodeiam e da sociedade em que vivem.

5. Permitir à criança ter voz e participação mais direta na produção dos dados sociológicos.

Assim, segundo estes princípios, os autores consideram a criança como ator social, assim a criança não se limita a esgotar ou absorver a cultura adulta já constituída, mas exerce nela transformações pela forma como a interpreta e integra, e pelos efeitos que gera a partir das suas práticas. 
Enquanto os adultos podem reconhecer as crianças como atores sociais com seus próprios interesses, motivações, desejos e opiniões, James e Prout (1997) argumentam que em tempos de controvérsia e incerteza, especialistas em cuidados infantis, incluindo, dentre outros, professores, tendem a desenhar estereótipos normativos de crianças como irracional, ignorante e incompleta.

Para James e Prout (1997), a construção científica da irracionalidade, naturalidade e universalidade da infância presente, inclusive, no discurso psicológico foi diretamente transferida, durante os anos 1950, para o campo do conhecimento sociológico da infância na forma das "teorias da socialização". A compreensão estrutural funcionalista dominante no pensamento sociológico da época previa para o indivíduo um número finito de "papeis sociais". Assim, a socialização era entendida como o mecanismo pelo qual esses papeis podiam ser reproduzidos em sucessivas gerações. Socialização era, portanto, o processo através do qual um ser era "magicamente", na expressão dos autores, transformado em outro: a chave pela qual a criança a-social se convertia num adulto socializado.

Por fim, em face da natureza do objeto dessa proposta de estudo, bem como da perspectiva teórica adotada, esta pesquisa orientou-se pela abordagem qualitativa, com o intuito de buscar suas conclusões na análise do conteúdo para ser utilizada no processo de análise das informações levantadas nos grupos focais e nas observações, pois esses procedimentos ajudaram a classificar os elementos ou aspectos com características comuns ou com relação entre si, a fim de apreender as representações sociais que as professoras dos Centros de Educação da Primeira Infância constroem sobre infância e criança. Também pela própria natureza do estudo, a análise, a que foram submetidas as informações coletadas se assentou numa fundamentação de cunho psicossociológico.

Portanto, a análise na perspectiva assumida no estudo, tem seus sentidos estruturados nos diálogos dos múltiplos conhecimentos individuais, ditos subjetivos, construídos a partir dos costumes, das crenças, dos valores e das tradições que circulam nas trocas de informações, experiências e relações do cotidiano dos professores que atuam nos Centros de Educação da Primeira Infância, pretendendo elucidar assim as representações sociais que se manifestam no cotidiano pedagógico, representações estas que traremos no bojo da teoria das Representações Sociais, anunciadas no próximo capítulo. 


\section{CAPÍTULO II}

\section{A TEORIA DAS REPRESENTAÇÕES SOCIAIS.}

A Teoria das Representações Sociais - TRS tem um enfoque predominante na psicologia social. Para Moscovici (2011), a Representação Social é uma modalidade particular do conhecimento, cuja função é a elaboração dos comportamentos e a comunicação entre os indivíduos. Tal representação é um corpo organizado de conhecimentos e uma atividade cíclica com as quais os sujeitos se integram em grupos ou em relações cotidianas.

A investigação de Moscovici buscava estudar os processos de penetração social na sociedade francesa dos anos 50, por não distinguir dois processos básicos que explicam como o social transforma um conhecimento em representação coletiva e como esta modifica o social. O autor da Teoria das Representações Sociais pretende escrever um modelo explicativo de gênese da troca social, pois seu foco de interesse não está no processo de troca da minoria como consequência de uma aparição majoritária se não em um processo complementar. Trata-se de uma Psicologia Social das minorias ativas que se interessam pelos processos psicossociais vinculados à inovação e à expansão de novas ideias na sociedade e como esta pode acabar aceitando movimentos provenientes de grupos sociais minoritários. Moscovici (2011) nos fala aqui das ideias de uma sociedade política e cultural, artística ou científica cuja novidade desafia um princípio estabelecido que acabasse convencendo a um número suficiente de sujeitos sociais para se transformar em um pensamento majoritário.

Moscovici (2011) aponta que as representações sociais são um conjunto de conceitos, afirmações e explicações sobre os eixos e os eventos que se originam no cotidiano, dentro de um curso de comunicação individual que são compartilhados pelos membros de um grupo social servindo para orientar em um contexto social, para entendê-los e explicá-los.

A importância dialética desse construto social por meio das Representações Sociais sobre infância e criança, em um entendimento mais amplo, reconhece a estreita ligação entre o universo consensual onde estão ancorados alguns saberes dos professores e o universo reificado onde se alicerçam as teorias bases da prática pedagógica. Propor uma análise nessa perspectiva é um exercício de pesquisa 
imprescindível àqueles que acreditam no caráter de mudança significativa intrínseco ao processo de construção das práticas pedagógicas.

Optar pela Teoria das Representações Sociais é admitir corroborar a gênese de um dos pensamentos gerais dessa teoria: o significado que alguém atribui a um dado objeto é uma construção psicossocial (MOSCOVICI, 2011).

Por construção psicossocial, Jodelet (2001) considera que as representações sociais têm seu princípio nas relações sociais, especialmente nas que envolvem a comunicação verbal, relações essas que colaboram para a construção de realidades compartilhadas por um determinado grupo social. Esta autora explica que as representações sociais têm sido objeto de estudo de distintas áreas de conhecimento, tendo em vista sua importância heurística para a explicação dos processos cognitivos e da ação destes no âmbito das interações sociais. Ou seja, as representações sociais são, ao mesmo tempo, produto e processo de uma atividade de apropriação da realidade exterior ao pensamento e de elaboração psicológica e social dessa realidade (DOTTA, 2006).

Em função da dupla natureza das representações sociais, social e psicológica, uma preocupação apresentada por Jodelet é a possibilidade de redução das representações a fatores intra-individuais, onde o fenômeno social é entendido como uma intervenção secundária, ou como uma forma diluída em fenômenos culturais (JODELET, 2001). A partir do paradoxo observado entre as explicações apresentadas pelo individualismo norte-americano e pela sociologia, Moscovici (2011) considera que a noção de representações sociais é de difícil compreensão devido à sua complexidade. Jodelet (2001), na tentativa de achar um ponto de consenso no campo, o define como "uma forma de conhecimento, socialmente elaborada e partilhada, que tem um objetivo prático e concorre para a construção de uma realidade comum a um conjunto social" (JODELET, 2001). Por essa definição pode ser percebida a complexidade existente na conceituação do campo.

Para a compreensão desse processo cognitivo no âmbito das interações sociais e do movimento simbólico, nos espaços educativos especificamente, Gilly (2001) assinala a importância da noção de representação social, com a premissa de que ela “orienta a atenção para o papel de conjuntos organizados de significações sociais no processo educativo" (GILLY, 2001, p. 321), auxiliando a compreender fenômenos macroscópicos. No Brasil, trabalhos como os de Alves-Mazzotti (2008) e Madeira 
(2001) também têm evidenciado a importância da teoria das representações sociais para a Educação.

No campo educativo, Gilly inclui que este:

[...] aparece como um campo privilegiado para verificar como se constroem, evoluem e transformam as representações sociais no interior dos grupos sociais, e esclarece sobre o papel dessas construções nas relações desses grupos com o objeto de sua representação. A representação como conjunto organizado de significações sociais permite uma nova via para a explicação dos mecanismos por meio dos quais fatores propriamente sociais agem sobre o processo educativo e influenciam resultados. (GILLY, 1984, p. 364 IN ORNELLAS, 2005, p. 38).

Gilly (2001) afirma que a área educacional é um campo ótimo para a observação de como as representações sociais se constroem, evoluem e se transformam dentro dos grupos sociais e de como essas construções se relacionam entre os grupos e o objeto da representação. São inúmeros os trabalhos nessa área que abordam as representações de professores sobre sua própria profissão (CASTRO, 2002; COSTA e ALMEIDA, 2000; DOTTA, 2006; LOUREIRO, 2003; VERÍSSIMO e ANDRADE, 2001; VILLELA, PRADO e TURA, 2002). Entretanto, faltam estudos mais específicos acerca das representações sociais sobre infância e criança (foi identificado um estudo de DEMATHÉ e CORDEIRO (2007) tratando da representação de professoras sobre infância) e, principalmente em relação às práticas educativas utilizadas com a mesma e a interação com esses sujeitos (DUVEEN, 2013; GILLY, 2001; OLIVEIRA, 2010; CASTRO, 2011). Assim, estudos realizados com esta perspectiva têm muito a contribuir na busca do conhecimento de novas representações e no desenvolvimento teórico-metodológico do próprio campo educativo e, principalmente, para formação e desenvolvimento da criança, considerando que as representações sociais de um grupo sobre um determinado objeto se constituem em elementos explicativos e prescritivos da própria realidade social deste grupo. (ABRIC, 2003).

\section{1- O movimento multifacetado das representações sociais: Dinâmicas}

Tão importante quanto alinhavar o conceito de Representações Sociais é também compreender os processos que as geram. De acordo com Moscovici (2011), existem na sociedade dois tipos de universos de pensamento - o universo consensual e o universo reificado. Explicar esse movimento se faz imprescindível para entendermos os 
processos de construção das representações sociais que são materializadas pelos professores dos Centros de Educação da Primeira Infância, tanto no sentido da concepção do senso comum, emergido em seus espaços sociais (do universo consensual), como no conhecimento adquirido na sua formação docente (do universo reificado). O primeiro encontra-se nas práticas interativas cotidianas, nas quais se constroem as representações sociais. Já o segundo é o mundo das ciências, da objetividade e das teorizações abstratas. É nesse espaço onde se produz, na maioria das vezes, o que não nos é familiar, que é incorporado ao universo consensual através das representações sociais, tornando-se assim familiar. Essa passagem de um objeto do universo científico para o universo consensual se dá através de dois processos: a objetivação e a ancoragem.

A ancoragem é o processo que precede a objetivação e refere-se ao movimento pelo qual o não-familiar se torna familiar. Ele é o processo responsável por transformar tudo aquilo que nos aparece como perturbador, como estranho e distante, em algo conhecido. É através dele que o diferente se une a algo já conhecido e significativo. Ou seja, é unir o diferente a alguma coisa já conhecida, significada. Segundo Sá (1993), a ancoragem

consiste na integração cognitiva do objeto representado (sejam ideias, pessoas, acontecimentos, relações) a um sistema de pensamento social preexistente e, consequentemente, nas transformações implicadas. [...] Este processo é responsável pelo enraizamento das ideias. Ancoragem é, portanto, classificação e denominação. (SÁ, 1993, p.34).

A ancoragem, portanto, compõe um novo conceito a esquemas, ideias e acontecimentos preexistentes na medida em que traz para categorias e imagens conhecidas aquilo que ainda não está classificado e busca um paradigma que possa estabelecer uma comparação com o objeto a ser representado, incorporando a ele novos elementos (SÁ, 1993). Assim, na ancoragem, através da classificação e da nomeação, damos um sentido a algo que não nos era familiar o que faz com que o indivíduo tornese capaz de imaginá-lo e de representá-lo. Portanto, ao ancorar o seu pensamento, o indivíduo passa a objetivá-lo.

A objetivação consiste no processo de naturalização, de concretização das noções e dos conceitos abstratos de uma realidade, que se transformam em elementos evidentes e simples. Assim, ao concretizar-se, essa nova informação torna-se real e natural num grupo social. Ela tem como função dar materialidade a um objeto abstrato, reproduzindo um conceito em uma imagem. Segundo Sá (1993, p. 47), “é uma operação 
imaginante e estruturante, pela qual se dá uma forma (ou figura) especifica ao conhecimento acerca do objeto, tornando-o concreto, quase tangível, o conceito abstrato, materializando a palavra".

Para Alves-Mazzotti (2008, p.28), a objetivação pode ser definida "como a passagem de conceitos ou ideias para esquemas ou imagens concretas, os quais, pela generalidade de seu emprego, se transformam em supostos reflexos do real". Para essa autora ainda, nesse processo de objetivação

[...] as informações que circulam sobre o objeto sofrem uma triagem em função de condicionantes culturais (acesso a diferenciado às informações em decorrência da inserção social do sujeito) e, sobretudo, de critérios normativos (guiados pelo sistema de valores do grupo) de modo a proporcionar uma imagem coerente e facilmente exprimível do objeto da representação. (ALVES-MAZZOTTI, 2008, p. 60).

Esta fase, segundo Jodelet (2001), está associada ao "processo psíquico interno pelo qual o indivíduo procura tornar um fato, objeto e/ou conhecimento novo, em algo familiar coerente com o referencial que já traz consigo, e para isso, forja uma visão do objeto que seja coerente com sua visão de mundo." A terceira fase corresponde às figuras e elementos do pensamento que se convertem em certos elementos da realidade, adquirindo status de destaque. É esta fase que permite o indivíduo materializar os elementos das ciências em elementos da sua realidade de senso-comum.

Nessas palavras dos citados autores, observamos que a objetivação trata, portanto, da concretização do processo de familiarização de um objeto. De modo mais simples, poderíamos dizer que é a transformação da realidade em imagem. Nesta direção, podemos inferir que objetivar é dar substância a um objeto aparentemente vazio na medida em que transforma o abstrato em algo quase palpável.

Sendo, consequentemente, a ancoragem e objetivação processos constitutivos das representações sociais, podemos então dizer que há uma relação de reciprocidade entre os universos consensuais e reificados, pois assim como o senso comum afeta a ciência, esta por sua vez também afeta o senso comum, estando esses universos dialeticamente relacionados.

As representações sociais também são constituídas de dois pólos indissociáveis: a figura, que diz respeito ao objeto ou fenômeno do mundo social e a significação que corresponde ao valor ou significado que o sujeito dá a essa figura ou 
imagem. Assim, ao ser representado, esse objeto ou fenômeno passa por um processo de reconstituição e modificação e esse processo de representação do objeto é diferente do próprio objeto. No momento em que esse objeto é representado, ele recebe um significado, um status de um signo (MOSCOVICI, 2011). Por essa razão, a representação implica numa reconstrução e não apenas numa reprodução, pois representar alguma coisa é reconstituí-la à nossa maneira e esse processo de recriação envolve uma dinâmica de familiarização, na qual os objetos e indivíduos sociais são percebidos, compreendidos e reconstruídos em relação aos conhecimentos prévios.

Corroborando as ideias de Moscovici, Sá (1993) afirma que uma das funções das representações sociais é a de nortear os comportamentos e as práticas humanas, e amplia essa discussão, com base nos estudos de Abric (2003), apresentando assim as quatro funções essenciais das representações, quais sejam:

1. Funções de saber, as quais permitem compreender e explicar a realidade e estabelecer a comunicação social. Elas definem o quadro de referência comum que permite a troca social, a transmissão e a difusão desse saber ingênuo.

2. Funções identitárias que definem a identidade social e pessoal compatíveis com os sistemas de normas e de valores social e historicamente determinados, permitindo assim a salvaguarda da especificidade dos grupos.

3. Funções de orientação as quais guiam os comportamentos e as práticas, definindo o que é lícito, tolerável ou inaceitável em um dado contexto social.

4. Função justificatória que permitem justificar a posteriori as tomadas de posição e os comportamentos.

Para serem disseminadas na vida cotidiana as representações sociais usam como via os discursos das pessoas e dos grupos, bem como comportamentos e práticas sociais onde esses discursos se revelam. Além disso, elas também transitam através das formas institucionais de registro dos discursos e práticas, assim como por meio das interpretações que recebem nos meios de comunicação de massa. Assim, a comunicação social desempenha um papel fundamental nas trocas e interações que concorrem para a criação de um universo consensual. Corroborando esse pensamento, Jodelet (2001, p. 
17-18), diz que as representações sociais "circulam nos discursos, são trazidas pelas palavras e veiculadas nas imagens midiáticas, cristalizadas em condutas e em organizações materiais e espaciais". Acrescenta ainda que a incidência da comunicação é examinada por Moscovici (2011) em três níveis:

1- O nível da emergência das representações sociais cujas condições afetam os aspectos cognitivos. Dentre essas condições, encontram-se: a dispersão e a defasagem das informações relativas ao objeto representado e que são desigualmente acessíveis de acordo com os grupos; o foco sobre certos aspectos do objeto, em função dos interesses e da implicação dos sujeitos; a pressão à inferência referente à necessidade de agir, de tomar posição ou de obter o reconhecimento e a adesão dos outros - elementos que vão diferenciar o pensamento natural em suas operações, sua lógica e seu estilo.

2- O nível dos processos de formação das representações, a objetivação e a ancoragem que explicam a interdependência entre atividade cognitiva e suas condições sociais de exercício, nos planos da organização dos conteúdos, das significações e da utilidade que lhes são conferidas.

3- O nível das dimensões das representações relacionadas à edificação da conduta: opinião, atitude e estereótipo, sobre os quais intervêm os sistemas de comunicação midiáticos. Estes, segundo pesquisas dos efeitos sobre sua audiência, têm propriedades estruturais diferentes, correspondentes à difusão, à propagação e à propaganda. A difusão é relacionada com a formação das opiniões; a propagação com a formação das atitudes e a propaganda com a dos estereótipos. (JODELET, 2001, p. $30)$.

Quanto à estrutura das representações sociais, Moscovici (2011) explica que esta se configura ao longo de três dimensões articuladas: a informação que se refere à organização dos conhecimentos que um grupo possui a respeito de um objeto social; o campo da representação que remete à ideia de imagem, de modelo social, ao conteúdo concreto e limitado das proposições acerca de um aspecto preciso do objeto da representação; a atitude que termina por focalizar a orientação global em relação ao 
objeto da representação social. Para esse teórico, essas três dimensões fornecem uma visão de seu conteúdo e sentido, entretanto ele confere uma maior importância à dimensão da atitude por considerá-la a mais frequente das três dimensões, e talvez, genericamente, a primeira, pois parte do pressuposto de que "as pessoas se informam e representam alguma coisa somente depois de terem tomado uma posição e em função da posição tomada. (MOSCOVICI, 2011, p. 32)".

A ênfase igualmente dada pela vertente de Moscovici ao social e ao individual põe em evidência que a teoria das representações sociais considera tanto os comportamentos individuais como os fatos sociais em sua concretude e especificidades históricas na medida em que o social deixa de aparecer apenas num segundo plano para assumir papel determinante na construção das mesmas. O "chão" das Representações Sociais é, portanto, a interação social, espaço onde ocorrem as relações com os outros e sua construção tem por base materiais de origens diversas como as referências históricas e culturais que constituem a sociedade ao longo de sua história.

Nessa perspectiva, podemos dizer que a produção de sentidos, na edificação das representações sociais, também não se dá de forma aleatória e nem funciona livre das influências sociais, pois o sentido é um projeto coletivo, construído com os esforços dos conhecimentos subjetivos, objetivados pelos interesses de um grupo, historicamente instituído.

Neste sentido, é que esta pesquisa se inseriu na vertente moscoviciana das representações sociais, voltando o seu olhar para os determinantes psicossociais que orientam os sujeitos nos seus julgamentos sobre o que seja infância e criança na perspectiva dos professores dos Centros de Educação da Primeira Infância. Assim, o modo como os sujeitos da pesquisa compreendem infância e criança é aqui entendido como uma ação social que pode variar no tempo e no espaço, à medida que novas informações, novas demandas de práticas educativas e novos valores culturais são incorporados ao contexto desses sujeitos.

Assim, ao tomarmos as representações sociais como aporte para esse estudo trataremos, portanto, de algo subjetivo e imaginado. E é nesse subjetivo que se instaura em relação à "infância e criança”, que buscaremos o que está subjacente no olhar do professor da primeira infância, pois é por intermédio das representações sociais que um grupo se expressa, definindo, com base em suas crenças e valores, diversas perspectivas de um determinado objeto, estabelecendo relações entre si que estão carregadas de significados. 


\section{2- Abordagem estrutural das representações sociais}

Para a investigação no campo educativo dos Centros de Educação da Primeira Infância, como aporte teórico-metodológico, este estudo adotou, também, a abordagem estrutural proposta por Jean-Claude Abric, no campo da Teoria das Representações Sociais. A concepção deste autor apoia-se na premissa de que as representações sociais estão estruturadas em torno de um núcleo, considerado seu elemento fundante, o qual informa parte da significação e da organização interna de uma dada representação social. Nesse sentido, o estudo, pretendeu, dentre outros objetivos já apresentados, analisar os elementos do núcleo central e elementos periféricos do campo das representações sociais dos professores dos CEPIs acerca de "infância e criança".

Abric (2003, p.27) entende que toda a realidade "é representada e reapropriada pelo indivíduo ou pelo grupo, reconstruída no seu sistema cognitivo, integrada no seu sistema de valores, dependente de sua história e do contexto social e ideológico que o cerca" (Grifo meu). Prossegue afirmando que "a representação não é um simples reflexo da realidade, ela é uma organização significante, é uma forma global e unitária de um objeto, mas também de um sujeito" (ABRIC, 2003, p.28).

Segundo Abric, esse duplo sistema, central e periférico, desempenham características e funções que são diferentes. No núcleo central podem ser identificadas as manifestações do pensamento social, necessárias para garantir a identidade e permanência em um grupo social. Essas reúnem crenças, coletivamente produzidas e historicamente situadas, as quais não são facilmente negociáveis, ou seja, constituem o fundamento dos modos de vida e do sistema de valores desse grupo (ABRIC, 2003). Os elementos que compõem o núcleo central são os mais estáveis da representação social e os mais resistentes a mudanças.

Abric (2003) considera o sistema periférico mais flexível do que o sistema central, sendo a parte acessível da representação social. Por seus elementos estarem relacionados ao contexto mais imediato e à história estrutural do indivíduo, o sistema periférico é constituído por elementos passíveis de mudanças, permitindo a adaptação do indivíduo a mudanças de conjuntura.

Dito de outra forma, Abric (2003) propõe que os elementos da representação social sejam organizados em um núcleo central, no qual toda a representação social é organizada e unificada, dando sentido ao conjunto das representações. Contudo, em volta desse núcleo, os elementos periféricos contribuem para clarear o caminho 
conceitual, teórico e metodológico do estudo das representações sociais de um determinado campo. Portanto, o que determina os elementos que constituem esse núcleo central depende da natureza do objeto de representação e da relação que o sujeito social mantém com o mesmo. Essas características foram elencadas por Abric (2003) no quadro 1:

Quadro 1. Características do núcleo central e elementos periféricos das representações sociais (adaptado do texto de ABRIC, 2003).

\begin{tabular}{|c|c|}
\hline Sistema Central & Sistema Periférico \\
\hline $\begin{array}{c}\text { Relacionado com a memória coletiva e a } \\
\text { história do grupo. }\end{array}$ & $\begin{array}{c}\text { Permite a integração de experiências e } \\
\text { histórias individuais. }\end{array}$ \\
\hline $\begin{array}{c}\text { Consensual - define a homogeneidade do } \\
\text { grupo. }\end{array}$ & \begin{tabular}{c} 
Suporta a heterogeneidade do grupo. \\
\hline Estável, coerente e rígido.
\end{tabular} \\
\hline Não muito sensível ao contexto. & Slexível, gera contradições. \\
\hline $\begin{array}{c}\text { Funções: gerar o significado da } \\
\text { representação; determinar sua } \\
\text { organização. }\end{array}$ & $\begin{array}{c}\text { Funções: permitir adaptação à realidade } \\
\text { concreta; permitir diferenciação do } \\
\text { conteúdo; proteger os elementos do } \\
\text { núcleo central. }\end{array}$ \\
\hline
\end{tabular}

Fonte: adaptação por Adail Santos, 2015.

Sem a pretensão de esgotar o assunto em questão, faz-se necessário salientar ainda que a análise de uma representação social sobre infância e criança, permeada por saberes, crenças e valores relacionados com aspectos cognitivos e sociais nos espaços dos Centros de Educação da Primeira Infância, não se dá a conhecer de modo muito simples. Em função disso, a abordagem estrutural das representações sociais abriga distintos métodos de pesquisa científica, bem como diferentes instrumentos de coleta de dados. A teoria das representações sociais possibilita várias contribuições na percepção do processo educativo, porque permite compreender a dinâmica de como e por que as percepções se constroem e se mantêm. Nesse sentido para a Educação não basta apenas constatar questões individuais, mas entender como os pensamentos individuais e coletivos se refletem na prática escolar. Essas várias reflexões são interpretadas pelos professores que criam e recriam novas concepções para compreender a nova situação da sala de aula e conseguir estabelecer uma prática que alcance os objetivos planejados nos espaços educativos.

Por fim, levando em consideração que as representações sociais e as práticas estão intrinsecamente relacionadas, determinando não só comportamentos distintos, 
como também atitudes específicas diante de uma determinada situação (ABRIC, 2003), a maneira como os indivíduos, nesse caso os professores dos Centros de Educação da Primeira Infância, compreendem a infância e a criança pode influenciar na maneira como lidam com esses fenômenos, tanto em relação às atitudes quanto às práticas.

\section{3- Representações sociais no contexto escolar}

A teoria das representações sociais orienta a atenção para o papel de conjuntos organizados de significações sociais dentro do processo educativo.

Alves-Mazzotti (2008, p. 60-61) afirma que o estudo das representações sociais parece ser um caminho promissor, na medida em que investiga justamente "como se formam e como funcionam os sistemas de referência utilizados para classificar pessoas e grupos e para interpretar os acontecimentos da realidade cotidiana". Diante disto, "constitui elementos essenciais à análise dos mecanismos que interferem na eficácia do processo educativo".

A articulação entre a Teoria das Representações Sociais e os estudos educacionais remonta há mais de 30 anos, notadamente, com a publicação, na França, da obra Maître-élève: rôles institutionnels et représentations, de Gilly (2001). Esse autor assinalava, já na década de 80 , que o conceito de representação social é potencialmente pertinente para a compreensão da área educacional na medida em que permite focalizar o conjunto de significações sociais presentes no processo educativo, o que não significa uma redução do campo educacional ao das representações sociais ou vice-versa. Conforme observa Jodelet (2001, p. 13), o campo educativo

não se limita a um espaço de coleta de dados ou um espaço puro de aplicação de um modelo teórico. Ele deve ser pensado como uma totalidade no seio da qual os recursos oferecidos pelo modelo das representações sociais devem ser utilizados de maneira adaptada aos problemas característicos dos diferentes níveis de sua estruturação. O segundo, [no caso, as representações sociais] referente a uma disciplina que tem objetos teóricos, conceitos e procedimentos próprios, e que se orienta por um olhar específico [...], não pode ser absorvida numa simples transferência para campos vizinhos.

Ainda de acordo com Jodelet, essa é uma tarefa apenas iniciada, muito embora o aumento seja considerável, sobretudo no contexto brasileiro, de trabalhos preocupados em promover esse diálogo, conforme indicam os estudos de Madeira (2001), Sousa 
(2002) e Shimizu (2005). Tais estudos deixam claras as possibilidades das representações sociais de evidenciar processos educativos ainda não desvelados por outros referenciais teóricos, na medida em que elas permitem tanto a análise de contextos mais singulares, como é o caso, por exemplo, do cotidiano escolar, como daqueles mais amplos, relacionados às políticas educacionais.

Assim, a Teoria das Representações Sociais nos apresenta uma base importante de análise dos intrigados processos de construção do conhecimento, produzidos no cotidiano educativo, sem desconsiderar aspectos oriundos da história da cultura de uma sociedade, na medida em que as representações sociais vinculam os conhecimentos sobre certos objetos a um sistema de valores que orientam a ação dos indivíduos no meio social, fornecendo-lhes um código para denominar e classificar sua história individual ou coletiva (MOSCOVICI, 2011).

Nessa perspectiva, a Teoria das Representações Sociais vem legitimar e assegurar as funções da escola, conservando e justificando as práticas sociais.

Gilly (2001, p.233) destaca a importância de identificar as representações sociais no campo educativo, pois se trata de um local "privilegiado para se observar como as representações se constroem, evoluem e se transformam no interior dos grupos sociais e para elucidar o papel dessas construções nas relações desses grupos com o objeto de sua representação".

Desta forma, visando o ambiente educativo dos Centros de Educação da Primeira Infância como um sistema social interativo e dinâmico, e tendo como ponto de partida de que em cada CEPI podem existir diferentes representações sobre um mesmo objeto, enfatizamos a relevância de pesquisar acerca das representações sociais dos professores desses espaços sobre infância e criança no contexto escolar.

Assim, é este saber do senso comum, proveniente das interações entre os atores educacionais que permite a orientação de suas condutas e a caracterização do grupo em função de suas representações. Portanto, as representações oriundas das práticas sociais no contexto escolar, permitem uma compreensão mais ampla das decisões no campo educacional.

Conforme Freire (2005, p. 106), os homens “[...] em suas permanentes relações com a realidade, produzem, não somente os bens materiais, as coisas sensíveis, os objetos, mas também as instituições sociais, sua ideias, suas concepções”.

Cabe declarar, que a escola é uma instituição que exerce grande influência no desenvolvimento do indivíduo e na (re) construção das suas representações sociais. Esse 
espaço educativo tem um ponto fundante, preparar indivíduos para atuarem na sociedade, uma vez que nascem em um mundo já estruturado pelas representações sociais e que através destas, eles se desenvolverão e farão parte de um conjunto sistemático de relações e práticas sociais (DUVEEN, 2013).

Diante do exposto, torna-se relevante o estudo das representações sociais sobre infância e criança na perspectiva dos professores dos Centros de Educação da Primeira Infância, enquanto responsáveis pelo processo educativo, pois tais representações sociais vão auxiliar no desvelar de suas práticas.

\section{4- As representações sociais e o diálogo com a sociologia}

A teoria das representações sociais é reveladora de mudanças contínuas que rompem com processos cotidianos e com os aspectos do funcionamento individual que não se mostram suficientes para explicar o fenômeno social, as relações informais, cotidianas da vida humana em um nível propriamente social ou coletivo (SÁ, p. 20, 1993). Essa teoria começa a surgir em um momento da história marcada pela individualização dos estilos de vida, em que a maioria dos teóricos, principalmente da sociologia, fazia clara distinção entre os fenômenos coletivos (cultura ou sociedade) e individuais baseados na crença de que as leis que explicavam os fenômenos coletivos eram diferentes das leis que explicavam os fenômenos individuais (FARR, 2013). Longe de saudar os tempos de outrora, Moscovici (2011) trilhou os caminhos da história contemporânea sob as bases epistemológicas das Ciências Sociais, ancorado no sociólogo Durkheim que foi comparado e diferenciado em suas abordagens.

Historicamente é possível marcar como ponto de partida da teoria das representações sociais a concepção social de Durkheim, que foi um dos primeiros teóricos a utilizarem o conceito de representação (MOSCOVICI, 2011). Durkheim, especificamente, defendia o reconhecimento da oposição entre o individual, que seria domínio da psicologia e o coletivo, domínio da sociologia (FARR, 2013). Para Durkheim, a vida social era substancialmente constituída de representações coletivas que eram radicalmente distintas e exteriores às representações individuais. Ou seja, utilizava a ideia de "representação coletiva" como um dado universal que se impõe ao indivíduo, abrangendo a ciência, a ideologia, a religião, o mito, as categorias de espaço e tempo, ou seja, uma vasta classe de formas intelectuais (MOSCOVICI, 2011). Assim, segundo Farr (2013), se por um lado a essência da representação individual era 
consciência de cada indivíduo sendo, portanto, subjetiva, flutuante e perigosa à ordem social, por outro lado a essência da representação coletiva era a própria sociedade, impessoal e permanente, o que garantia a relação entre os indivíduos e a harmonia da sociedade. Fica claro que Durkheim defendia a separação entre fenômenos sociológicos e fenômenos psicológicos (FARR, 2013).

As divergências da perspectiva sociológica de Durkheim em relação à teoria de Moscovici são que, para este último, a representação social é construída socialmente e não imposta ao indivíduo, ou seja, não é possível separar o indivíduo das influências do seu contexto (grupo social) quando se estuda concepções de um dado objeto; a representação é uma forma particular de adquirir conhecimentos e comunicar o que já tem sido adquirido, deste modo, há uma necessidade de unir as disciplinas sociais e psicológicas para representar a sociedade (FARR, 2013). Por outro lado, corroborando Durkheim, Moscovici coloca a importância de confirmar racionalidade à crença coletiva e sua significação, portanto, às ideologias, aos saberes populares e ao senso comum. E, enfatiza que essa racionalidade das crenças coletivas só pode ser dada através da descrição e explicação dos fenômenos sociais que são o objeto de estudo das representações sociais (MOSCOVICI, 2011).

Os fenômenos sociais e os saberes construídos coletivamente estão presentes nos estudos de Berger e Luckmann (2013), quando trazem a reflexão de que a realidade da vida cotidiana é expressa e representada na análise de como o homem constrói o seu próprio conhecimento da realidade, tratando das relações entre o pensamento humano e o contexto social dentro do qual ele vive. Realidade esta que existe independente de nós, entendida no âmbito sociológico como sendo o conjunto de fatos que acontecem no mundo independente da vontade do indivíduo. Mas que ao ser vista e percebida em perspectivas diferentes pelos ditos Homens forma o conhecimento comum.

Assim, também neste contexto sociológico, o conhecimento pode ser definido como a interpretação que o indivíduo faz da sua realidade. Realidade esta que ainda apresenta-se de forma sui gêneres entre a facticidade objetiva e o significado subjetivo.

Reproduzindo em poucas palavras a essência do entendimento de Berger e Luckmann (2013), podemos sintetizar que a realidade da qual temos consciência, o conhecimento que temos dela, é um produto da sociedade. Sociedade essa construída pelo próprio homem. Assim ao mesmo tempo em que o Homem constrói e molda a sociedade é por ela influenciado, é por ela moldado.

Ouçamos os próprios autores: 
Sendo nosso propósito a análise Sociológica da realidade da vida cotidiana, ou, mais precisamente, do conhecimento que dirige a conduta na vida diária, e estando nós apenas tangencialmente interessados em saber como esta realidade pode aparecer aos intelectuais em várias perspectivas teóricas, devemos começar pelo esclarecimento dessa realidade, tal como é acessível ao senso comum dos membros ordinários da sociedade. Saber como essa realidade do senso comum pode ser influenciada pelas construções teóricas dos intelectuais e outros comerciantes de ideias [...]. Nosso empreendimento engrena-se com a compreensão de uma realidade que constitui a matéria da ciência empírica da sociologia, a saber, o mundo da vida cotidiana. (BERGER e LUCKMANN, 2013, p. 35).

Os autores exploram a questão apresentada passando por uma abordagem dos aspectos sociológicos da realidade e conhecimento, pela análise dos fundamentos do conhecimento na vida cotidiana, pela análise da sociedade como realidade objetiva e pela análise da sociedade como realidade subjetiva.

Nesse sentido, a possibilidade desse encontro sociológico com os estudos de Berger e Luckmann se torna pertinente tendo em vista que a teoria das Representações Sociais tem como objeto o conhecimento cotidiano, o senso comum de uma realidade coletiva e consensual, ou seja, aquela que dá forma à consciência coletiva, explicando coisas e eventos de tal forma que sejam acessíveis a cada um e relevantes aos interesses imediatos (MOSCOVICI, 2011). Essa possibilidade pode nos permitir a entrar nos processos de (re)construção social. Moscovici (2011), pautado na compreensão do cotidiano como movimento, aponta que é possível retomar e criar novos conceitos a partir da teoria das representações sociais. Assim na dinâmica da produção do conhecimento - como nos propõe Berger e Luckmann - o conceito só é explicativo de algo quando já resulta de um processo histórico social.

Por fim, podemos entender as representações sociais como elementos produtores de realidade social, reverberando na forma como o grupo compreende o objeto e o que acontece à sua volta, bem como sobre as respostas encontradas justificando o acontecido. Wagner (2013) colabora com esse debate definindo as representações sociais como uma forma de enfrentamento simbólico, no propósito de domesticar fatos brutos da realidade social com o objetivo de dominar o desconhecido, o não familiar. Uma vez constituída uma representação, os sujeitos procuram criar uma realidade que valide as hipóteses e explicações decorrentes dessa representação. 
Em face do aporte teórico adotado, e o interesse que regulou a elaboração deste estudo, com um olhar mais atento e focado na construção dos fenômenos sociais, foi possível elucidar o cotidiano pedagógico pensado para a criança pequena nos espaços educativos, associadas à representação social de infância e criança predominante nos espaços educativos dos CEPIs, além do reconhecimento de que a história da infância não é apenas uma história de crianças, mas é principalmente de representações sociais específicas que foram construídas, mantidas ou modificadas pelos sujeitos, ao longo do tempo.

No capítulo que se segue serão apresentados os passos utilizados para a realização dessa pesquisa que puderam constituir o nosso percurso metodológico. 


\section{CAPÍTULO III}

\section{PROPOSTA METODOLÓGICA}

Para a execução do estudo - Infância e criança: Um estudo em Representações Sociais com professores de Centros de Educação da Primeira Infância / DF - optamos por uma pesquisa exploratória e descritiva, primeiro porque tem por finalidade esclarecer, modificar conceitos e ideias, tendo em vista a formulação de problemas mais precisos para estudos posteriores em relação à uma proximidade maior com as crianças. Segundo, porque permite a descrição das características de determinada população ou fenômeno e por suas características mais significativas em relação a utilização de técnicas padronizadas de coleta de dados. Essas modalidades de pesquisa possibilitam uma visão geral e aproximativa acerca de um determinado fato. (GIL, 2008, p.27).

Como embasamento teórico-metodológico para o desenvolvimento desta pesquisa, optamos pela Teoria das Representações Sociais, julgando que ela nos possibilitou compreender as lógicas que orientam as práticas partilhadas pelo grupo social educativo dos Centros de Educação da Primeira Infância e que produziu no final, uma visão comum sobre infância e criança, uma vez que por meio dessas representações é possível extrair as percepções construídas sobre realidade dos espaços educativos.

Para realizar a coleta de dados e suas análises, preferimos organizar o trabalho em três momentos:

O primeiro momento contou com a aplicação de um questionário que, para além de caracterizar os sujeitos da pesquisa, buscou perceber quem são esses sujeitos, suas relações com a profissão, seu cotidiano pedagógico, as relações com as crianças e, principalmente, as relações sociais que esses sujeitos têm nos espaços sociais que transcendem os muros dos CEPIs, relações estas elucidadas nas vivências relatadas pelas professoras participantes da pesquisa.

Consideramos esse primeiro momento muito relevante para a pesquisa, pois foi possível desvelar as representações sociais sobre infância e criança das professoras nos CEPIs, bem como suas trajetórias na educação infantil.

O segundo momento possui um caráter qualitativo/quantitativo, já que visou trabalhar/alcançar os seguintes objetivos específicos: Analisar as representações sociais dos professores dos CEPIs sobre infância e sobre criança e identificar os elementos do núcleo central e elementos periféricos do campo das representações sociais dos professores dos CEPIs diante da utilização do "método de associação ou evocação livre 
de palavras", conhecido como TALP, sugerido por Jean-Claude Abric (2003) e a sua posterior análise.

O terceiro momento, por sua vez, terá uma abordagem eminentemente qualitativa, por tratar-se do grupo focal que, segundo Gondim (2003), é uma "técnica analítica que utiliza bases teóricas provenientes da lingüística, psicanálise e sociologia para analisar os conteúdos latentes das opiniões sociais".

Assim, o objetivo principal não é contar opiniões ou pessoas, mas sim explorar as várias opiniões, as diferentes representações sobre o assunto em questão.

Conforme Gatti (2005), em um grupo focal:

1- É possível observar o processo do grupo, a dinâmica da atitude e da mudança de opinião e a liderança de opinião.

2- O ambiente mais natural e holístico, porque os participantes levam em consideração os pontos de vista dos outros na formulação das respostas.

3- O debate aberto e acessível a todos, com assuntos de interesse comum.

4- Proporciona a troca de pontos de vista, ideias e experiências.

5- As diferenças de status entre os participantes não são levadas em consideração.

6- Tradicionalmente compreende de 6 a 8 pessoas desconhecidas anteriormente, mas às vezes a familiaridade entre os participantes pode ser uma vantagem.

7- O moderador tem um tópico guia que sintetiza as questões e assuntos da discussão.

8- O moderador encoraja todos os participantes a falar e responder aos comentários e observações dos outros membros do grupo.

O foco se encontra na análise dos conteúdos manifestos nos grupos, permitindo inferir o sentido oculto, as representações ideológicas, os valores e os afetos vinculados ao tema. Essa abordagem possui um caráter interpretativo, reflexivo e construtivo do objeto de estudo, proporcionando desta forma uma aproximação entre o pesquisador e o objeto de conhecimento. Desta maneira foi possível captar a realidade dinâmica do grupo, o qual nos permitiu a compreensão do processo e percepção de sua relevância social, permitindo uma produção permanente de ideias e conhecimentos como ferramentas imprescindíveis para a sua análise e significação (SILVA, 1998), aspectos 
esses importantes para identificar as representações sociais sobre infância e sobre criança e verificar como se manifestam, na atuação pedagógica, os elementos do núcleo central.

\section{1 - Cenários da pesquisa}

Este estudo elegeu como cenários as seguintes Regiões Administrativas do Distrito Federal: Recanto das Emas e Santa Maria. Essa escolha se deu pela proximidade do pesquisador com as Coordenações Regionais de Ensino dessas cidades e por essas regiões já estarem com seus Centros de Educação da Primeira Infância em pleno funcionamento. Nesse sentido, é imprescindível conhecermos os lugares de onde emergiram as representações sociais aqui analisadas.

A Região administrativa do Recanto das Emas foi criada em 28 de julho de 1993, por meio da lei 510/93, com o objetivo de atender ao Programa de Assentamento do Governo do Distrito Federal. Os antigos moradores desta região relatam que quando foram divididos os loteamentos, esta era uma reunião de chácaras, onde se destacava uma espécie de arbusto chamado canela-de-ema. Existia também no local um sítio chamado Recanto, onde vivia grande quantidade de emas, espécie própria do cerrado. Desta forma originou-se o nome Recanto das Emas. A área prevista para dar origem à nova cidade localizava-se entre a Região Administrativa do Gama e Samambaia e era ocupada por chácaras que pertenciam à Fundação Zoobotânica que foram desapropriadas para distribuição dos primeiros lotes.

À época foram distribuídos 15.619 lotes para inquilinos de varias regiões administrativas, numa previsão de 86 mil habitantes. Hoje o Recanto das Emas deixou de ser um simples assentamento e vem se transformando numa das cidades que mais crescem no Distrito Federal. Sua população já ultrapassa os 160 mil habitantes. Com uma área territorial de 101,48 Km2, o Recanto das Emas fica a 25,8 km do Plano Piloto e limita-se ao norte com Samambaia, ao sul com o Gama, a leste com Riacho Fundo II e a Oeste com município de Santo Antonio do Descoberto - Goiás. Conta com belíssimas reservas naturais. Em 1996, por meio da lei 1.188 foi criado o Parque Ecológico e Vivencial do Recanto das Emas. Essas características conferem grande valor paisagístico ao local, proporcionando à comunidade, e principalmente às crianças, uma área destinada à recreação e lazer em harmonia com a preservação do ecossistema da região. A principal referência da cidade é o monumento das Emas, localizado na entrada do Recanto. A obra foi transformada em cartão postal por ser considerada também um 
patrimônio da cidade. A cidade hoje é formada por 59 quadras residenciais, contando com $100 \%$ de rede de esgoto, $100 \%$ de água potável, $95 \%$ de iluminação e cerca de $99 \%$ de asfalto e drenagem pluvial. A região conta com 24 escolas vinculadas à Secretaria de Estado de Educação do DF. Para além desse montante estão incluídas 04 Centros de Educação da Primeira Infância.

Santa Maria é a segunda região administrativa do Distrito Federal eleita para cenário da pesquisa. Compreende as áreas da Marinha, Saia Velha e o Pólo JK e se localiza a $26 \mathrm{~km}$ de Brasília. A cidade é rodeada por dois ribeirões, Alagado e Santa Maria, este originando o nome da cidade. As primeiras quadras foram ocupadas a partir de fevereiro de 1991. Ocupando uma área de $211 \mathrm{~km}^{2}$, possui uma população de quase 120 mil habitantes. A cidade é fruto de um grande programa de distribuição de lotes realizado pelo governo do Distrito Federal. Assim como outras regiões administrativas do DF, Santa Maria nos primeiros anos era dotada de pouca infra-estrutura urbana, que aos poucos foi sendo consolidada. Hoje, a cidade tem quase $100 \%$ de asfalto. Conta com 26 escolas da Secretaria de Estado de Educação. Possui quatro (4) Centros Educação da Primeira Infância.

Todas as informações sobre as Regiões Administrativas eleitas para a pesquisa foram extraídas do site do Governo do Distrito Federal. Tais informações nos ajudam a perceber a realidade local, bem como o contexto social onde estão inseridos os Centros de Educação da Primeira Infância.

\section{2 - Conhecendo os cenários dos Centros de Educação da Primeira Infância: Um breve Histórico}

Em 2007, o governo federal criou o Programa Nacional de Reestruturação e Aquisição de Equipamentos para a Rede Escolar Pública de Educação Infantil (Proinfância), por considerar que a construção de creches e pré-escolas, bem como a aquisição de equipamentos para a rede física escolar dessa etapa educacional, são indispensáveis à melhoria da qualidade da educação. O programa foi instituído pela Resolução $\mathrm{n}^{\circ}$ 6, de 24 de abril de 2007 e é parte das ações do Plano de Desenvolvimento da Educação (PDE) do Ministério da Educação. Seu principal objetivo é prestar assistência financeira ao Distrito Federal e aos municípios visando garantir o acesso de crianças a creches e escolas de educação infantil da rede pública.

As unidades construídas no âmbito do Proinfância são dotadas de ambientes 
essenciais para a aprendizagem das crianças, como: salas de aula, sala de informática, bibliotecas, sanitários, fraldários, recreio coberto, parque, refeitório, entre outros ambientes, que permitem a realização de atividades pedagógicas, recreativas, esportivas e de alimentação, além das administrativas e de serviço.

Entre 2007 e 2011, o Proinfância investiu na construção de 2.543 escolas, por meio de convênios com os entes federados. A partir de 2011, com a inclusão do Programa no Plano de Aceleração do Crescimento (PAC2), outras 3.135 creches e préescolas foram apoiadas com recursos federais, totalizando 5.678 novas unidades de educação infantil em todo o país. Em 2013 e 2014, o Proinfância teve o desafio de apoiar a construção de mais 3.000 creches e pré-escolas.

O Proinfância repassa também recursos para equipar as escolas em fase final de construção, com itens padronizados e adequados ao funcionamento das creches e préescolas. Mais de 2.500 municípios receberam apoio do FNDE para compra de móveis e equipamentos, como mesas, cadeiras, berços, geladeiras, fogões e bebedouros.

A partir de 2013, as creches puderam ser construídas com metodologias inovadoras, mediante a adesão das entidades beneficiadas pelo Programa às atas de registro de preços do FNDE. Tal procedimento permitiu a redução do prazo de execução e do custo das obras, garantindo, segundo o FNDE, elevado padrão de qualidade.

O Projeto Padrão Tipo B desenvolvido para o Programa Proinfância construídos em Brasília - tem capacidade de atendimento de até 224 crianças, em dois turnos (matutino e vespertino), e 112 crianças em período integral. As escolas de educação infantil são destinadas a crianças na faixa etária de 0 a 5 anos e 11 meses, distribuídos, no Distrito Federal, da seguinte forma:

Creche - para crianças de 0 até 4 anos de idade, onde:

1- Berçário I: 1 turma com 8 crianças

2- Berçário II: 1 turma com 8 crianças

3- Maternal I: 2 turmas com 15 crianças em cada

4- Maternal II: 2 turmas com 15 crianças em cada

5- $1^{\circ}$ Período: 1 turma com 30 crianças

6- $2^{\circ}$ Período: 1 turma com 30 crianças

A capacidade de atendimento por CEPI no Distrito Federal de acordo com o Proinfância do Tipo B é de 136 crianças.

Essa capacidade consta nas Orientações Pedagógicas da Secretaria de Estado de Educação do Distrito Federal (2014) que norteia o trabalho pedagógico em todos os 
Centros de Educação Infantil do DF.

Segundo a Diretoria de Educação Infantil da Secretaria de Estado de Educação do Distrito Federal, o partido arquitetônico adotado foi baseado nas necessidades de desenvolvimento da criança, tanto no aspecto físico, psicológico, como no intelectual e social. Foram levadas em consideração as diversidades existentes nas cidades, fundamentalmente em aspectos ambientais, geográficos e climáticos, em relação às densidades demográficas, os recursos socioeconômicos e os contextos culturais, de modo a propiciar ambientes com conceitos inclusivos, aliando as características dos ambientes internos e externos (volumetria, formas, materiais, cores, texturas) com as práticas pedagógicas, culturais e sociais.

O Distrito Federal pactuou a construção de cento e doze (112) creches, até o ano de 2015, com o Governo Federal, sendo 1 (uma) por intermédio do Programa Proinfância e 111 através do PAC2, para atendimento a crianças de 04 meses a 05 anos. Já foram construídos e estão em pleno funcionamento 41 CEPIs.

Importante ressaltar que as unidades escolares conveniadas com a Secretaria de Educação, que ofertam Educação Infantil, vieram a integrar o sistema público de ensino por força do artigo 89 da LDB 9394/96 que determina que "as creches e pré-escolas existentes ou que venham a ser criadas deverão, no prazo de três anos a contar da publicação desta lei, integrar-se no respectivo sistema de ensino" (ou seja, até dezembro de 1999). Em 2009 a Secretaria de Educação, por meio de convênios tripartites, passou a manter e orientar instituições privadas sem fins lucrativos destinadas a oferta de Educação Infantil, que estavam no campo da Assistência Social.

A escolha dos CEPIs, como cenários para a pesquisa, se deu de forma a contemplar esse novo espaço educativo que começa a acolher a infância e as crianças em toda sua especificidade; se deu, também, pela intenção de analisar as representações sociais dos professores sobre infância e sobre criança em um espaço totalmente pensado para a criança. Por ser novo, esse espaço educativo ainda não recebeu, no seu chão, as contribuições, in loco, de pesquisadores e da Academia. Tendo este estudo o privilégio de ser, um dos primeiros, quiçá o primeiro a adentrar esse espaço podendo contribuir para a construção de uma política pública que faça emergir as infâncias e que percebam as crianças como atores fundamentais na construção social.

Ainda segundo a SEEDF, a opção pelo uso da nomenclatura "Centro de Educação da Primeira Infância (CEPI)", deu-se pelo fato de a educação da primeira infância compreender a faixa etária de 0 a 5 anos, que no caso desses equipamentos que 
estão sendo inaugurados no Distrito Federal, frutos da parceria com MEC/FNDE, destinam-se exatamente a essa faixa etária. E usar o termo "creche" para referir-se a essas unidades de ensino seria equivocado, visto que a legislação (LDB) preconiza que creche é o atendimento a criança de 0 a 3 anos.

O quadro abaixo apresenta os 06 (seis) Centros de Educação da Primeira Infância do Distrito Federal - CEPIs escolhidos para a pesquisa.

Quadro 2 - demonstrativo do contexto e participantes:

\begin{tabular}{|c|c|c|}
\hline $\begin{array}{c}\text { COORDENAÇÃO } \\
\text { REGIONAL DE ENSINO }\end{array}$ & CEPI & 10 \\
\hline Santa Maria & Curió & 09 \\
\hline Santa Maria & Corujinha do Cerrado & 10 \\
\hline Santa Maria & Angelins & 10 \\
\hline Recanto das Emas & Sabiá do Campo & 10 \\
\hline Recanto das Emas & Arara Canindé & 10 \\
\hline Recanto das Emas & Quero-quero & 10 \\
\hline Recanto das Emas & Beija-Flor & 69 \\
\hline TOTAL DE PROFESSORAS & \\
\hline
\end{tabular}

Fonte: SEEDF/2015.

\section{3 - Participantes da pesquisa}

As participantes da pesquisa foram professoras que atuam nas turmas de Educação Infantil, lotadas nos Centros de Educação da Primeira Infância das Coordenações Regionais de Ensino especificadas no Quadro 2.

A escolha por essas professoras vinculadas a essas Regionais de Ensino devese à facilidade de acesso institucional, favorecido pela circunstância do pesquisador atuar na Secretaria de Estado de Educação e ter proximidade profissional com os Coordenadores dessas Regiões Administrativas. 
Outro ponto que nos faz adentrar essas instituições é o fato das professoras dos CEPIs não serem concursadas, fato que aguçou o desejo de compreender quem são essas profissionais que se dispuseram a trabalhar na condição de "contratadas". Todas as professoras estão sob o regime de contratação com carteira assinada, ancoradas na Consolidação das Leis do Trabalho (CLT) nº 5.452/43.

Apesar de demonstrarmos preocupação em relação à contratação das professoras, o que nos traz como ponto para reflexão é justamente quem são esses sujeitos participantes da pesquisa. Em como eles pensam a infância e criança, como concebem essa infância e essas crianças que estão em contato com a construção do conhecimento nos espaços educativos, construindo cultura social, ou seja, como constroem os elementos do núcleo central e sistema periférico do campo das representações sociais e, ainda, como esses elementos do sistema central e sistema periférico do campo das representações sociais se manifestam no cotidiano pedagógico.

\section{4 - Procedimentos / Levantamento de dados}

Para a efetivação da pesquisa foram utilizadas as estratégias / instrumentos a seguir:

No intuito de conhecer mais a fundo os sujeitos participantes da pesquisa, optamos pela aplicação do questionário (apêndice A) composto por sete (07) questões abertas e seis (06) questões fechadas, para compreendermos esses sujeitos, suas relações com a profissão, com as crianças e, principalmente, como essas relações estão ligadas às suas vivências sociais.

Os dados coletados foram tratados, organizados e analisados a partir das diferentes mensagens, informações e enunciados apresentados nas respostas dos participantes, com a finalidade de identificar elementos que possuíssem uma interrelação e que poderiam dar sentido a uma ideia. Esse processo baseou-se na adaptação da técnica da análise de conteúdo proposta por Bardin (2002).

Para o segundo momento utilizamos, ainda, a técnica de evocação livre de palavras - TALP, sugerida por Jean-Claude Abric (1998 in SOBRINHO, 2010). Ela consiste na solicitação de cinco a seis palavras, ou expressões, a serem evocadas imediatamente após a apresentação de um termo indutor, seguidas pela escolha hierárquica e repetição de três dessas evocações segundo o grau de importância para o entrevistado e, finalmente, se conclui pela justificativa daquela que foi selecionada 
como a mais importante. Desta maneira, torna-se possível identificar o universo semântico (o conteúdo) do objeto de estudo e o seu aspecto imagético (Idem).

As palavras e expressões resultantes desse instrumento foram submetidas à análise lexical do software EVOC (Ensemble de Programmes l'Analise des Évocations -Vergès, 2000) com o intuito de identificar o núcleo central e os níveis periféricos que formam a estrutura da representação social dos participantes do estudo. Esse instrumento permitiu verificar a estrutura da representação social a partir da combinação entre a frequência e a ordem das palavras e expressões evocadas, considerando também a importância atribuída a elas.

O enunciado do instrumento constou de uma solicitação do registro de seis palavras diante dos termos indutores “infância é:" e "ser criança é:", seguindo o critério de hierarquizar as palavras por grau de importância, justificando suas escolhas.

Ao final do uso do instrumento de associação livre de palavras, colocamos uma observação convidando os participantes da pesquisa a continuarem participando do terceiro momento do estudo. Aquelas que concordaram, deixaram seu contato, nome, telefone e e-mail. Diante dessas informações, realizamos o contato para dar prosseguimento ao próximo momento.

No terceiro momento, utilizamos o procedimento para levantar os dados 02 Grupos Focais, com 02 encontros cada e participação de 09 professoras dos CEPIs, voluntárias, em cada grupo, nos quais foram feitas gravações de áudio, tendo como tema “infância e criança”. Para análise desses dados utilizamos a Análise de Conteúdo proposto por Bardin (2002), identificando, assim, as representações sociais dos professores sobre infância e sobre criança, bem como, os elementos do núcleo central do campo das representações sociais e verificando como os elementos do núcleo central do campo das representações sociais se manifestam no cotidiano pedagógico das professoras participantes.

\section{5 - Procedimentos}

Inicialmente solicitamos permissão para a realização da pesquisa nas Coordenações Regionais de Ensino de Santa Maria e Recanto das Emas para, em seguida, fazer o levantamento da quantidade de CEPIs e quais desses poderiam constituir a amostra da pesquisa. 
Logo após, foi realizada uma visita em todos os CEPIs das duas regiões administrativas eleitas para a pesquisa. A intenção era fazer uma breve apresentação do tema, do termo de consentimento livre e esclarecido às gestoras dessas instituições e do instrumento que seria aplicado aos professores. Nenhum contato foi feito por telefone, o que facilitou uma empatia significativa para a participação das instituições. Nesses encontros, também foram acordados os dias que iríamos aplicar os instrumentos nos CEPIs. Esses encontros estavam organizados para acontecer no horário de coordenação pedagógica das professoras, no turno contrário ao da regência de classe. Ressaltamos que nenhum gestor opôs-se à aplicação dos instrumentos de evocação livre de palavras e não foram encontrados entraves para a sua efetivação.

Os grupos de professoras que encontramos, em sua maioria, também não demonstraram resistência em participar da pesquisa e em assinar o termo de consentimento livre e esclarecido. Entretanto, tiveram aquelas que argumentaram que não dava tempo de responder os instrumentos de pesquisa, pois o questionário para caracterização/perfil dos participantes e a evocação livre de palavras - TALP foram feitos no mesmo dia e hora marcados. Respeitamos as suas colocações e demos prosseguimento à pesquisa.

Após a aplicação do instrumento de evocação livre de palavras, tabulamos os dados e os preparamos de acordo com o campo semântico das palavras ou expressões, (onde tinha brincar e brincadeira optamos, por exemplo, em assumir todas como brincadeira) para, então, submeter esse material a uma análise pelo software EVOC.

Ao identificarmos o conteúdo das representações sociais e as suas estruturas internas, iniciamos a etapa da pesquisa com a realização dos grupos focais com as professoras que concordaram em participar desse momento. Vale ressaltar que os grupos focais tiveram 9 participantes cada.

Realizamos a análise desse material gravado, transcrito posteriormente, com base na análise de conteúdo proposto por Bardin (2002). Buscamos construir as categorias e classes de análise do material, no intuito de identificar os elementos que se (inter) relacionassem e evidenciassem as representações que as professoras participantes da pesquisa possuem sobre da infância e da criança. 


\section{CAPÍtULO IV}

\section{ANÁLISE DOS DADOS}

\section{1 - Os caminhos para as Análises}

Para a interpretação das informações coletadas por meio dos questionários de caracterização dos sujeitos, questionário de livre evocação de palavras e dos grupos focais, foi realizada cuidadosa interpretação, procurando captar o observável e interpretar os aspectos implícitos. Para isso, após a realização de cada estudo, as informações foram organizadas sem categorias previamente definidas. Sua análise ocorreu paralelamente a sua coleta, buscando garantir a coerência teórica e metodológica.

A opção por variadas fontes de informação foi fundamental para o confronto dos dados e o aprofundamento das questões norteadoras da pesquisa, possibilitando a "triangulação, ou seja, checagem de um dado obtido através de diferentes informantes, em situações variadas e em momentos diferentes" (LUDKE et al., 1986, p.52), imprimindo maior confiabilidade e visibilidade aos resultados da pesquisa.

Os procedimentos metodológicos possibilitaram a construção de uma visão ampla do processo desta pesquisa e das leituras ainda necessárias. Subsidiaram nossas reflexões que serviram de alicerce, na medida em que impulsionaram o investimento nesse caminhar, ciente de que a realidade não será construída a posteriori; ela existe e se constitui cotidianamente antes mesmo de nossa incursão no campo de pesquisa, sendo necessário olhar para essa realidade sempre questionando a si mesmo, ao percurso metodológico escolhido, consciente de que a descoberta não consiste em ver o que todos vêem, mas em pensar o que ninguém pensou.

Nesse caminhar metodológico, como dito anteriormente, optamos pela análise de conteúdo (BARDIN, 2002), por nos permitir uma produção de inferências e melhor compreensão sobre a relação entre comportamento humano e representações sociais (MOSCOVICI, 2011). A análise de conteúdo se estrutura como concepção crítica e dinâmica da linguagem. Ela se constitui em

[...] um conjunto de técnicas de análise da comunicação e para tanto faz uso de procedimentos sistemáticos e objetivos de descrição do conteúdo das mensagens. A análise de conteúdo se propõe a fazer inferências sobre os conhecimentos relacionados às condições de produção e de recepção das mensagens, buscando assim os indicadores quantitativos ou qualitativos (BARDIN, 2002, p.37). 
Para análise de conteúdo do material coletado, desenhamos a trajetória ensinada por Bardin (2002), que se constitui basicamente de quatro passos, a saber:

1- Na primeira etapa da análise, após a coleta dos dados, procedemos à transcrição das falas dos professores, o que constituiu um exercício árduo que exigiu dedicação, tempo e muita atenção, já que respeitamos os detalhes de pausas, silêncios e repetições. Tivemos que ouvir os áudios mais de uma vez para fazer o registro adequado da situação. Mesmo sendo um trabalho que exigiu tempo e dedicação, pois não delegamos a responsabilidade da transcrição para outrem, o que nos rendeu a possibilidade de reviver as interações entre as professoras e configurou-se como um primeiro momento de análise.

2- A segunda etapa de análise destinou-se à pré-análise do material. Nesse momento, procedemos à leitura flutuante a partir da qual foi possível uma exploração mais detalhada do vasto material. Considerando que obtivemos um material extenso, selecionamos a parte dele que estava diretamente relacionada ao nosso objetivo e seguimos com a organização das falas em unidades de sentido.

3- A partir da organização das falas em unidades de sentido, no formato de frases resumidoras de um significado, chegamos ao agrupamento em categorias, uma construção feita pelo pesquisador a partir dos conteúdos emergidos das falas das professoras, em consonância com os objetivos da pesquisa. Essas categorias foram organizadas por afinidade de sentido.

4- Por último, procedemos ao tratamento dos resultados em consonância com a literatura. De acordo com Moraes (1999), a análise do conteúdo, embora tenha sido orientada por muito tempo pelo paradigma positivista, tem atingido novas e mais desafiadoras possibilidades à proporção que se integra à exploração qualitativa. Nessa perspectiva, o investigador pode escolher o tipo de conteúdo que deseja examinar: conteúdo manifesto ou conteúdo latente. O nível manifesto, de acordo com Moraes (1999), está associado a uma leitura representacional, enquanto o conteúdo latente, com o qual trabalhamos neste estudo, trata de uma compreensão mais profunda, revelado pelo não dito, pelas 
entrelinhas, as motivações inconscientes, articulando o texto com o contexto psicossocial e cultural, relacionando-a a uma análise indutiva, gerativa, construtiva e subjetiva.

Para melhor entendimento do percurso metodológico proposto nesta pesquisa, apresento a seguir a Figura 1. 


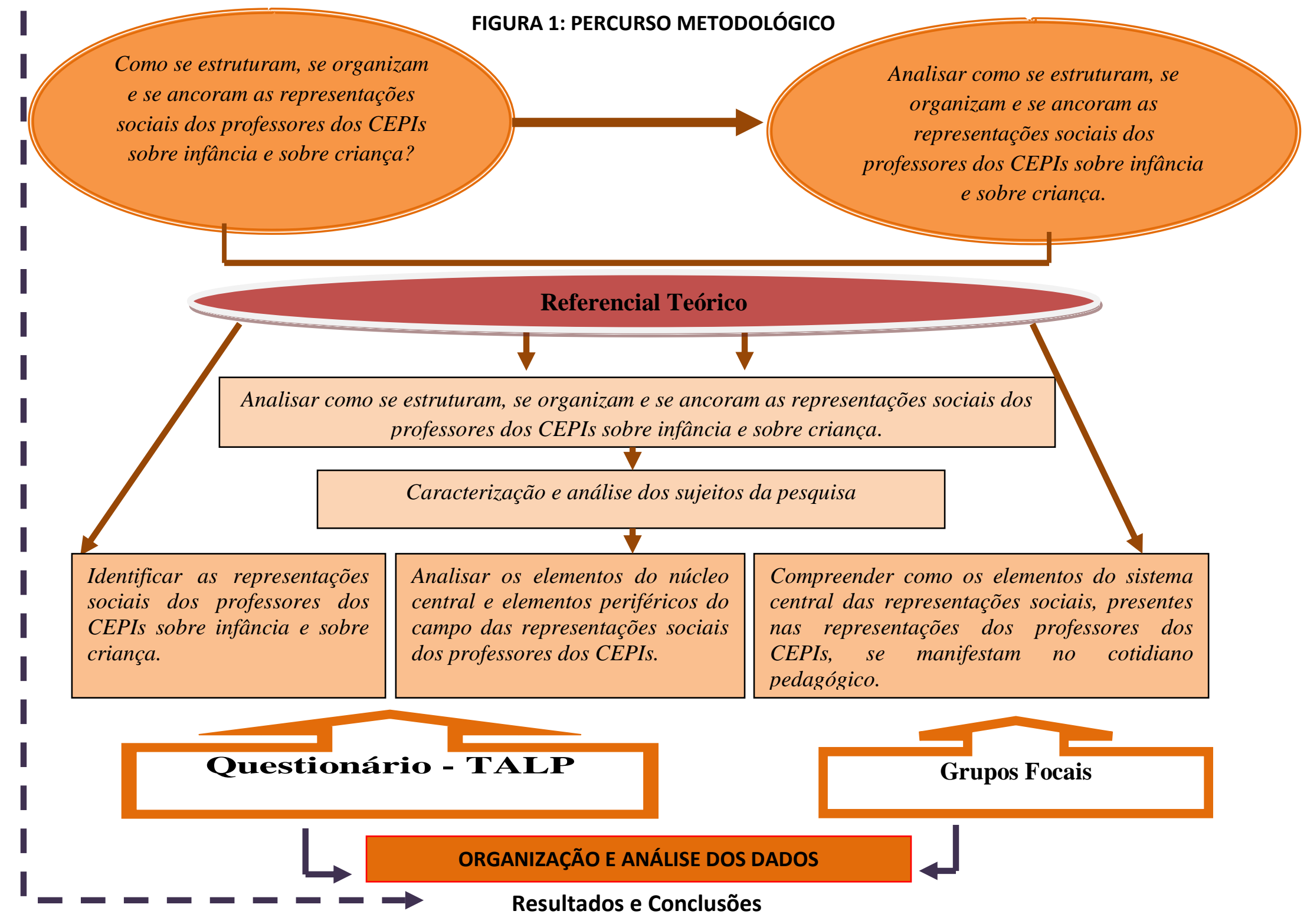




\section{2 - A Caracterização dos sujeitos da pesquisa}

Este primeiro estudo foi classificado quanto a sua abordagem em qualitativa/quantitativa; quanto ao nível da pesquisa em descritiva e quanto ao procedimento utilizado para a coleta de dados em documental (GIL, 2008). A coleta de dados se deu nos CEPIs, sendo que a fonte principal foi o questionário de caracterização das professoras participantes.

O mesmo foi realizado no ano de 2015 , contando com a participação de seis Centros de Educação da Primeira infância das cidades Recanto das Emas e Santa Maria. Em função de não contemplar todas as instituições, a pesquisa buscou abranger os CEPIs de duas das regiões administrativas do Distrito Federal.

No primeiro momento, os dados foram obtidos por meio de um questionário previamente elaborado e entregue em cada local para ser preenchido pelas professoras das instituições, que concordaram de modo voluntário a participar da pesquisa.

Nos campos do questionário, foi elencado o número de profissionais atuantes nos CEPIs, a atuação na educação infantil, o nível de escolaridade, suas relações sociais e outros dados de caracterização. Por fim, a análise de caracterização dos participantes da pesquisa enfatizou elucidar quem são os sujeitos da pesquisa, suas relações sociais e como essas estão permeadas no cotidiano pedagógico.

$\mathrm{O}$ número de profissionais que participaram desse primeiro momento da pesquisa foi de 69 (sessenta e nove) professoras. Nas observações informais constatouse que não há homens trabalhando nas salas de aula dos CEPIs. Quando perguntado às gestoras da predominância das mulheres na Educação Infantil, todos responderam que "é mais fácil para trabalhar com as famílias". Notamos uma questão bastante enraizada em relação ao gênero, principalmente em relação aos pais que demonstram, segundo as gestoras, uma preocupação com as crianças na hora da higiene pessoal, principalmente das meninas. O que nos faz corroborar a representação social de que, historicamente, há uma prevalência de mulheres atuando na educação infantil (VIANNA, 2002; WERLE, 2005) e, pela mulher ter um papel mais efetivo na educação das crianças nessa faixa etária. 


\section{Gráfico 1 - Faixa etária dos participantes da pesquisa}

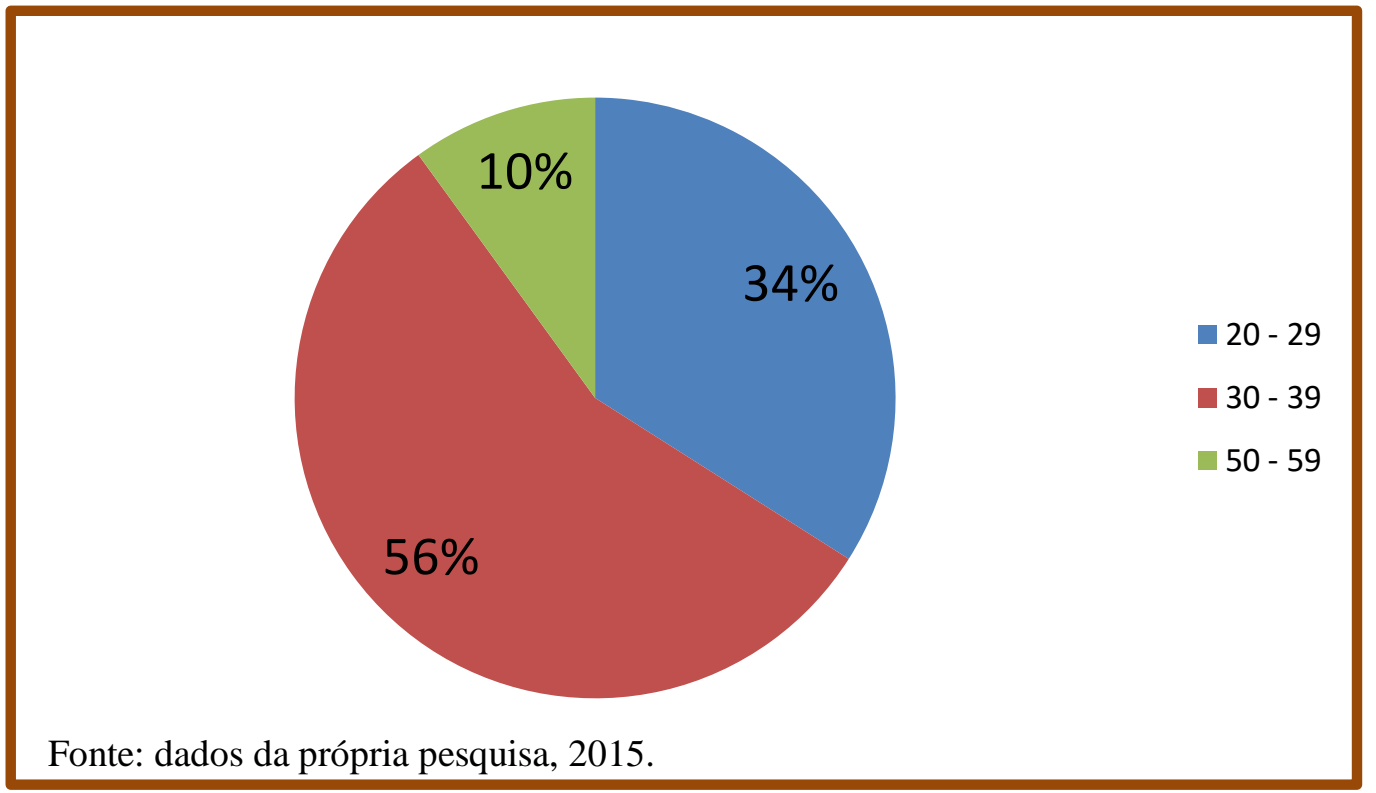

Das 69 professoras entrevistadas 39 estão na faixa etária dos 30 anos de idade (56\%), 23 na faixa etária dos 20 anos de idade (34\%) e 7 na faixa etária dos 50 anos de idade $(10 \%)$. De modo geral, verifica-se que predomina a maioria de jovens professoras contratadas $-80 \%$.

\section{Gráfico 2 - Formação dos participantes da pesquisa}

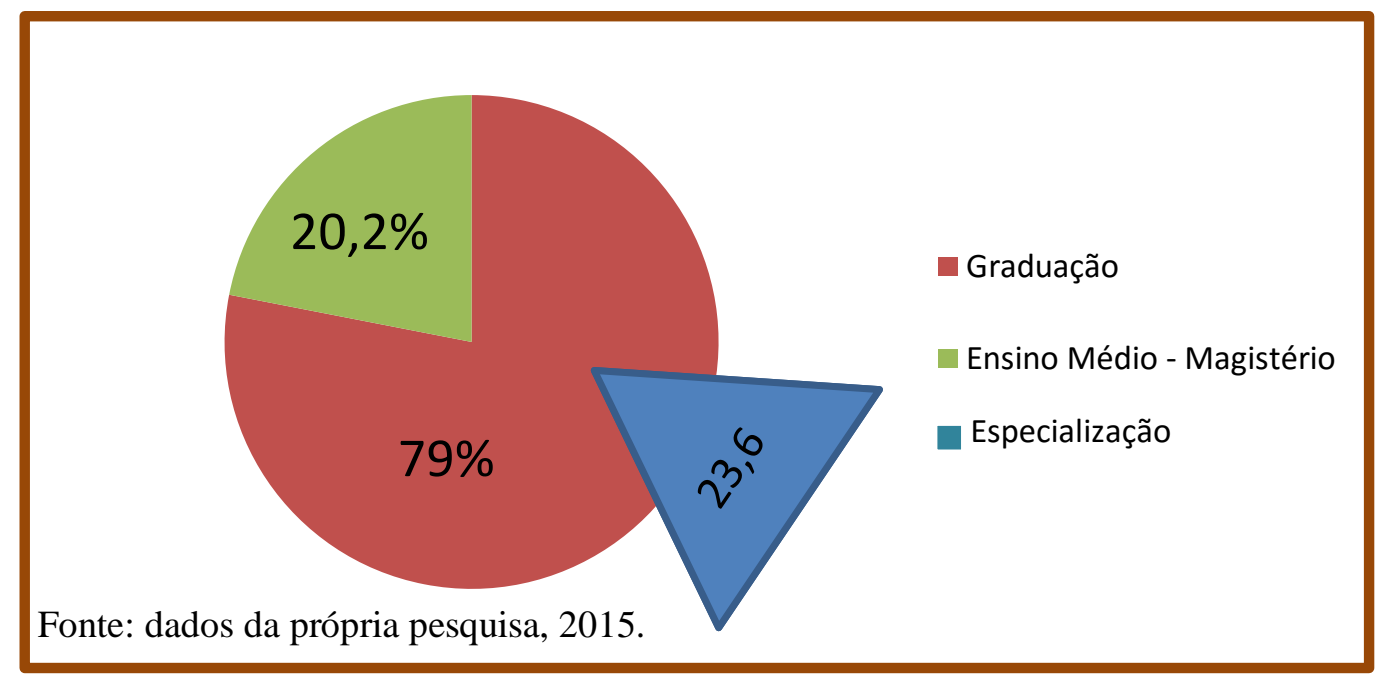

Sobre o nível de escolaridade das professoras, os dados apresentados, indicam um predomínio (100\%) do ensino médio Completo (magistério).

Entretanto temos $79 \%$ das sessenta e nove professoras com formação em nível superior completo e, dessas, $23 \%$ com especializações na área de Educação, embora 
ainda não seja a ideal, isso porque encontramos 20,2 \% das 69 professoras que ainda não concluíram o curso superior, pois ainda estão cursando.

Os resultados apresentados merecem alguns destaques, dentre eles, inicialmente comentaremos sobre o regime de contrato de trabalho dos professores. Como já elucidado anteriormente, há um predomínio do regime de contrato de trabalho/ CLT. Pensamos que, apesar de estarem asseguradas nas leis trabalhistas, é inegável aqui o retrocesso no que diz respeito aos ganhos que a categoria do magistério tem alcançado nos últimos anos, principalmente no Distrito Federal com a reformulação do Plano de Carreira dos Profissionais da Educação aprovado e sancionado no ano de 2014. no que diz respeito, especificamente, sobre o regime de concursos públicos para professores no Distrito Federal, num tempo em que deveria ocorrer o oposto.

Em 2013, o Governo Federal lançou o "Brasil Carinhoso", colocando a educação infantil como uma das modalidades de maior atenção por parte das esferas federal, estadual e municipal. Um dos focos dessa atenção deveria ser a formação do profissional, em muitos casos, atrelada ao vínculo institucional (ROSSETI-FERREIRA, 2000). Não podemos esquecer, porém, que, até 2010, a Educação Infantil no Distrito Federal era de responsabilidade exclusiva da Secretaria de Estado de Educação do Distrito Federal, oferecida nas instituições públicas dessa rede. Contudo, com a necessidade de aumentar a demanda de oferta da Educação Infantil, o Distrito Federal também aderiu ao conveniamento de instituições educacionais privadas, sem fins lucrativos, comunitárias, confessionais e filantrópicas, processo este que, do ponto de vista da garantia dos direitos trabalhistas e da garantia de uma educação pública e de qualidade, merece um alerta de atenção preocupante por parte da categoria de professores do Distrito Federal, quiçá de todo o Brasil.

Um segundo ponto a ser destacado, refere-se ao nível de escolaridade dos professores atuantes nas instituições analisadas. Sobre isso, observamos um predomínio do ensino médio completo (magistério), contando com 20.2\%, como mostrado no gráfico 2, de professoras que ainda não tem curso superior. Sabemos, no entanto, que há inúmeras discussões sobre esse nível não ser suficiente para atender às necessidades da educação infantil.

Não se pode pensar simplesmente em ignorar esse contingente ainda em formação que ainda atua nessa etapa. Nesse sentido, corroboramos com Kishimoto (2007) quando nos elucida que precisamos de uma política de formação profissional para a educação infantil que "garanta um processo democrático que permita a ascensão 
na escolaridade, em todos os níveis, e a valorização dessa formação no patamar de outros cursos" (KISHIMOTO, 2007).

Algumas experiências, principalmente na área de ensino e extensão, mostram que os trabalhos multidisciplinares têm contribuído, sobremaneira, para essa formação em serviço e para repensar sobre esse perfil profissional tão almejado (OLIVEIRA et al., 2010; VASCONCELLOS, 2001).

Refletindo sobre a implicação que a formação dos professores tem em relação ao cuidado e à educação das crianças que frequentam os CEPIs, tem-se os seguintes aspectos: mesmo que o foco da educação infantil não seja propriamente a escolarização, essa etapa inicial da educação básica requer também planejamento específico de atividades e de brincadeiras que irão auxiliar no processo de escolarização, posteriormente.

Sendo assim, questiona-se até que ponto uma pessoa com formação no ensino médio (magistério) possui conhecimento suficiente em relação ao processo de desenvolvimento infantil, bem como acerca dos objetivos da educação infantil capaz de fornecer subsídios para um planejamento pedagógico com vistas ao favorecimento de todo esse processo?

Machado (2000) por sua vez, numa perspectiva sócio-interacionista, propõe que o professor de educação infantil seja capaz de organizar o espaço, o tempo, os materiais, os agrupamentos de crianças e propor atividades que promovam as interações de modo desafiador.

Se conhecimentos técnicos são exigidos, o compromisso pessoal e político com a causa da infância é também primordial, enquanto categoria social que corresponde a um período peculiar da vida do ser humano, em um determinado momento sóciohistórico de um mundo complexo, contraditório e em constante mudança.

Portanto, a questão a ser elucidada é a de que a profissionalização no campo da educação infantil não se dá apenas em função da formação inicial, mas, também, a partir da atuação direta na área, da experiência acumulada, da aprendizagem cotidiana, das interações com os diferentes profissionais e familiares envolvidos. Trata-se de delinear um modelo de profissional que toma sua própria prática pedagógica como objeto permanente de reflexão. O que, em hipótese nenhuma, abona a formação continuada como caminho fundamental para qualificar a prática pedagógica. 
Quando a preocupação é a da formação da pessoa cidadã, defende-se uma concepção de desenvolvimento da pessoa intrinsecamente articulada à concepção de desenvolvimento profissional, que vem norteando novos modos de pensar e agir nos projetos de formação (MACHADO, 2000).

Nesse sentido, a formação de professores que atuam nesse segmento é um dos fatores fundamentais para a garantia da qualidade dessa educação inicial que deve ser compreendida como orientações e práticas pedagógicas, apoiadas fundamentalmente em aspectos de promoção do desenvolvimento infantil, pois serão essas ações que darão suporte tanto para o processo de alfabetização como de construção da cidadania (OLIVEIRA, 2008).

É preciso considerar que passamos por um momento de implementação de políticas públicas de investimento e financiamento da Educação de 0 a 5 anos, no âmbito federal. Investimento este entendido não apenas como contratação de profissionais, mas também como qualidade de atendimento, com planejamentos que traduzem uma preocupação com o nível da educação e, principalmente, que se traduzem em articulação administrativa e pedagógica. Isso perpassa, sem dúvida, por uma melhoria das condições de trabalho, salário e principalmente formação profissional.

O tempo de atuação na educação infantil, como veremos no gráfico 3 , também é um importante dados a ser explorado aqui nesse primeiro estudo, sobretudo porque nos mostra o percurso da formação dessas profissionais, o tempo percorrido por elas até chegar às salas de aula e a disposição heterogênea desse tempo que nos mostra a experiência pedagógica na educação infantil.

\section{Gráfico 3 - Tempo de atuação na Educação Infantil}

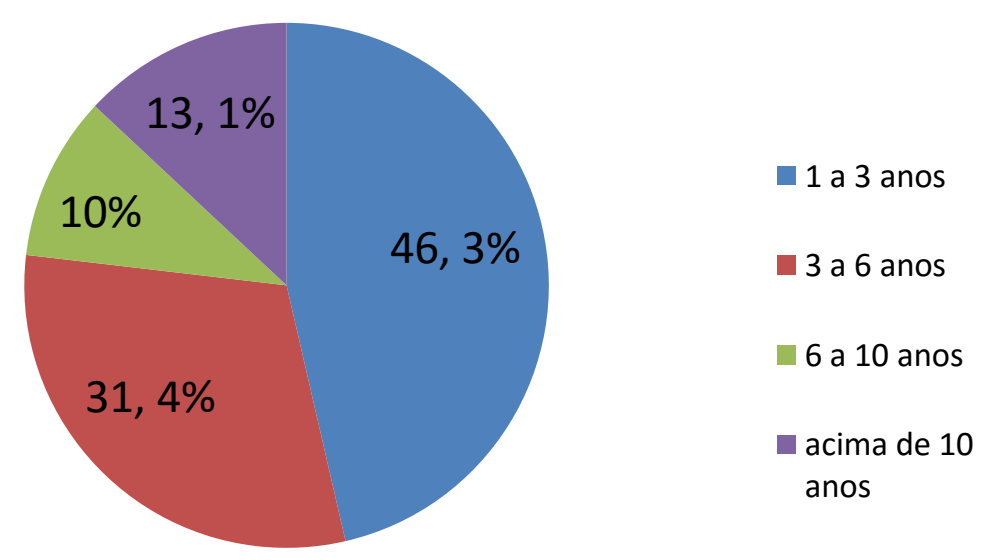

Fonte: dados da própria pesquisa, 2015. 
Quanto a disposição heterogênea de tempo no magistério, entendemos que ela favorece uma análise mais complexa sobre representações provenientes de diferentes contextos históricos. Esses dados convergem para o entendimento de que trata-se de um grupo de professoras com tempo de experiência relativamente curto em docência na Educação Infantil.

\section{Gráfico 4 - Maternidade}

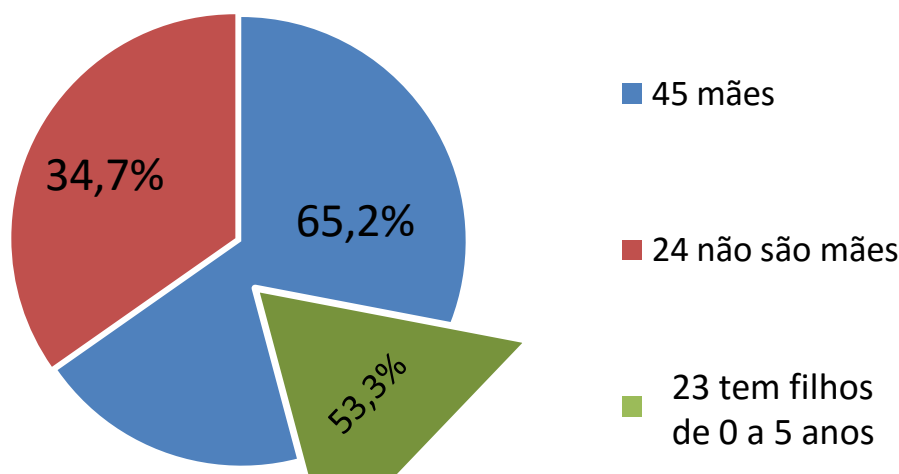

Fonte: dados da própria pesquisa, 2015.

O questionário aplicado nos mostra outro dado de grande relevância para a nossa análise, pois diz respeito a maternidade das professoras contratadas pelos CEPIs. Podemos notar que, das 69 (sessenta e nove) professoras contratadas, 65,2\% professoras são mães e, dessas, 53,3\% das professoras têm filhos menores de seis anos, ou seja, na mesma faixa etária das crianças que elas atendem nas instituições de educação infantil. Ressalta-se aqui que alguns filhos frequentam estas mesmas instituições, o que sugere que as representações sociais investigadas nesta pesquisa estão sendo geradas e transformadas nas experiências destas professoras não apenas como professoras, mas também como mães de crianças que são atendidas na Educação Infantil do Distrito Federal.

\section{Gráfico 5 - Religião das participantes da pesquisa}

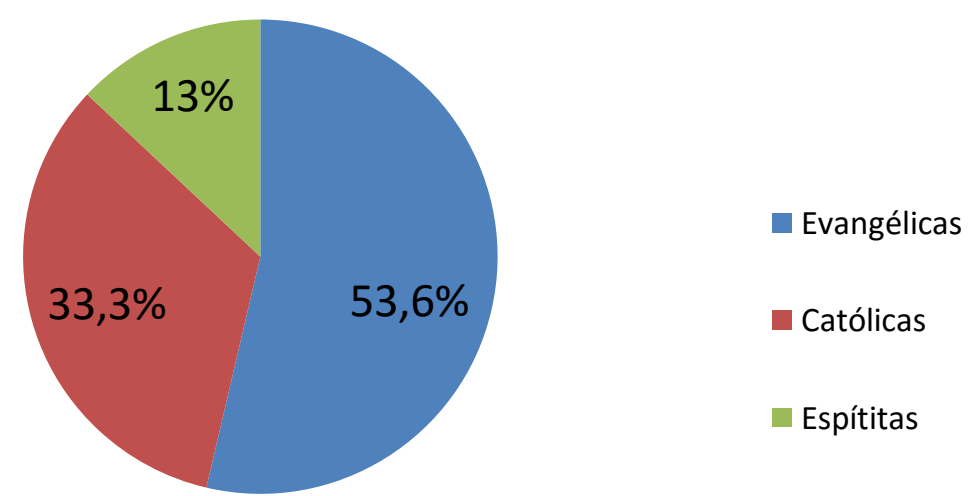

Fonte: dados da própria pesquisa, 2015. 
O grupo entrevistado, em sua maioria é Cristão. São 33,3\% de professoras católicas, 53,6\% de evangélicas e 13\% espíritas. Contudo, quando perguntado sobre participação em grupos sociais, 52 professoras afirmam não participar, nem mesmo dos grupos religiosos. Dessas, 23 professoras disseram que gostam de ir à igreja quando não estão trabalhando.

É imprescindível elucidarmos aqui as questões apontadas, pelas professoras, quando perguntado sobre "o que mais gostam de fazer em sala de aula" e "o que não gostam de fazer em sala de aula". Destacamos, entre o "que mais gostam de fazer" as atividades em folha para pintura, trabalhos manuais, ensinar a escrever e alfabetizar. Conforme nos mostra o quadro 3:

Quadro 3

O que mais gosto de fazer

“Ensinar a escrever, principalmente o pré-nome e ouvir as crianças. ” Professora do II período

“Acho lindo quando vejo que meus alunos já estão escrevendo.” Professora do I período

“Eu gosto de levar atividades nas folhas. Acho que eles gostam. Eles ficam mais quietos”. Professora do II período

"Na verdade eu gosto mesmo é de alfabetizar, mas dizem que não podemos na creche." Professora do I período Fonte: dados da própria pesquisa, 2015.

Percebe-se que algumas professoras, em suas práticas em sala de aula, vêem a necessidade de alfabetizar as crianças da Educação Infantil, mesmo o Currículo em Movimento da Educação Básica / Educação Infantil (2014) orientando que a Educação Infantil, em que não objetivamos ensinar a criança a escrever convencionalmente, ela utiliza sua produção gráfica, o desenho, a fim de comunicar-se. Nesse sentido, a orientação para a Educação Infantil é a de apresentar o mundo letrado às crianças, introduzindo-as em um contexto de letramento próprio da vivência delas, como nos elucida o Currículo em Movimento:

[...] não se espera que as crianças, na Educação Infantil, dominem o sistema alfabético. $\mathrm{O}$ que se pretende é que aprendam a refletir sobre esse sistema e participem criticamente da cultura escrita, de modo a adquirir o gosto pela escrita e encontre recursos para fazê-lo. Não existem razões para a escola atrasar ou cercear a aprendizagem da escrita, porém, também deve existir a intenção de acelerar ou estimular precocemente tal aprendizagem. (Distrito Federal, 2014, p. 118). 
Portanto, percebemos que as práticas pedagógicas dos professores do Ensino Fundamental anos iniciais ainda transitam e se confundem com as práticas previstas e apontadas para a Educação Infantil, ficando clara a necessidade de uma formação continuada que vislumbre estabelecer e esclarecer o cotidiano pedagógico nos CEPIs, com uma intencionalidade didática voltada para o atendimento das crianças de 0 a 5 anos.

Quanto ao item “o que não gosto de fazer?”, percebemos uma dificuldade por parte de algumas professoras em promover uma didática própria e necessária para a educação infantil. Muitos relatos como não gosto de "Disponibilizar brinquedos, fazer a rodinha, preencher diário, fazer reunião com os pais e recreação", nos ajudam a elucubrar sobre a necessidade, dita anteriormente, de uma formação continuada que contemplem as práticas pedagógicas próprias para a Educação Infantil. Vemos aqui, claramente, comparando-se ao item "o que mais gosto de fazer" que as práticas do Ensino Fundamental, internalizadas no cotidiano escolar e referendadas nas representações sociais das professoras, apontam um caminhar desafiador no que diz respeito às rotinas pensadas nos planejamentos pedagógicos dos CEPIs, quiçá de todas as instituições públicas de Educação Infantil do Distrito Federal. Podemos perceber essas representações nos relatos abaixo:

\section{Quadro 4}

\section{O que não gosto de fazer}

"Fico perdida quando as crianças utilizam os brinquedos. Prefiro não dar. Faço outras coisas." Professora do II período

"Não tenho o hábito de fazer rodinhas. Gosto de fazer só pra refletir sobre o comportamento deles." $\quad$ Professora do II período

"Não suporto preencher o diário e fazer os relatórios. Ninguém lê isso. Perda de tempo." Professora do I período

"Fazemos reuniões com os pais sempre, mas vejo que não adianta. Eles não nos ajudam. Prefiro não fazer." Professora do I período

"Fico tensa na recreação das crianças. Tenho dificuldade para controlar eles. Não gosto." Fonte: dados da própria pesquisa, 2015.

Professora do II período

O brincar e o interagir, as rotinas, as experiências compartilhadas com as famílias são práticas alicerçadas e importantíssimas, precisam estar presentes no cotidiano pedagógico das crianças na Educação Infantil. O Currículo em Movimento (2014) referenda essas práticas quando nos afirma que: 
A maneira como as interações acontecem no âmbito da instituição influencia na qualidade do processo de aprendizagens e desenvolvimento. À vista disto, o coletivo, a troca de experiência, a relação com objetos, pessoas e os elementos sociais e culturais contribuem decisivamente para a construção de vínculos com o outro e com o conhecimento. (Distrito Federal, 2014, p. 39)

Percebe-se que o fato de algumas professoras optarem por não promover o lúdico e ingressar em uma caminhada de alfabetização com as crianças na Educação Infantil, acontece porque é "mais fácil" para manter a disciplina da turma. Isso fica evidente quando as professoras dizem ter "dificuldades para controlar a turma" quando são oferecidos brinquedos ou quando atividades de recreação são planejadas.

Isto feito, deparamo-nos com três aspectos que caracterizam esse grupo de professoras que atuam nos CEPIs e que chamam bastante a atenção porque acreditamos que eles possuem fortes influências sociais e contrastam entre si.

Esses aspectos são:

1- A predominância (100\%) feminina nesse segmento da educação. Fica clara a opção de atuação muito bem aceita socialmente (isso referendado na fala das gestoras). O papel da mulher na educação infantil, nos parece ainda atrelado ao exercício da função materna e o cuidado das crianças. Esse aspecto nos leva a refletir sobre que ainda se faz necessário um estudo que nos ajude a elucidar a diversidade de gênero no magistério;

2- A formação das professoras participantes da pesquisa. Nota-se que $79 \%$ das professoras possui nível de escolaridade superior. Isso demonstra, a nosso ver, uma preocupação com a formação inicial e o investimento de políticas públicas voltadas para a formação de professores, alicerçando o pensamento da educação voltada para as crianças, que vai muito além do cuidar.

3- O contraponto entre o "que mais gostam de fazer" e o "que não gostam de fazer" em sala de aula, é um outro aspecto a ser destacado aqui, pois nos faz refletir que, mesmo com o investimento em formação inicial e continuada, as professoras ainda projetam em suas práticas na educação infantil, as práticas comumente desenvolvidas no ensino fundamental. 


\section{3 - Segundo Momento - Análise das Evocações}

O segundo estudo buscou identificar as representações sociais dos professores dos Centros de Educação da Primeira Infância - CEPIs sobre infância e criança e compreender como essas representações sociais se estruturam, conforme proposto por Abric (1998), na Teoria do Núcleo Central. Essa teoria contribui, dentre outros aspectos, para compreender o processo de constituição e transformação de uma representação social.

Para que esse caminho se concretizasse, conforme retrocitado, utilizamos a técnica de evocação livre de palavras - TALP para realizar a coleta de dados dos participantes e posteriormente submetê-los a uma análise pelo software EVOC. Esse programa permite identificar as representações de um grupo e a sua estrutura, porque ele evidencia os elementos pertencentes ao núcleo central e a sua periferia, organizados em quadrantes a partir da frequência e ordem em que as palavras, ou expressões, foram apresentadas no instrumento utilizado, conforme pode ser observado nas figuras 2 e 3 a seguir. Ressaltamos que a primeira apresenta a estrutura da representação social sobre a infância e a segunda, da criança.

Figura 2 - Quadrante Infância

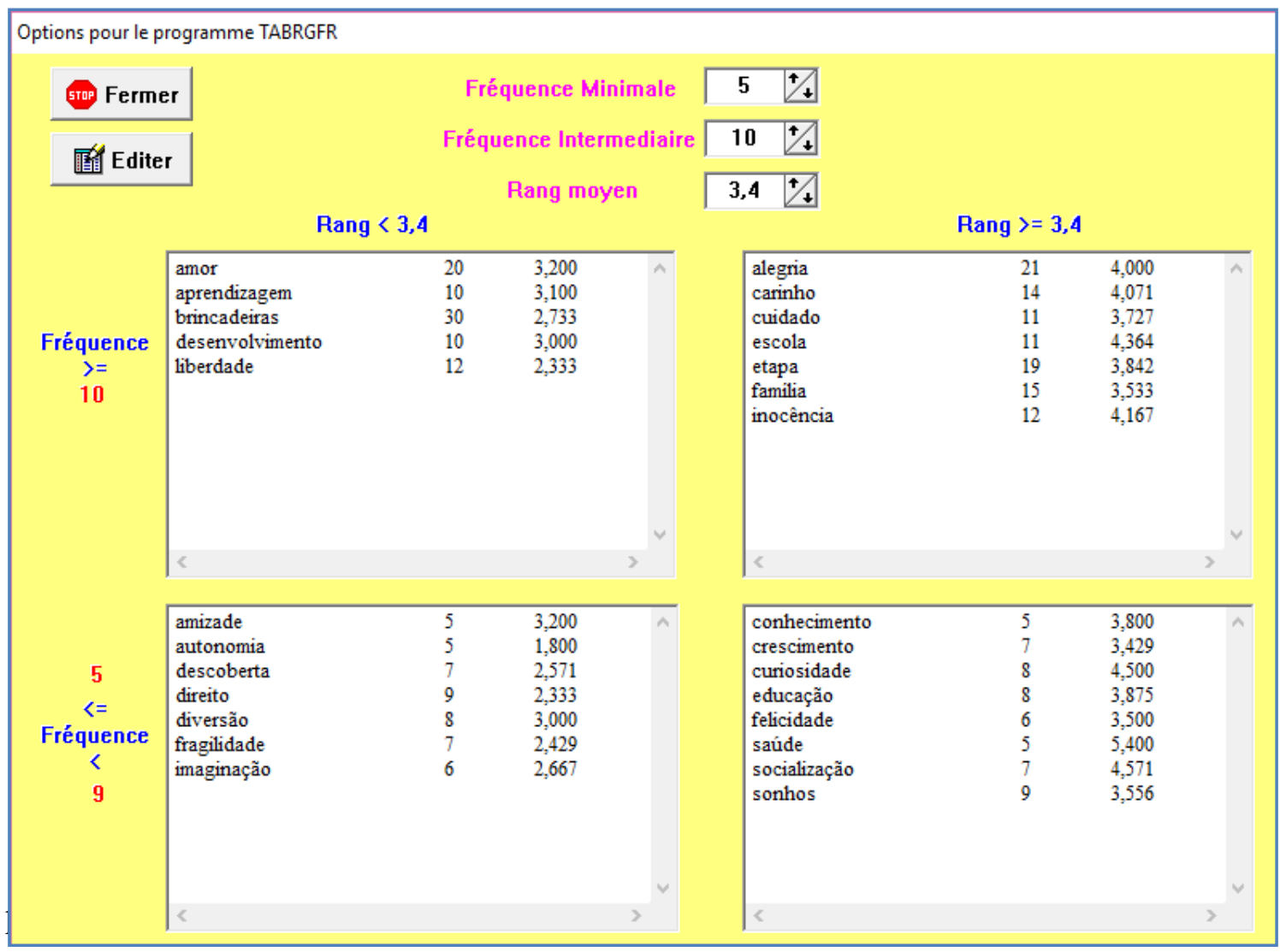


pesquisa sobre a infância. De acordo com a média da frequência e da ordem das palavras, ou expressões, dadas como respostas nos instrumentos das 69 professoras, a palavra "brincadeiras" destacou-se sobre as outras, com 30 ocorrências, seguida, nessa sequência, das palavras "amor", "liberdade", "desenvolvimento" e "aprendizagem". Ressaltamos que foram submetidos a essa análise 414 evocações, referentes à quantidade de respostas dos participantes apresentadas no instrumento ( 6 evocações por participante -69 participantes $=366$ evocações $)$.

Selecionamos as palavras "alegria" e "etapa", dentre as palavras presentes no quadrante superior à direita na mesma figura, por representarem a primeira periferia, ou periferia próxima. Isso significa que ela pode vir a ser o núcleo central também da representação social sobre infância dos participantes, em algum momento.

Os quadrantes inferiores da esquerda e da direita representam a segunda periferia e a terceira, respectivamente, e podem ser chamadas também de periferia distante. $\mathrm{O}$ que significa inferir que os elementos presentes neles estão relacionados ao núcleo central da representação social sobre a infância, mas dificilmente poderão fazer parte dessa parte da estrutura.

A partir dessa descrição, consideramos que a infância, para o grupo de professoras que participou do nosso estudo, é um período em que as brincadeiras estão presentes e fazem parte desse tempo histórico, bem como o sentimento do amor.

\section{Figura 3 - Quadrante Criança}

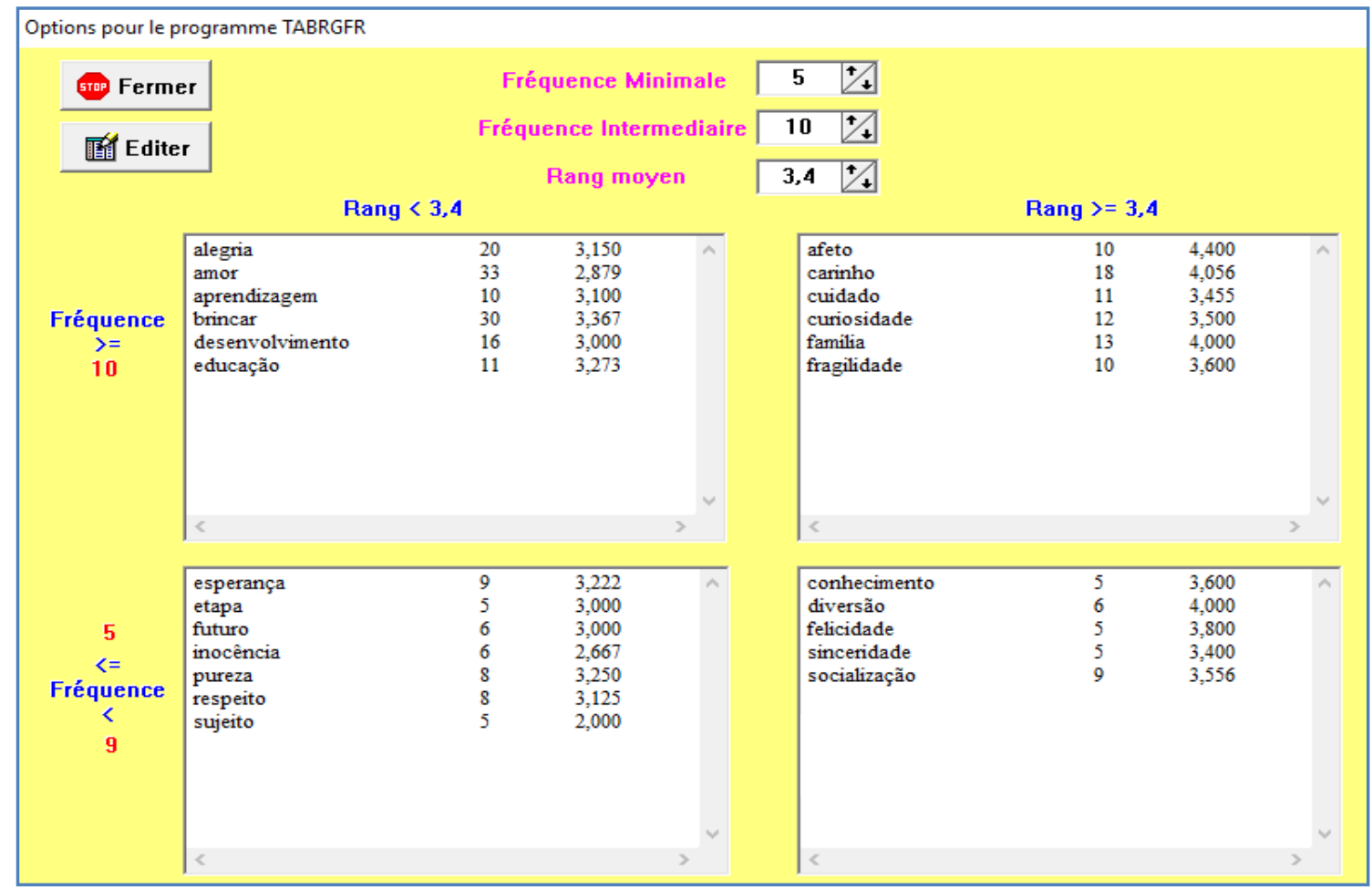


$\mathrm{Na}$ Figura 3, o quadrante superior à esquerda apresenta as palavras "amor" e "brincar" como componentes que se destacam no núcleo central da representação social dos professores participantes da pesquisa sobre o que é ser criança. A primeira e a segunda palavra apresentaram uma elevada ocorrência de evocação e situaram-se entre os termos principais em uma categorização por ordem de importância. As palavras "alegria", "desenvolvimento", "educação" e "aprendizagem" também fazem parte desse nível da estrutura interna da representação, apresentando uma ocorrência expressivamente menor em relação às primeiras.

A palavra "carinho", em relação à representação social sobre criança que esse grupo apresenta também se caracteriza aqui como pertencente à primeira periferia, ou periferia próxima ao núcleo central, por sua frequência de destaque no quadrante. O que permite reafirmar que existe a possibilidade dela integrar, em algum momento, o primeiro quadrante, evidenciando a sua correlação com o núcleo central da representação social.

$\mathrm{Na}$ periferia distante, segunda e terceira periferias, localizadas nos quadrantes inferiores da esquerda e da direita, nessa ordem, aparecem as palavras, ou expressões, "esperança", "etapa", "futuro", "inocência", "conhecimento", "diversão" e "felicidade" como elementos pertencentes a esse nível da representação social.

Esses últimos elementos compõem a representação social das professoras participantes da pesquisa sobre o que é ser criança, contudo não fazem parte do seu núcleo central.

Diante das informações apresentadas nas Figuras 2 e 3, identificamos que para esse grupo estudado não há diferença entre a representação do que é a infância e do que é ser criança. Tendo em vista que, tanto nos quadrantes do núcleo central das representações sociais sobre a infância e criança, as palavras "brincar" e "amor" obtiveram destaque, e as palavras "alegria" e "carinho" surgem como possíveis elementos a ser incluídos nesse nível. Acreditamos que isso acontece porque existe uma aproximação semântica, conceitual, entre esses dois termos; o que permite obter uma leitura menos individualizada feita pelo grupo, que, por sua vez, admite relacioná-los e aproximá-los, corroborando, dessa forma, uma das ideias centrais das representações sociais: elas são uma leitura de mundo e uma rede de significados interligados entre si (MOSCOVICI, 2011). 
Sendo assim, os dados deste estudo mostram que os conhecimentos acerca dessa representação sobre infância e criança remetem a uma representação social das professoras organizada em dois elementos: $O$ brincar e o amor.

Diante do que foi abordado e discutido, buscamos configurar na figura abaixo as representações sociais dos professores dos CEPIs sobre infância e criança, considerando os elementos que apresentaram destaque no núcleo central:

Figura 4 - Interseção entre o núcleo central da representação social da infância e da criança

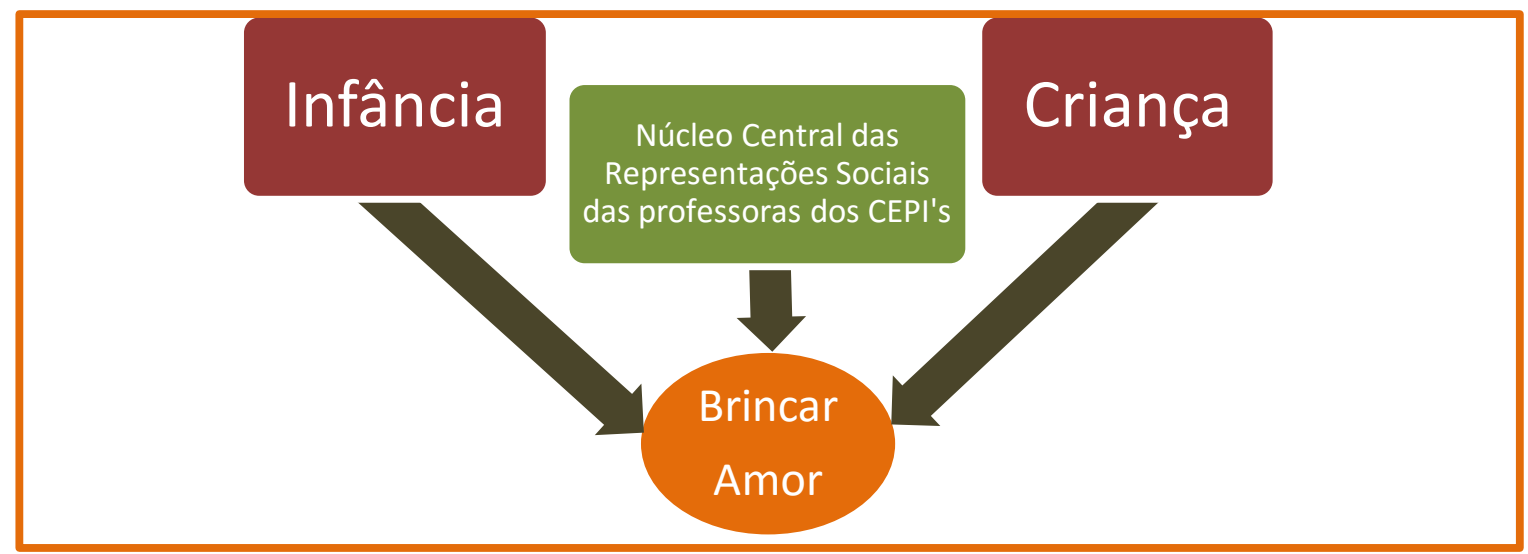

As palavras "amor" e "brincar", como já afirmado e demonstrado anteriormente, foram os elementos de maior destaque no núcleo central da representação social desse grupo de professoras dos CEPIs sobre infância e criança. É um núcleo que está consolidado e dificilmente sofrerá mudança. Acreditamos que esses elementos estão presentes nessa estrutura e se relacionam porque, para esse grupo de professoras, a brincadeira se caracteriza como uma atividade que permite a criança se desenvolver com diversão, liberdade e alegria.

Vigotski (2008) afirma que para apreender os processos de desenvolvimento e, consequentemente, os seus estágios subsequentes, deve-se conhecer de antemão as necessidades das crianças e aquilo que as incentiva, para então colocá-las em ação. Várias são as possibilidades de contribuir para esse processo. Para ele, um bom exemplo disso é a atividade de brincar.

Ele buscou explicar a brincadeira como um processo não exclusivo, mas extremamente relevante para o desenvolvimento da criança; também é importante esclarecer que Vigotski não reduz a brincadeira à simples manipulação de um objeto ou à busca da satisfação do prazer, tendo em vista que outras atividades também podem ser 
prazerosas. Ele afirma que "se não entendermos o caráter especial dessas necessidades, não podemos entender a singularidade do brinquedo como uma forma de atividade" (idem, p.108).

Para ilustrar essa reflexão, seguem as justificativas que as professoras apresentaram em suas respostas aos termos indutores "ser criança é" e "infância é" dos instrumentos de evocação livre de palavras:

\section{Quadro 5}

\section{BRINCAR}

"Toda infância tem que ter brincadeira. A brincadeira ajuda no desenvolvimento da criança." Professora do I período.

"Ter o direito de brincar porque a criança aprende brincando e se torna uma pessoa mais feliz." Professora do I período. "É a hora em que se aprende e constrói conceitos sobre diversos assuntos de maneira prazerosa." Professora do II período.

"Brincar é a vida da criança... sendo a melhor forma para ela se conhecer e conhecer o ambiente em que vive, ou seja, é brincando que se aprende."

"Quando a criança brinca, ela aprende a dividir, interagir, a viver." Professora do II período. Professora do I período.

Fonte: dados da própria pesquisa, 2015.

Vale ressaltar, entretanto, que a brincadeira não é uma atividade exclusiva das crianças, mas sim, própria do ser humano, sendo uma das atividades mais significativas nas relações sociais. Entretanto, ao contrário dos adultos, a criança não distingue o brincar de fazer coisas sérias, sendo esse brincar a coisa mais séria para a criança (Sarmento, 2004). Essa dimensão reafirma a idéia do brincar como trabalho da infância, ou seja, comportamento inerente a esta etapa da vida, contudo a brincadeira parece surgir como momento que a criança tem para "ser criança".

Essa perspectiva parece ser decorrente dos conhecimentos compartilhados pelas professoras dos CEPIs que possuem fontes de informações muitas vezes mais específicas, por exemplo, os conhecimentos científicos decorrentes da formação e experiência da profissão. Jodelet (2001) exemplifica esse aspecto muito bem ao discutir que, apesar da Representação Social ter origem nas condições sócio-estruturais e sóciodinâmicas do grupo, cada indivíduo por dar o seu toque pessoal, uma vez que varia em função das experiências particulares de cada sujeito. Ou seja, cada indivíduo vai formando um sistema de pensamento diferenciado e ao mesmo tempo coerente com o 
pensamento do grupo ao qual pertence, sem que isso entre em conflito com a representação compartilhada.

Já o amor está presente em todas as ações cotidianas das professoras dos CEPIs. Esta representação social sobre infância e criança evidencia a relação estabelecida pelas participantes e a relação que elas fazem com o brincar, por ser um ato que envolve a demanda de trabalho na educação infantil e, diretamente, esse sentimento. Por ter sido muito evocado, podemos dizer que essa característica pertence a uma opinião de caráter mais coletivo (SÁ, 1998). Trata-se, portanto, de uma representação mais comum entre as professoras que têm formação em Educação Infantil.

É importante ressaltar aqui a relação que as professoras fazem quando representam infância e criança com a palavra "amor". Pode-se perceber que a ação educativa, nas respostas das professoras, está cercada por um invólucro romântico onde estão inseridas a infância e a criança. Esse "romantismo" pode ser percebido quando, em suas respostas, as professoras dizem que:

1- “As crianças são de puro amor. Elas não têm maldade, acho que são obras de Deus mesmo e nós temos que ser protetoras delas.”

2- "O amor dedicado a uma criança tem que ser sincero. É um amor divino."

3- "A infância é amor. Deus nos deu esse amor para ajudar as crianças."

Nota-se certa influência dos caminhos percorridos pelas professoras em relação às religiões. Isto nos é apontado na "Caracterização dos sujeitos da pesquisa", sobretudo quando nos diz que $100 \%$ das professoras participantes são Cristãs. Não muito longe, essa representação corrobora com as pesquisas de Arce (2002), quando nos mostra em seus estudos sobre a educação infantil em Pestalozzi e Froebel, que "a doutrina religiosa era, na maioria das vezes, o que mais profundamente as professoras conheciam."

O amor, tantas vezes evocado na história da pedagogia, resumido em uma visão romântica na infância, parece mover as professoras no seu trabalho cotidiano, mais no desenvolvimento de suas atividades e distante da recompensa pela sua dedicação, como se a prática pedagógica com crianças pequenas estivesse restrita ao relacionamento interpessoal em que deveria prevalecer o amor, sem considerar que se exige um profundo conhecimento sobre os diferentes aspectos - físico, emocional, intelectual e social que envolvem o desenvolvimento infantil. 
Segundo Arce :

Vê-se a educação repetir o mesmo papel ideológico que o ideal de família burguesa, infância e maternidade; ignorando-se completamente seu papel histórico, social e político, naturalizam-se as metodologias de trabalho e o papel do professor, que não se caracteriza propriamente como um intelectual. Não por acaso Froebel já considera as mulheres como aquelas que naturalmente estariam aptas para esta função. (ARCE, 2002, p.205).

O quadro abaixo nos mostra, por meio das falas das professoras, em suas respostas aos termos indutores "ser criança é" e "infância é" dos instrumentos de evocação livre de palavras, a relação que elas fazem entre as palavras "amor" e "brincar" e o reflexo dessas representações em seus cotidianos pedagógicos, intimamente ligadas à profissão:

\section{Quadro 6 - Criança, infância e amor}

\section{AMOR}

"Amor é importante para a vida da criança, para seu crescimento e para o desenvolvimento na educação."

Professora do II período.

"Amor que os educandos têm pelos seus colegas na hora das brincadeiras. Também do professor pelos seus alunos."

Professora do I período.

"Eu acho que a primeira coisa que temos que ter para trabalhar com as crianças."

Professora do II período.

"A criança é um sujeito em desenvolvimento que precisa de amor no seu processo escolar."

"Toda criança é amor, ela ama os colegas e a professora. Elas amam brincar."

Professora do II período.

"Amor é importante no nosso trabalho. É a base para o crescimento e desenvolvimento da criança."

Professora do I período.

"Amor é a palavra que abrange todas as outras que escrevi. Através dele a criança tem carinho, brincadeiras e inocência."

Professora do II período.

Fonte: dados da própria pesquisa, 2015.

Alguns elementos não coincidiram de estar no mesmo quadrante, como a palavra "alegria", por exemplo; porém, mesmo estando em espaços diferentes, eles estão presentes na estrutura da representação social. Os elementos que não se repetiram nas 
duas figuras, como "direito", "diversão" e "fragilidade" na segunda periferia do quadrante da primeira figura, "esperança" e "inocência", na figura dois, presentes na segunda figura e na segunda periferia, respectivamente, denunciam uma leve evidência de uma possível diferença entre essas representações; contudo, acreditamos que elas seriam melhor evidenciadas numa abordagem mais aproximativa dos sujeitos participantes do estudo.

$\mathrm{Na}$ tentativa de correlacionar as Representações Sociais, por meio dos elementos evocados, ressaltamos os seguintes pontos teóricos:

1- A representação social não é um simples reflexo da realidade, é uma organização significante que depende de fatores circunstancias (contexto e finalidade da situação) e fatores gerais (ABRIC, 2003);

2- a representação social produz a antecipação dos atos e condutas e a interpretação de uma situação dentro de um sentido preestabelecido e funcionam como iniciadoras de condutas, permitindo suas justificativa em relação às normas sociais (ABRIC, 2003);

3- as prática sociais, independente da discussão de serem determinantes ou determinadas pelas representações, são inerentes a elas (CAMPOS, 2003);

4- as atitudes dependem das representações sociais; assim, mudanças nas representações devem desencadear mudanças de atitude (ABRIC, 2003) e de práticas.

Logo, é correto afirmar que a representação social de um determinado fenômeno determina os valores, os atos e as condutas relacionados a esse fenômeno. Caso a representação seja alterada, isso será percebido nas atitudes e práticas sociais ligadas ao tema da representação.

Dessa forma, é possível supor que a representação social de infância e criança, ancorada nos aspectos lúdicos (o brincar) e afetivos (o amor) possa gerar mudanças no cotidiano pedagógico das professoras dos CEPIs frente a elas. Essa mudança só poderá ser proeminente na promoção de alterações na implementação dos CEPIs, por meio de uma gestão democrática e da reorganização do cotidiano pedagógico, podendo-se até afirmar que a fonte de mudança da representação social poderá vir de dentro da própria estrutura institucional, ou seja, mudanças na organização do trabalho e no conhecimento 
produzido e atribuído a ele. Oliveira (2010) respalda essa ideia mencionando que o processo de educar um indivíduo envolve valores e crenças dos professores, que por sua vez influenciam suas ações e práticas, as quais podem ser facilitadoras ou dificultadoras do desenvolvimento infantil.

Por fim, de forma geral, esse grupo de professoras não diferencia a infância - o tempo histórico vivido - do ser criança - sujeito do tempo histórico, e isso nos chama atenção porque a seu cotidiano pedagógico no CEPI pode estar orientado de modo que elas não percebam ou não considerem relevantes as especificidades, as particularidades das crianças e talvez também não tenham o entendimento da infância como um processo demarcado pelas mudanças e influências sociais.

\section{4 - Terceiro Momento - Análise dos Grupos Focais}

Neste terceiro Momento da pesquisa, com a coleta de dados, buscamos elucidar as definições atribuídas aos elementos que constituem as representações sobre infância e criança. Para isso, optou-se pela formação de dois grupos focais. Essa técnica de levantamento de dados foi feita de maneira grupal, levando a uma expressão de entendimento coletivo (ou não) acerca do objeto de pesquisa. O critério metodológico adotado possibilitou um processo de planejamento em que a composição da pesquisa pudesse gerar depoimentos que pudessem expressar as representações sociais dos professores dos CEPIs sobre Infância e Criança.

Geralmente, os grupos são compostos por pessoas que não se conhecem entre si e a conversa se realiza em lugar equipado de forma devida, destinado para este fim. Porém, os fins a que esta pesquisa se propôs, ou seja, analisar as representações sociais sobre infância e criança dos professores dos CEPIs, foi preciso considerar que o grupo de professoras costuma reunir-se em seus CEPIs ou ainda em capacitações docentes promovidas pelas Coordenações de Educação Infantil de suas respectivas Regionais de Ensino e são as mesmas que já participaram das etapas anteriores da pesquisa, sendo que se apresentaram voluntariamente para participar do grupo focal.

É fundamental destacar o contexto das professoras que participaram dos grupos focais, pois pelo fato de serem colegas de trabalho, e assim já terem estabelecida uma relação afetiva, sentiram-se bem à vontade para compartilhar suas experiências, suas visões e suas lembranças de infância e criança. Nesse clima de familiaridade, até professoras que geralmente são mais tímidas, falaram e expuseram suas vivências e 
opiniões, fortalecendo a discussão do grupo e a construção das representações sociais sobre infância e criança.

Foram então constituídos dois grupos focais, cujos participantes foram decididos entre as próprias professoras, isso porque das 69 (sessenta e nove) professoras participantes do primeiro estudo, 37 se dispuseram a participar voluntariamente dos grupos focais. O pesquisador delimitou de duas a três participantes por CEPI (conforme a quantidade de professoras da unidade). Os grupos focais foram realizados nos dias 19 e 21 de maio de 2015.

Um grupo foi realizado com oito das professoras que atuam nas turmas de I e II períodos da Educação Infantil e aconteceu no período da tarde às quinze horas, não havendo nenhuma desistência por parte das participantes. O outro grupo foi constituído por nove professoras que atuam, também, em turmas de I e II períodos da Educação Infantil e aconteceu às catorze horas. Para comodidade das professoras e melhor organização do pesquisador, ambos os grupos foram realizados na mesma instituição, no CEPI Curió da cidade de Santa Maria.

As participantes chegaram tensas ao local do encontro, porque elas tinham sido informadas sobre a possibilidade de o grupo focal ser gravado e videografado. Em vista disso, optamos somente pela gravação.

Sobre como iniciar uma discussão em um grupo focal Gaskel (2002) sugere que

\footnotetext{
Os moderadores podem usar recursos de livre associação, figuras, desenhos, fotografias e mesmo dramatizações como materiais de estímulo para provocar idéias e discussão, como uma estratégia de fazer com que as pessoas usem sua imaginação e desenvolvam idéias e assuntos. (GASKEL, 2002, p. 80).
}

Com o desejo de que a discussão fomentasse uma conversa tranquila e espontânea sobre infância e criança, contudo produtiva, optamos pela estratégia de exibição de figuras e fotografias com várias situações e cenas com crianças, por meio de slides exibidos em um telão. Esse material apresentou crianças em situações cotidianas da infância, atividades de brincadeiras e criação, destacando sua curiosidade, iniciativa, inventividade e autoconfiança, provocando as professoras a apresentarem seus questionamentos sobre infância e criança.

Nos dois grupos focais, iniciamos a discussão com a pergunta: " $O$ que estas imagens, que vocês estão vendo, nos falam sobre infância e criança?". De início as 
professoras estavam tímidas, mas não demoraram muito a focar no tema infância e criança, tornando a discussão muito rica.

A discussão sobre infância e criança é geralmente uma produção de quem já passou por esta etapa da vida, especialmente neste caso em que a discussão foi realizada por professoras que trabalham com crianças e que atuam diretamente na infância. Conforme Demartini,

[...] são relatos sobre o período da infância, que fazem referências aos períodos da infância vivenciados por cada um. São, portanto, relatos sobre um período da vida que ficou para trás, sobre o tempo da infância que ficou para trás $(2001$, p. 5$)$.

Assim, o grupo focal serviu como técnica que permitiu a sondagem acerca de significados em formulação conceitual sobre infância e criança desses grupos em questão.

As gravações dos grupos focais foram transcritas e recorremos à análise de conteúdo para desvelar o que as falas estariam revelando. Bardin (2002) esclarece que a análise de conteúdo apresenta duas funções complementares: a tentativa exploratória que amplia a descoberta dos conteúdos aparentes e a confirmação ou informação das hipóteses.

No início da atividade dos grupos focais, as professoras revelaram suas tensões nas falas por meio da constante repetição de "né" e "tipo assim". A frequiência desses vícios de linguagem diminuiu conforme o grupo foi se soltando mais na conversa.

A análise dos grupos focais foi organizada em torno dos dois eixos norteadores da pesquisa: Infância e Criança.

Observamos que quando as professoras falaram sobre a infância e criança, observando as imagens projetadas e pensando nas crianças envolvidas em sua prática cotidiana, esta foi considerada diferente daquela presente em suas recordações, pois para a maioria, essa infância e essa criança que se apresentam no chão dos CEPIs não têm a mesma essência daquela vivenciada em suas vidas.

É possível verificar, nas falas das professoras, conforme elucidado nas Análises do Primeiro Estudo, a não diferenciação entre infância e o ser criança. Esses eixos são associados, ambos, às mesmas representações, tanto nas imagens projetadas quanto nas palavras escritas em suas evocações.

Se no primeiro momento optamos pela evocação livre de palavras para identificar objetivamente a representação social dos professores diante da sua exigência em elencar, de forma imediata, as respostas a partir do termo indutor, sem haver a 
possível interferência de elementos que pudessem afetar a construção e compreensão da estrutura dessas representações; nesse segundo momento, pensamos justamente o contrário: clarear quais são os elementos que circundam essas representações que podem ajudar na sua construção e formação da sua rede de significados.

As imagens projetadas trouxeram a ação de brincar de forma intencional, porque encontramos essa atividade associada à infância e à criança nos diferentes espaços e abordagens, tanto no contexto social bem como na área científica. Desde a organização escolar que prevê bastante essa atividade principalmente, se não exclusivamente, para os mais jovens; como também pela sociedade que prevê em seus espaços urbanos parques a céu aberto para as crianças brincarem até determinada idade; sem esquecer a abordagem teórica de Vigotski (2008), conforme apresentamos anteriormente em nosso estudo, que situa essa atividade como importante ação para o processo de desenvolvimento humano.

Dessa forma, esse percurso representa um modo de tentarmos evidenciar se os professores demarcam a infância como algo determinado à priori, que tenha ou possua características específicas, imutáveis, ou se elas têm ou possuem um caráter processual, dinâmico que pode se configurar conforme a experiência que cada um tem ou teve.

Isto posto, os discursos sobre infância e criança, nos grupos focais apresentaram duas categorias básicas desveladas nas falas das professoras: a infância vivida $e$ o brincar. Percebemos aqui uma predominância de elementos comuns, pois as falas das professoras interligavam as categorias. Dessa forma, comparando e relacionado-as, foi possível identificarmos uma convergência entre si.

\subsection{1 - Infância vivida}

As professoras dos CEPIs, adultas que já passaram pela infância, trazem consigo os significados daquilo que viveram neste período da vida, as experiências e os estímulos que recebem e que marcam as habilidades motoras, cognitivas e emocionais. As vivências de sua infância marcam profundamente a imagem que constroem sobre as crianças e a infância, influenciando as suas práticas educativas.

As tensões e os contrastes entre a infância vivida pelas próprias professoras e infância atendida estão presentes nos discursos destas professoras. Nestes discursos emergem diversos temas: as brincadeiras (incluindo os cenários da brincadeira; os tempos de brincar; os brinquedos e o saber brincar). 
A partir dos relatos das professoras, nos debruçamos sobre o que foi abordado por Demartini (2001), que os relatos sobre a infância, fazem referência com os períodos vividos na infância de cada um, sobre um tempo particular que ficou para trás, mas que foi bastante significativo e por isso podem imergir.

Essa categoria aborda elementos do tempo vivido na infância e é fortemente relatado por todos os componentes que participaram do estudo. Em suas falas, as professoras mostram que há uma predominância na relação do conceito do ser criança com as lembranças da própria infância, além de comparações entre as épocas. A nostalgia desse tempo histórico é enfatizada, com melhores condições de ser crianças (entendendo que havia mais liberdade, mais brincadeiras e mais alegria - três elementos citados nas evocações de palavras desvelados no segundo estudo dessa pesquisa). Trazem, também, duas linhas na construção desse conceito. Algumas professoras relacionam a infância com o aspecto de desenvolvimento e crescimento do ser (etapa - elemento que também aparece nas evocações das professoras), relacionando o brincar como função primordial assumida pelo sujeito que vive a infância. E, a outra parte, concebe o tema pelo papel assumido pela sua profissão e pelas cobranças e necessidades inerentes à profissão. Podemos observa nas falas das professoras, transcritas abaixo:

\section{Quadro 7. O brincar como função primordial assumida pelo sujeito que vive a} infância

"Falar sobre infância é sempre um prazer pra mim.Sempre me reporto a minha que foi muito significativa, como também procuro fazer um trabalho com minhas crianças nesse sentido. É preciso brincar, se envolver nas brincadeiras, dar vida a elas". (Professora do berçário II).

"Minha infância me traz muitas lembranças, mas qual me faz lembrar com alegria é do tempo em que brincava de Escolinha com minhas amigas." (Professora do I período).

"Quando você começou a passar as imagens sobre a infância, com crianças, logo veio na mente a minha infância: uma infância cheia de alegrias, pois sempre estava toda a família unida, meus pais querendo o melhor para os filhos; quando era bebê todos queriam me pegar no colo, mimar, acariciar e eu sentia uma felicidade enorme, sempre sorridente, batia palmas para as fotos, todos me achavam muito fofinha e bonita e dessa infância que eu lembro com muito carinho, claro que tinha medo de enfrentar os desafios do dia-a-dia, descobrir coisas novas, mas sempre encontrava apoio, proteção da família que eu amo muito! Aqui no CEPI que trabalho, vejo que as crianças não têm mais isso. Elas não têm amor! E criança é amor, é isso!" (Professora do I período).

Fonte: dados da própria pesquisa, 2015.

Essas características na construção da representação social de infância e criança reafirmam o fato de a infância ser uma categoria construída socialmente e não 
naturalmente (KRAMER, 2006). O conceito que se tem ou se formula depende das representações que o próprio adulto faz sobre o período inicial da vida, ou seja, são as próprias lembranças, aqui, que vão determinando o que pensam de infância e criança. Logo, vai variar em função das relações entre as interações sociais e o ambiente próprio de cada sociedade (SARMENTO, 2004; SIROTA, 2001). Da mesma forma, a representação também varia em função de como a sociedade enxerga o lugar social da criança (MORO e GOMIDE, 2003) e se organiza em cima dela (KRAMER, 2006; SIROTA, 2001).

As falas das professoras, também possuem uma conotação teórica (termos que remetem a ideia de desenvolvimento, crescimento físico), caracterizada pela formação especializada e, por uma visão quanto ao papel do profissional, provavelmente em decorrência das expectativas geradas pela atual organização da Educação Infantil e do crescente valor assumido. Costa e Almeida (2000) estimam que o reconhecimento que o professor tem de seu papel, interfere na construção de sua identidade profissional e consequentemente, no seu cotidiano pedagógico.

Podemos perceber nos discursos também a ideia de vir-a-ser, expressando a visão da criança como um projeto futuro, aberto a todas as possibilidades, tanto de sucessos quanto de fracassos. São complementadas por outras imagens que traduzem as ideias implícitas sobre a socialização da criança - que deve ser guiada pelos adultos para que as suas possibilidades sejam de sucesso e não de fracasso, tal concepção revelada por meio das falas das professoras ao que Rousseau também preconizou, da qual o preceptor (quem cuidava da educação em sua época) tinha como função orientar e dirigir a criança àquilo que lhe é natural (ARCE, 2002).

É importante ressaltar que esta caracterização foi produzida por 12 (doze) das 18(dezoito) professoras participantes do grupo focal.

\section{Quadro 8. O "vir-a-ser"}

"Na nossa infância a gente tinha sempre alguém que ajudava e cuidava. Como que as crianças de hoje terão futuro se elas estão largadas a cada dia?" (Professora do II período)

"Quando eu era criança eu queria ser professora. Brincava de escolinha. Muitos dos meus amigos de vizinhança tinham uma idéia do que queriam ser quando crescer. Espero que meus alunos pelo menos sejam amados e felizes, né?" (Professora do berçário I)

"A infância de hoje está perdida! É preciso que essas crianças tenham mais atenção da sociedade, senão elas não serão nada na vida. Na nossa infância tinha uma perspectiva de futuro." (Professora do I periodo)

Fonte: dados da própria pesquisa, 2015. 
Neste sentido, essa caracterização corrobora o pensamento de Qvortrup (2005) quando assinala que a dubiedade do conceito de socialização em sua "tendência de antecipação": em termos de desenvolvimento individual, a socialização olha, por definição, "em frente", afastando-se da infância e refletindo assim a idéia desta etapa da vida como o desenvolvimento precoce de uma cultura de adultos. O que disto resulta é a visão da criança não como um ser nele mesmo, com direito a um reconhecimento próprio, um ser "no presente", mas um ser "em devir", um ser "no futuro" cuja existência passa a representar a "passagem" em direção à vida adulta (JAMES e PROUT, 1997).

Consideramos essas questões como aspectos sociais, demarcadas em expressões como "perspectiva de futuro", "relação social", "brincar de escolinha", demonstrando, dessa forma, que a infância tem uma carga social e depende de outros elementos como a interação social, a ideia de depender do outro para compreender as regras sociais e, talvez, a ideia dos direitos e deveres das crianças.

Uma caracterização nova que apareceu nessa etapa do estudo foi relacionada à constituição da criança como ser social situado histórica e culturalmente, com sentimentos, afetividades e visto de forma pura, sem maldades, reforçando talvez a ideia de que é a sociedade que corrompe o homem, conforme afirmado por Rousseau (TARDIF, 2012). Outra informação importante que emerge na questão sobre a infância e criança diz respeito ao fato de se entender a criança como um ser que pensa, que possui a sua singularidade uma vez que tem a sua maneira própria e pessoal de estar no mundo.

\subsection{2 - O brincar}

De acordo com a discussão no primeiro estudo da pesquisa que caracterizou o núcleo central da representação social das professoras dos CEPIs, o brincar é um dos elementos mais importantes, senão o mais importante, do núcleo central, de tal forma que o brincar se torna a significação da imagem da infância e da criança. No entanto, na constituição da infância vivida pelas professoras, os brinquedos e as brincadeiras, contextualizados social e culturalmente, constituem elementos importantes e que encontram ressonância no cotidiano pedagógico. 
Desta forma, os discursos em torno do tema brincadeiras revelam uma permanente tensão entre o que foi a infância das professoras e o que é a infância das crianças que elas recebem nos CEPIs.

Aparecem, assim, comparações da própria infância com a das crianças, salientando suas diferenças, tanto nos tipos de brincadeira, quanto no espaço físico e na segurança de brincar na rua, relatando ainda o desejo de que as crianças vivenciem algumas experiências da infância vivida pela professora.

Os discursos transcritos abaixo revelam essa perspectiva acerca das experiências vividas.

\section{Quadro 9. Perspectiva acerca das experiências vividas}

"Eu noto que as brincadeiras realizadas pelas crianças hoje são diferentes pelo fato de algumas crianças morarem em apartamentos e condomínios, acho que isso dificulta por ficar mais fechada e também pela questão das crianças hoje já estarem se inserindo muito cedo na escola." (professora do I período).

A criança é feita pra brincar! Subir em árvores, por exemplo, ainda não vi uma criança que não goste! Brincadeiras de bola e de esconder, também lembram a infância, assim como joelho roxo ou esfolado. Na infância tudo parece mais colorido e divertido e os problemas são do tamanho do nosso tamanho. Infância é brincadeira (Professora do II período).

As brincadeiras mais prazerosas eu vivi na minha infância. Meus avós maternos faziam uma roça para cultivar arroz todos os anos e quando chegava a época da colheita a família reuniase para realizá-la. Todos ajudavam até nós crianças (eu e meus primos). Depois de cortado o arroz era batido num caixote e a palha era jogada toda num lugar só formando uma verdadeira montanha de palha seca, então vinha a melhor parte embalar, correr e pular em cima, se jogar sobre ela até abaixar a montanha. Que delícia belos tempos, tempos que ficam eternamente na lembrança de uma infância maravilhosa. Hoje as crianças não têm infância. (Professora do I período).

"Quando vejo essas imagens que mostra sobre a infância, eu lembro que brincava com meu irmão e amigos em casa depois que chegava da escola, brincava de pular corda, de pega-pega, de fazer cabana com bambu, subir em árvores e colher goiaba, jabuticaba e outras frutas, era bem divertido. A criança era diferente. Mas hoje vejo que as crianças não brincam mais destas coisas saudáveis, só querem computador, jogos eletrônicos (Professora do II período).

Fonte: dados da própria pesquisa, 2015.

O cotidiano pedagógico e a rotina lúdica aparecem como fatores relevantes da Educação Infantil. Aspectos relacionados às brincadeiras na escola são mencionados pelas professoras dos CEPIs. Apesar das mudanças pedagógicas e estruturais da educação infantil (BRASIL, 2006), o aspecto do brincar ainda é muito presente.

Essa categoria, no caso das professoras, aparece como elemento principal da representação de infância e criança e, sobretudo, como instrumento para seu desenvolvimento e aprendizagem, revelando que o brincar está presente no cotidiano das infâncias - de ontem e de hoje - e é inerente à condição de criança. Contudo, a 
relação entre o brincar e o sentimento amor - revelados como núcleo central das representações sociais nas evocações das professoras no primeiro estudo - está presente de forma explícita nos discursos. Essas representações compartilhadas pelo grupo, são exemplos de toques pessoais de indivíduos ou sub-grupos dentro da amostra (JODELET, 2001).

\section{Quadro 10. O brincar e o sentimento amor}

A criança é amor! Lembro das coisas gostosas e me dá saudade. O fogão a lenha, repleto de gostosuras, muitos amigos e brincadeiras, banhos de rio, natureza, histórias contadas pelos pais, tios e avós (até histórias de terror), cantigas de roda e muitos objetos (diversos) utilizados para o faz-de-conta imitando os adultos e outras crianças (Professora do berçário II).

Fonte: dados da própria pesquisa, 2015.

É possível extrair, da fala das professoras dos CEPIs, que o brincar prevê a utilização de práticas agradáveis e adequadas às crianças - isto fortemente ancorado nas suas experiências - capazes de proporcionar o aprendizado das coisas que lhes são importantes e naturais e que respeitam as características próprias das crianças, seus interesses e esquemas próprios de raciocínio. Ainda, segundo as professoras dos CEPIs, o brincar traz alegria, desenvolvimento e ajuda nas aprendizagens.

No entanto, Vigotski (2008) destaca ainda, que nem sempre o brincar será prazeroso, pois em alguns momentos a criança enfrentará situações de frustração. Alguns jogos durante a sua realização, não proporcionam prazer, ou proporcionam prazer se o resultado for interessante para a criança, como por exemplo, na apropriação da cultura do mundo adulto, por meio dos jogos que dominam o final da etapa préescolar e o início da escolar, denominados como jogos esportivos.

Dessa forma, podemos afirmar que ao mesmo tempo em que as crianças se apropriam da cultura do mundo adulto também constroem a sua própria cultura e o brincar é um espaço privilegiado para que isso aconteça (o que podemos verificar na fala das professoras quando relatam as experiências da infância).

Quando brincam livremente as crianças têm liberdade de decidir como e com quem vão brincar e de que maneira as brincadeiras serão realizadas de acordo com suas características físicas, podendo assumir as funções que os brincantes acharem mais convenientes naquele momento. Pois, de acordo com Corsaro (2011, p.145) "à medida que as crianças desenvolvem-se como indivíduos, elas se apropriam coletiva e criativamente, usam e introduzem aos brinquedos significados, tanto na família quanto em suas culturas de pares". 
Considerando que crianças e adultos pertencem a diferentes categorias geracionais cujas atitudes estão permeadas pela linguagem, interesses e necessidades específicas de cada um, torna-se necessário fazermos uma investida sobre a compreensão das falas das professoras dos CEPIs que sinalizam que as representações sociais são construídas ainda na infância. Nesta perspectiva Duveen (2011) ressalta que:

Se examinarmos os processos através do quais as crianças incorporam as
estruturas do pensamento de sua comunidade e adquire assim um lugar como
participante competente e funcional nessa comunidade, eles nos apresentam
um campo de investigação que pode ser fontes de questões produtivas e
contribuições construtivas para a própria TEORIA DAS
REPRESENTAÇÔES SOCIAIS. (DUVEEN, 2011, p. 209).

Nessa perspectiva, Duveen (2011) ressalta que se nós quisermos entender as representações sociais, precisamos entender os processos através dos quais elas são produzidas e transformadas. Dessa forma, as professoras demonstram nesse estudo que reconhecem as crianças enquanto cidadãs portadoras do direito de brincar, sendo possível apreender as representações sociais construídas por esses sujeitos participantes da pesquisa, pois "todo ator social tem uma história de desenvolvimento, cuja influência não pode ser ignorada" (DUVEEN, 2013, p. 210).

Deste modo, no grupo das professoras dos CEPIs, começa a ser gerada a significação de infância e criança, ancorada nas experiências das professoras enquanto crianças: para as professoras, se na sua infância o lar, o seio da família era o espaço da criança, da brincadeira e a escola era o espaço da responsabilidade, do deixar de ser criança, atualmente acontece o inverso: a escola (mais especificamente a instituição de Educação Infantil) é o único ambiente em que se pode brincar, ser criança, cabendo às professoras o apoio às brincadeiras infantis. 


\section{CONSIDERAR PARA NÃO CONCLUIR}

Enveredar por um estudo que busca representar a infância e a criança é uma atividade que desperta sentimentos diversos. Em um primeiro momento podemos pensar que versar sobre infância e criança é, de certa forma, uma tarefa fácil ou simples por se tratar de conceitos que representam um ser humano em uma etapa de vida tão comum e concernente a todos. Podemos perceber que a possibilidade de nos deparamos com essas representações está muito presente no nosso cotidiano; nas relações sociais que participamos, quando passamos em frente a uma escola, quando encontramos com as crianças na vizinhança, percebemos que sempre nos encontraremos em uma situação de ficar frente a frente com uma criança. Mesmo na circunstância dela fazer parte das nossas relações pessoais ou não, percebemos que, acima de tudo, independentemente da relação que temos, já possuímos uma ideia sobre ela.

Porém, quando buscamos refletir sobre os elementos que fazem parte do universo da criança, como elas se comportam, pensam, aprendem e se desenvolvem, pensamos quase que automaticamente em uma pessoa que desempenha um papel primordial, durante um longo período da sua vida, nesses processos complexos na e da sua formação: o professor.

Sendo assim, ressaltamos aqui as representações sociais, uma vez que estão ligadas a sistemas de pensamento mais largos, ideológicos ou culturais, e a um estado de conhecimentos científicos. As instâncias institucionais, os meios de comunicação mediáticos ou informais intervêm na sua elaboração, por meio de processos de influência social (JODELET, 2001). Nesse contexto, a proposta do estudo buscou analisar as representações sociais das professoras dos CEPIs sobre a infância e criança.

$\mathrm{O}$ caminho exposto nesta pesquisa teve como foco a análise de uma realidade social que tem sido negligenciada e pouco estudada. Cuja representações são compreendidas como um espaço/tempo dinamizado pelas relações sociais e pelas tentativas de explicação do mundo pelas ações e falas dos indivíduos e dos objetos sociais, advindas da realidade do senso comum, que conferem um novo valor ao pensamento social e constituem-se em representações sociais.

No atual contexto de transformações sociais, em que emergem debates e questionamentos quanto aos diferentes espaços pensados para a primeira infância, foi de grande relevância analisar as representações sociais sobre infância e sobre criança das professoras dos CEPI's, por meio de subsídios teórico-práticos que sinalizaram 
caminhos possíveis para a (re) significação do cotidiano pedagógico dos CEPIs articulado à complexidade do mundo contemporâneo.

O envolvimento das professoras dos CEPIs, as situações e ações emergidas no contexto da pesquisa, apresentaram alguns desafios epistemológicos e metodológicos que foram encarados como a possibilidade de compreender o processo de pesquisa em sua dialética. Desafios que se expressaram na necessidade de:

1- Perceber o espaço CEPI como um espaço/tempo onde emergem questões complexas e inusitadas, que exigiram revisões permanentes do referencial teórico.

2- As ideias do que se desvelou implícito nas falas, ações e gestos, pois representaram ricos elementos para análise.

3- O respeito à história de vida e de construção das aprendizagens de cada professora participante da pesquisa.

Em relação ao conteúdo das representações, pressupõe-se que as evocações induzidas pela utilização da técnica de associação livre são os elementos que constituem o conteúdo do campo da representação das professoras dos CEPIs. A análise das evocações revelou que estes elementos se referem a brincadeiras, amor, alegria, etapa de vida, desenvolvimento e aprendizagem. No entanto, para conhecer uma representação social, não basta identificar o seu conteúdo. É necessário também conhecer como ele se organiza e qual a sua dinâmica, o que se procurou contemplar nas questões seguintes.

Verificamos que, no grupo de evocações do núcleo central da representação, a categoria que emerge das evocações é o brincar (tempo vivido e as brincadeiras) e o amor são os principais aspectos para que o desenvolvimento aconteça, revelando uma imagem de criança no sentido psicológico.

O brincar se apresentou como elemento constitutivo do núcleo central das representações sociais tanto da infância como da criança. Em ambos, obteve maior destaque diante do número de ocorrências e também por sua ordem de importância. Questionamo-nos quanto à sua relevância para o professor. Será que ele se utiliza do brincar e da brincadeira como uma das formas de conhecer o seu aluno? Ele promove o brincar como estratégia para compreender, promover o desenvolvimento e se relacionar com ele? Diante das falas apresentadas, observamos que elas identificam que o brincar é importante para a aprendizagem, principalmente para aquelas que se referem ao 
reconhecimento e à ludicidade nos espaços educativos. Contudo, mesmo reconhecendo a importância do brincar na infância, as professoras ainda encontram dificuldades para promover momentos de brincadeiras entre as crianças no cotidiano pedagógico, seja como meio que favorece o desenvolvimento ou apenas como forma de atividade para ocupar o tempo.

Esse aspecto nos fez refletir sobre a função orientadora dessas representações. A Pesquisa permite sugerir a necessidade de aprofundar e dar continuidade ao estudo, considerando que o cotidiano pedagógico das professoras e, consequentemente, a sua interpretação e compreensão do universo infantil são orientados pela ideia que elas possuem acerca das crianças. Pode-se pensar então de que maneira elas organizam o seu trabalho e em função do quê: a criança é o centro da sua ação? De que forma? Seriam essas questões relevantes para estudos futuros.

Já no sistema periférico que tem a função de proteger o núcleo central foi possível identificar três níveis periféricos. No primeiro nível periférico, destacaram-se os contextos da infância e criança como alegria, carinho e etapa. No segundo nível periférico estão as evocações que remetem às reminiscências e os direitos na infância. No terceiro nível periférico foram encontradas evocações relacionadas às vivências pessoais das professoras.

Para compreender as negociações entre os diferentes significados que impregnam os conteúdos da representação social, foram realizados dois grupos focais. A utilização desses focais revelou-se um instrumento fundamental para esta pesquisa, porque permitiu que compreendêssemos a dinâmica da representação social.

O núcleo central revela que a representação de infância e criança se objetiva em uma imagem de crianças brincando, no qual os significados de brincadeira se fundem com o significado de infância e de ser criança, o que sugere que, esta imagem ainda é dominada pela criança idealizada, sob uma forma romântica do tempo vivido. É também uma imagem criada com base nos conhecimentos das professoras sobre desenvolvimento infantil, adquiridos em suas formações inicial e continuada. Assim, o significado de infância e criança se materializa nesta imagem de criança, no sentido psicológico. Os conteúdos que constituem os sistemas periféricos, entretanto, revelam que outras significações começam a emergir, significações estas que estão ancoradas nas experiências das professoras nos CEPIs e nas recordações de suas próprias infâncias. 
A constatação de que o contexto social mudou e que as crianças de hoje já não realizam as mesmas atividades (brincadeiras), tem um espaço previamente delimitado nas relações sociais, levando as professoras a concluir que a infância está ameaçada de extinção, conforme defendido por Postman (1999).

Desta forma, os diferentes significados que são tecidos nas representações das professoras são negociados em torno de dois eixos principais: o tempo vivido e o brincar. Assim, as professoras constroem uma representação de si mesmas e da educação infantil com essas representações ancoradas na própria experiência de vida.

Tornam-se, assim, sujeitos de uma infância saudosista e romântica onde educação infantil constitui-se como um mundo à parte, onde pode tudo (em termos de inventividade), tudo vale (brincar, se sujar, fantasiar...), recuperando o valor de "ser professora de educação infantill", o que as fortalece enquanto profissionais em uma sociedade em que a profissão de professora é cada vez mais desprestigiada.

Identificamos que estas representações são fortalecidas, também, nas formações acadêmicas e docentes voltadas para a educação infantil, no que diz respeito à importância da brincadeira para a criança e, ao mesmo tempo, contribuem para que as professoras construam e assumam suas identidades profissionais.

Os depoimentos acerca das infâncias vividas por estas professoras, o prazer e a satisfação e até mesmo os relatos sobre as coisas que não gostam de fazer na rotina pedagógica, com as crianças, revelam que o cotidiano nos CEPIs é efetivamente determinado por suas representações sobre a infância e criança e sobre os contextos da educação infantil. Por outro lado, o brincar e o sentimento de amor parecem fortalecer a imagem da Educação Infantil como um ambiente de preservação de algumas culturas infantis cristalizadas nos espaços dos CEPIs - mesmo que o brincar, enquanto cultura infantil, ainda seja definido sob o ponto de vista delas, alicerçado na imagem delas mesmas quando crianças.

Portanto, a representação de infância e criança das professoras dos CEPIs/DF está baseada numa imagem de criança num sentido psicossocial, com uma preocupação voltada para o desenvolvimento por meio da discussão nos grupos focais em que aprofundaram suas reflexões a partir das suas próprias infâncias, com as marcas que estas deixaram e, em comparação com as infâncias que observam hoje nas suas experiências de trabalho ampliou para uma discussão, cuja tônica está na preocupação com as culturas infantis que julgam estar se perdendo. Isto denota uma evolução de uma "infância-criança" num sentido psicológico para uma "infância-crianças" no sentido 
sociológico, importando para as professoras um resgate da infância e da criança com base no tempo histórico vivido por elas. 


\section{REFERÊNCIAS}

ABRIC, Jean-Claude. A abordagem estrutural das representações sociais. In: MOREIRA, Antonia S.; OLIVEIRA, Denise C. (Orgs.). Estudos interdisciplinares de representação social. Goiânia: AB Editora. 1998.

Abordagem estrutural das representações sociais: desenvolvimentos recentes. In: CAMPOS, Pedro Humberto F.; LOUREIRO, Marcos C. da (Orgs.). Representações sociais e práticas educativas. Goiânia: UCG, 2003. p. 37 - 57.

A zona muda das representações sociais. In: OLIVEIRA, Denise C.;

CAMPOS, Pedro Humberto F. Representações sociais: uma teoria sem fronteiras. Rio de Janeiro: Museu da República, 2005. p. 23 - 34. (Coleção Memória Social).

ALMEIDA, Angela de Oliveira; CUNHA, Gleicimar Gonçalves. Representações

Sociais do Desenvolvimento. Psicologia: Reflexão e Crítica, 2003, 16(1), p. 147 - 155. Disponível em: www.scielo.br/pdf/prc/v16n1/16806. Acessado em 12/07/2015.

ALMEIDA, A.M.O. A pesquisa em representações sociais: fundamentos teóricometodológicos. Ser social, 9, 2001. p. 129 - 158.

ALVES-MAZZOTTI, Alda Judith. A abordagem estrutural das representações sociais. In: Psicologia da Educação, Revista do Programa de Estudos Pós-Graduação PucSP, n. 14-15, 2002.

ARCE, A. A pedagogia na era das revoluções: uma análise do pensamento de Pestalozzi e Froebel. Campinas: Autores Associados, 2002.

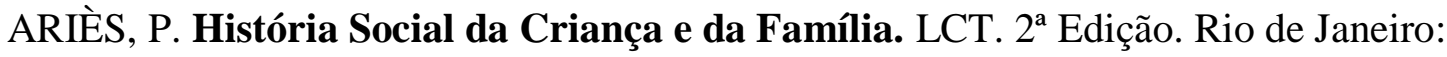
Livros Técnicos e Científicos. Editora S.A., 1981.

BALDWIN, Alfred L. A teoria de desenvolvimento da criança. São Paulo: Pioneira, 1973.

BIAGGIO, Angela M. Brasil. Psicologia do Desenvolvimento. Vozes editora, 15 ed, Petropoles: 2001.

BARDIN, Laurence. Análise de conteúdo. Lisboa: Edições 70, 2002.

BANCHS, María Auxiliadora. Representaciones sociales en proceso: su análisis através de grupos focales. In: MOREIRA, Antonia Silva Paredes (org.). Perspectivas teórico metodológicas em representações sociais. João Pessoa: Editora Universitária UFPB, 2005 , p.573- 603 .

BERGER, K. S. O Desenvolvimento da Pessoa: da infância à adolescência. Rio de Janeiro: LTC editora, 2003.

BERGER, P. L.; LUCKMANN, T. A construção social da realidade. $35^{\mathrm{a}}$ ed.

Petrópolis: Vozes, 2013. 
BRASIL. Senado Federal. Lei de Diretrizes e Bases da Educação Nacional: $n^{\circ}$ 9394/96. Brasília: 1996.

Senado Federal. Consolidação das Leis do Trabalho. Decreto-Lei no 5.452/43. Brasília: 1943.

CORSARO, W. Sociologia da Infância. Tradução: Lia Gabriele Regius Reis; revisão técnica: Maria Letícia B. P. Nascimento. - Porto Alegre: Artmed, 2011.

CERIZARA, Ana Beatriz. Rousseau: a educação na infância. São Paulo: Scipione, 1990.

CORSARO, W. Reprodução interpretativa e cultura de pares. In: MÜLLER, F. e CARVALHO, A.M.A (Org). Teoria e prática na pesquisa com crianças: Diálogos com William Corsaro. São Paulo: Editora Cortez, 2009. p. 31 - 50.

COSTA, Wilse Arena da; ALMEIDA, Ângela Maria de Oliveira (2000). Teoria das representações sociais: uma abordagem alternativa para se compreender o comportamento cotidiano dos indivíduos e dos grupos sociais. Revista de Educação Pública. Disponível em http:/www.ufmt.br/revista/arquivo/rev13/ assessado em $14 \mathrm{de}$ abril de 2015.

DELGADO e MÜLLER, F. Em busca de metodologias investigativas com as crianças e suas culturas. SP. Cadernos de Pesquisa. Vol. 35. No 125. 2005. p. 171 179.

DEMARTINI, P. Contribuições da sociologia da infância: focando o olhar.

Florianópolis: Revista Zero-a-seis. 2001. Disponível em:

http://www.ced.ufsc.br/zeroseis/artigos6.html.

DEMATHÉ, T. M. e CORDEIRO, M. H. Representação social de professoras de educação infantil sobre infância: algumas considerações. GT: Educação de Criança de 0 a 6 anos /n.07, 2000.

DISTRITO FEDERAL. Secretaria de Estado de Educação. Currículo em Movimento da Educação Básica. Educação Infantil. Brasília, DF: 2014.

Orientações Pedagógicas para a Educação Infantil / SEEDF. Brasília,

DF: 2014.

DOTTA, L. T. Representações Sociais do ser professor. Campinas, SP: Editora Alínea, 2006.

DURKHEIM, E. Educação e sociologia. São Paulo: Melhoramentos, 1978.

DUVEEN, G. Introdução: o poder das idéias. In: - Moscovici, S. Representações sociais: investigações em psicologia social. - Petrópolis: Vozes, 2011. p. 07 - 28.

DUVEEN, G. Crianças enquanto atores sociais: as Representações Sociais em desenvolvimento. In: - GUARESCHI, Pedrinho e JOVCHELOVITCH, Sandra. (Orgs); Texto em Representações Sociais. - Petrópolis: Vozes, 2013. p. 209 - 238. 
FARR, R. M. Representações Sociais: a teoria e sua história. In: - GUARESCHI, P. e JOVCHELOVICTH, S. Textos em representações sociais. - Petrópolis: Vozes, 2013. p. $27-52$.

FREIRE, Paulo. Pedagogia do Oprimido. Rio de Janeiro: Paz e Terra, 2005, 42. ${ }^{\mathrm{a}}$ edição.

GASKELL, George. Entrevistas individuais e grupais. In: BAUER, M. W.; GASKEL, G. Pesquisa qualitativa com texto, imagem e som. Petrópolis: Vozes, 2002, p. 64 89.

GATTI, Bernadete Angelina. Grupo focal na pesquisa em ciências sociais e humanas. Brasília: Liber Livro Editora, 2005.

DISTRITO FEDERAL, Administração Regional de Santa Maria, RA -XIV. Disponível em: http://www.santamaria.df.gov.br, acessado em maio de 2015.

DISTRITO FEDERAL, Administração Regional do Recanto das Emas, RA -XIV. Disponível em: http://www.recantodasemas.df.gov.br, acessado em maio de 2015.

GIL, A. C. Métodos e técnicas de pesquisa social. $6^{\text {a }}$ ed. - São Paulo: Atlas, 2008.

GILLY, Michel. As representações sociais no campo da educação. In: JODELET, Denise (Org.). As representações sociais. Rio de Janeiro: Eduerj. 2001.

GONDIM, S. M. G. Grupos focais como técnica de investigação qualitativa: desafios metodológicos. Bahia: Paideia, v.12, n. 24, 2003, p. 149 - 161. Disponível em: http://www.scielo.br/pdf/paideia/v12n24/04.pdf. Acessado em 15 de agosto de 2014.

JAMES, A.; PROUT, A. A new paradigm for the sociology of childhood?: provenance, promise and problems. In: JAMES, A.; PROUT, A. Constructing and reconstructing childhood. London: Falmer, 1997.

JAVEAU, C. Criança, infância (s), crianças: que objetivo dar a uma ciência social da infância? In: Educação e sociedade, v. 26, maio/ago, 2005, p. 379 - 389.

JODELET, D. Contribuições das representações sociais para a análise das relações entre educação e trabalho. In: PARDAL, L. et al. (Org.). Educação e trabalho:

representações, competências e trajetórias. Aveiro: Universidade de Aveiro, 2007. p. $11-26$.

D. Representações Sociais: um domínio em expansão. In: JODELET, Denise (Org.). Representações Sociais. Rio de Janeiro: Ed. UERJ. p. 11 - 44, 2001.

JOVCHELOVITCH, S. Vivendo a vida com os outros: intersubjetividade, espaço público e representações sociais. In: JOVCHELOVITCH, Sandra; GUARESCHI, Pedrinho. (Org.) Textos em representações sociais. Petrópolis, RJ: Vozes. 2013. p. 53 -72 .

KISHIMOTO, Tizuko Morchida. e PINAZZA, Mônica Appezzato. Froebel: uma pedagogia do brincar para a infância. In: OLIVEIRA-FORMOSINHO, Júlia e outros 
(org.). Pedagogia(s) da infância: dialogando com o passado: construindo o futuro. Porto Alegre: Artmed, 2007.

KRAMER, Sonia. A infância e sua singularidade. In: BRASIL, Ministério da Educação. Ensino fundamental de nove anos: orientações para a inclusão da criança de seis anos de idade. Ministério da Educação. Secretaria de Educação Básica. Departamento de Educação Infantil e Ensino Fundamental. Brasília: FNDE, Estação Gráfica, 2006, p. 13 $-23$.

LANE, Silvia Tatiana Maurer. Usos e abusos dos conceitos de representação social. In: SPINK, Mary Jane P. (orgs.) O conhecimento no cotidiano: as representações sociais naperspectiva da psicologia social. São Paulo: Brasiliense, 1995, 58 - 71.

LUDKE, M. e ANDRÉ, M.E.D.A. Pesquisa em educação: abordagens qualitativas. São Paulo: EPU, 1986.

MACHADO, Maria de Lucia de A. (org). Encontros e desencontros em educação infantil. São Paulo: Cortez, 2000.

MADEIRA, M. Representações sociais e educação: importância teórico-metodológica de uma relação. In: PAREDES, A. (org.). Representações sociais: teoria e prática. João Pessoa: Ed. da UFPB, 2001. p. 411 - 440.

MELO, G. N. de. Formação inicial de professores para a educação básica: uma (re)visão radical (versão preliminar para discussão interna). São Paulo: texto, outnov/1999.

MIZUKAMI, Maria da Graça N. Ensino: as abordagens do processo. São Paulo: e.p.u, 1986.

MONTANDON, C. Sociologia da infância: balanço dos trabalhos em língua inglesa. Cadernos de Pesquisa, São Paulo, n. 112, p. 33 - 60, mar. 2001.

MORAES, Roque. Análise de conteúdo. Revista Educação, Porto Alegre, v. 22, n. 37, p. 7-32, 1999.

MOSCOVICI, S. Representações Sociais: investigação em Psicologia Social. Petrópolis, RJ: Vozes, 2011.

MÜLLER, F. (2007). Entrevista com William Corsaro. Educação e Sociedade, v. 28, p. 271 - 278. http://www.fe.unb.br/linhas-criticas/quem-e-quem/docentes/f/fernandamuller/minhas\%20publicacoes/artigos/entrevista-com-william-corsaro.

OLIVEIRA, Zilma R. Educação Infantil: fundamentos e métodos. São Paulo: Cortez, 2010.

PAPALIA, Diane; OLDS, Sally. Desenvolvimento Humano. 7. ed. Porto Alegre: Artes Médicas, 2000.

POSTMAN, Neil. O desaparecimento da infância. Tradução de Suzana Menescal de Alencar Carvalho e José Laurenio de Melo. Rio de Janeiro: Graphia, 1999. 
PROUT, A. Reconsiderar a nova sociologia da infância. Braga: Universidade do Ninho; Instituto de Estudos da Criança, 2004.

QUINTEIRO, J. Sobre a emergência de uma sociologia da Infância: contribuições para o debate. Perspectiva. Florianópolis, v. 20, n. especial, p. 137-162, jul/dez, 2002.

QVORTRUP, Jens. Macro-Análise da Infância. In: CHRISTENSEN, Pia; ALLISON, James (Org.). Investigação com Crianças - Perspectivas e Práticas. Paula Frassinetti, 2005.

ROSSETI-FERREIRA. M. C. Uma perspectiva teórico-metodológica para análise do desenvolvimento humano e do processo de investigação. Psicologia: Reflexão e Crítica, v.13, n.2, 2000, p.281 - 293.

SARMENTO, M. J. e CERISARA, A. B. (orgs.). Crianças e Miúdos: Perspectivas sociopedagógicas da infância e educação. Porto: Asa, 2004.

M. J. e PINTO, M. As crianças, contextos e identidades. Braga, Portugal. Universidade do Ninho. Centro de Estudos da Criança. Ed. Bezerra, 1997.

SÁ, C. P. Representações Sociais: o conceito e o estado atual da teoria. In: M. J. Spink (org.) O conheccimento cotidiano. São Paulo: Brasiliense. p. 19 - 45. 1993.

Rio de Janeiro: Ed. UERJ, 1998.

SIROTA, R. Emergência de uma sociologia da infância: evolução do objeto e do olhar. Cadernos de Pesquisa, São Paulo, n. 112, p. 7-31, mar. 2001.

SOBRINHO, M. D. Revista De Ciências Humanas E Artes, Campina Grande, v. 16, n. $1 / 2$, p. $31-48$, jan./dez. 2010.

TARDIF, Maurice. Saberes docentes e formação profissional. Rio de Janeiro: Vozes, 2012.

VÈRGES, P. Conjunto de programas que permitem a análise de evocações: EVOC: manual. Versão 5. Aix en Provence: [S. n.\} 2002.

VIANNA, C. P.; RIDENTI, S. G. U. Relações de gênero e escola: das diferenças ao preconceito. In: AQUINO, J. G. (org.) Diferenças e preconceitos na escola: alternativas teóricas e práticas. São Paulo: Summus, 1998. p. 93 - 106.

VIGOTSKI, L. S. A Formação Social da Mente. Martins Fontes, 2008.

WAGNER, W. Descrição, explicação e método na pesquisa das Representações Sociais. In: - GUARESCHI, P. e JOVCHELOVICTH, S. Textos em representações sociais. Petrópolis: Vozes, 2013. p. 119 - 150.

WERLE, Flávia O.C. Escola Normal Rural no Rio Grande do Sul: história institucional. Diálogo Educacional Curitiba, PUCPR, v.5, n.14, p. 35 - 50, jan./abr.2005. 
APÊNDICE A: TERMO DE CONSENTIMENTO LIVRE E ESCLARECIDO - 1

PARA COORDENAÇÃO REGIONAL DE ENSINO DO RECANTO DAS EMAS

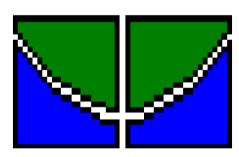

UNIVERSIDADE DE BRASÍLIA

FACULDADE DE EDUCAÇÃO

PROGRAMA DE PÓS-GRADUAÇÃO EM EDUCAÇÃO

\section{TERMO DE CONSENTIMENTO LIVRE E ESCLARECIDO}

Senhor Coordenador,

Sou Adail Silva Pereira dos Santos, professor da Secretaria de Estado de Educação do Distrito Federal, atualmente cursando Mestrado do Programa de PósGraduação em Educação - Faculdade de Educação - Universidade de Brasília e estou realizando uma pesquisa cujo tema "INFÂNCIA E CRIANÇA: UM ESTUDO EM REPRESENTAÇÕES SOCIAIS COM PROFESSORES DOS CENTROS DE EDUCAÇÃO DA PRIMEIRA INFÂNCIA - CEPI/DF” tem orientação da Profa. Dra. Teresa Cristina Siqueira Cerqueira.

Em razão disso, solicito a sua autorização para que os professores dos Centros de Educação da Primeira Infância da Secretaria de Estado de Educação do Distrito Federal, sob responsabilidade da Coordenação Regional de Ensino do Recanto das Emas, participem como sujeitos dessa pesquisa.

Esclarecemos que as informações colhidas serão utilizadas academicamente nesta pesquisa, ao mesmo tempo em que garantimos o anonimato dos sujeitos participantes.

Certos de podermos contar com sua colaboração, antecipadamente agradecemos e colocamo-nos à disposição para quaisquer esclarecimentos a respeito desse trabalho.

Atenciosamente,

Adail Silva Pereira dos Santos

(Mestrando)
Teresa Cristina S. Cerqueira

(Orientadora)

Contato: adaylsantos@ hotmail.com 


\section{Autorização:}

$\mathrm{Eu}$ autorizo os professores do Centro de Educação da Primeira Infância da Secretaria de Estado de Educação do Distrito Federal que estão sob a responsabilidade da Coordenação Regional de Ensino do Recanto das Emas a participarem da pesquisa de Mestrado em Educação, acima identificada, sob a coordenação do Prof. Adail Silva Pereira dos Santos.

Assinatura:

RG:

Obs: Este modelo será aplicado também para a Coordenação Regional de Santa Maria, com as devidas adaptações. 


\section{APÊNDICE B: TERMO DE CONSENTIMENTO LIVRE E ESCLARECIDO - 2 PARA PARTICIPAÇÃO NA PESQUISA}

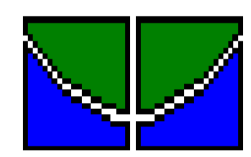

\section{UNIVERSIDADE DE BRASÍLIA}

FACULDADE DE EDUCAÇÃO

PROGRAMA DE PÓS-GRADUAÇÃO EM EDUCAÇÃO

TERMO DE CONSENTIMENTO LIVRE E ESCLARECIDO

$\mathrm{Eu}$

RG,

CPF: autorizo $\quad \mathrm{O}$

pesquisador Adail Silva Pereira dos Santos, mestrando do Programa de Pós-Graduação em Educação - Faculdade de Educação - Universidade de Brasília, cujo projeto de pesquisa é denominado "INFÂNCIA E CRIANÇA: UM ESTUDO EM REPRESENTAÇÕES SOCIAIS COM PROFESSORES DOS CENTROS DE EDUCAÇÃO DA PRIMEIRA INFÂNCIA - CEPI/DF”, sob orientação da Profa. Dra. Teresa Cristina Siqueira Cerqueira, a utilizar-se das informações obtidas na aplicação do questionário de evocação livre de palavras, da qual participo, obedecendo aos critérios da ética de pesquisa, onde está assegurado o total anonimato.

Declaro-me ciente e concordo com o acima exposto. 
APÊNDICE C: INSTRUMENTO PARA ELUCIDAR O PERFIL DOS PROFESSORES DOS CENTROS DE EDUCAÇÃO DA PRIMEIRA INFÂNCIA DA SECRETARIA DE ESTADO DE EDUCAÇÃO DO DISTRITO FEDERAL SOB A RESPONSABILIDADE DA COORDENAÇÃO REGIONAL DE ENSINO DO RECANTO DAS EMAS

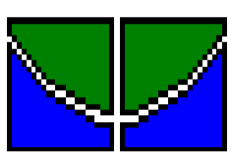

\section{UNIVERSIDADE DE BRASÍLIA}

FACULDADE DE EDUCAÇÃO

PROGRAMA DE PÓS-GRADUAÇÃO EM EDUCAÇÃO

CARACTERIZAÇÃO DOS PARTICIPANTES DA PESQUISA

a) Qual a sua idade?

b) Sexo: ( ) $\mathrm{M}($ ) $\mathrm{F}$

c) Tem filhos? ( ) sim ( ) não. Quantos?

d) O que você nos diz sobre sua vida profissional?

e) Qual a sua formação:

( ) Ensino Médio:

( ) Curso Superior:

( ) Especialização:

( ) Mestrado:

( ) Doutorado:

( ) Outros:

f) Atuação na Educação Infantil (anos):

g) Séries/ano que você já atuou como professor (a):

h) Você participa de algum grupo acadêmico, cultural, religioso, artístico ou desportivo? 
( ) $\operatorname{sim}$ ( ) não Qual (is)?

( ) dança ( ) teatro ( ) coral ( ) capoeira ( ) grupo de estudo/pesquisa

( ) natação/futebol/etc ( ) igreja ( ) partido político

( ) outros

i) Pratica alguma religião? ( ) sim ( ) não Qual?

j) O que você mais gosta de fazer quando não está trabalhando?

k) O que você mais gosta de fazer na sua sala de aula?

1) E o que você não gosta de fazer na sua sala de aula?

m)O que mais lhe agrada na profissão de professor (a) da Educação Infantil?

Obs: Este mesmo modelo será aplicado para os professores da Coordenação Regional de Ensino de Santa Maria, com as devidas adaptações. 
APÊNDICE D: INSTRUMENTO DE EVOCAÇÃO LIVRE DE PALAVRAS PARA OS PROFESSORES DOS CENTROS DE EDUCAÇÃO DA PRIMEIRA INFÂNCIA DA SECRETARIA DE ESTADO DE EDUCAÇÃO DO DISTRITO FEDERAL SOB A RESPONSABILIDADE DA COORDENAÇÃO REGIONAL DE ENSINO DO RECANTO DAS EMAS

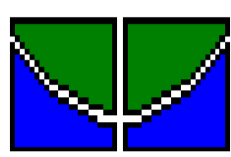

\section{UNIVERSIDADE DE BRASÍLIA}

FACULDADE DE EDUCAÇÃO

PROGRAMA DE PÓS-GRADUAÇÃO EM EDUCAÇÃO

Profa. Responsável: Dra. Teresa Cristina Siqueira Cerqueira - UnB

Mestrando: Adail Silva Pereira dos Santos - (mestrando do Programa de PósGraduação em Educação - Faculdade de Educação - Universidade de Brasília, cujo projeto de pesquisa é denominado "INFÂNCIA E CRIANÇA: UM ESTUDO EM REPRESENTAÇÕES SOCIAIS COM PROFESSORES DOS CENTROS DE EDUCAÇÃO DA PRIMEIRA INFÂNCIA - CEPI/DF").

Estamos realizando uma pesquisa para a qual necessitamos da sua colaboração. Por não se tratar de uma pesquisa de avaliação, não há respostas certas ou erradas, apenas queremos conhecer a sua compreensão. Esteja certo de que será garantido o anonimato e que os dados coletados serão utilizados academicamente nesta pesquisa. Desde já, agradecemos a sua participação.

1- O senhor (a) poderia dizer as seis palavras, ou expressões, que lhe vêm logo à cabeça quando se fala em Criança.

\begin{tabular}{|l|}
\hline $1-$ \\
\hline $2-$ \\
\hline $3-$ \\
\hline $4-$ \\
\hline $5-$ \\
\hline $6-$ \\
\hline
\end{tabular}


2- Agora, separe por ordem de importância três palavras que você usou no quadro acima e que, na sua opinião, são as mais importantes:

\begin{tabular}{|l|}
\hline $1-$ \\
\hline $2-$ \\
\hline $3-$
\end{tabular}

3- Dê o significado da palavra que você considerou como sendo a mais importante, ou seja, aquela que está em $1^{\circ}$ lugar:

Obs.: Esta é a primeira etapa da pesquisa. Caso tenha interesse em fazer parte da segunda etapa para formarmos um grupo focal onde daremos continuidade ao tema por meio de discussões e trocas de idéias, favor preencher as informações a seguir (para maiores esclarecimentos, entre em contato com Adail pelo email adaylsantos@hotmail.com):

$\square$ Sim, tenho interesse em continuar participando da pesquisa

$\square$ Não tenho interesse em continuar participando da pesquisa

Nome

email:

telefone:

Obs: Este mesmo modelo será aplicado para os professores da Coordenação Regional de Ensino de Santa Maria, com as devidas adaptações. 
APÊNDICE E: INSTRUMENTO DE EVOCAÇÃO LIVRE DE PALAVRAS PARA OS PROFESSORES DOS CENTROS DE EDUCAÇÃO DA PRIMEIRA INFÂNCIA DA SECRETARIA DE ESTADO DE EDUCAÇÃO DO DISTRITO FEDERAL SOB A RESPONSABILIDADE DA COORDENAÇÃO REGIONAL DE ENSINO DO RECANTO DAS EMAS

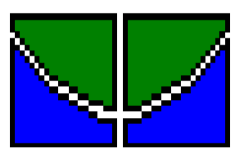

UNIVERSIDADE DE BRASÍLIA

FACULDADE DE EDUCAÇÃO

PROGRAMA DE PÓS-GRADUAÇÃO EM EDUCAÇÃo

Profa. Responsável: Dra. Teresa Cristina Siqueira Cerqueira - UnB

Mestrando: Adail Silva Pereira dos Santos - (mestrando do Programa de PósGraduação em Educação - Faculdade de Educação - Universidade de Brasília, cujo projeto de pesquisa é denominado "INFÂNCIA E CRIANÇA: UM ESTUDO EM REPRESENTAÇÕES SOCIAIS COM PROFESSORES DOS CENTROS DE EDUCAÇÃO DA PRIMEIRA INFÂNCIA - CEPI/DF”).

Estamos realizando uma pesquisa para a qual necessitamos da sua colaboração. Por não se tratar de uma pesquisa de avaliação, não há respostas certas ou erradas, apenas queremos conhecer a sua compreensão. Esteja certo de que será garantido o anonimato e que os dados coletados serão utilizados academicamente nesta pesquisa. Desde já, agradecemos a sua participação.

1- O senhor (a) poderia dizer as seis palavras, ou expressões, que lhe vêm logo à cabeça quando se fala em Infância.

\begin{tabular}{|l|}
\hline $1-$ \\
\hline $2-$ \\
\hline $3-$ \\
\hline $4-$ \\
\hline $5-$ \\
\hline $6-$ \\
\hline
\end{tabular}


2- Agora, separe por ordem de importância três palavras que você usou no quadro acima e que, na sua opinião, são as mais importantes:

\begin{tabular}{|l|}
\hline $1-$ \\
\hline $2-$ \\
\hline $3-$ \\
\hline
\end{tabular}

3- Dê o significado da palavra que você considerou como sendo a mais importante, ou seja, aquela que está em $1^{\circ}$ lugar:

Obs.: Esta é a primeira etapa da pesquisa. Caso tenha interesse em fazer parte da segunda etapa para formarmos um grupo focal onde daremos continuidade ao tema por meio de discussões e trocas de idéias, favor preencher as informações a seguir (para maiores esclarecimentos, entre em contato com Adail pelo email adaylsantos@hotmail.com):

$\square$ Sim, tenho interesse em continuar participando da pesquisa

$\square$ Não tenho interesse em continuar participando da pesquisa

Nome

email:

telefone:

Obs: Este mesmo modelo será aplicado para os professores da Coordenação Regional de Ensino de Santa Maria, com as devidas adaptações. 
ANEXO A

IMAGENS PROJETADAS PARA O GRUPO FOCAL
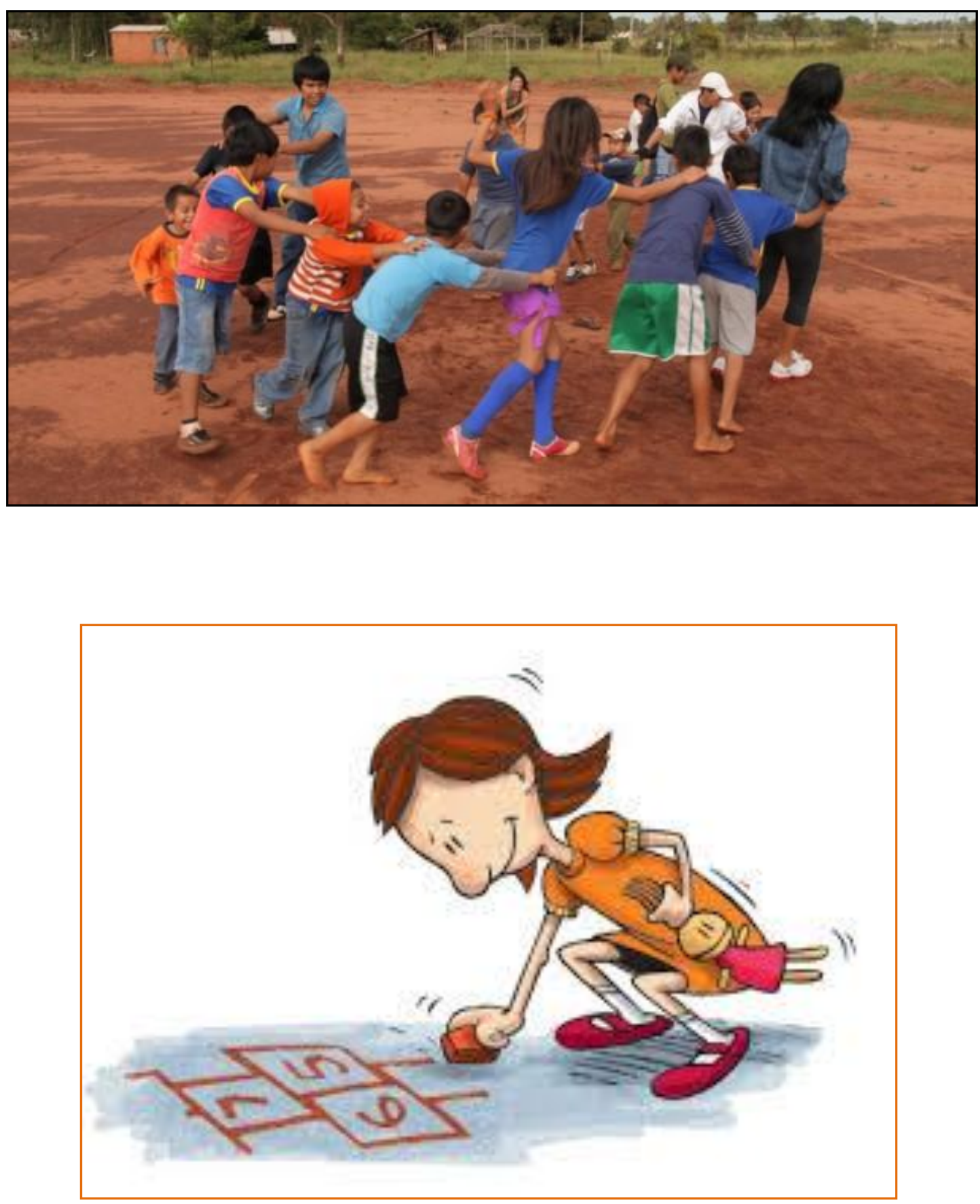

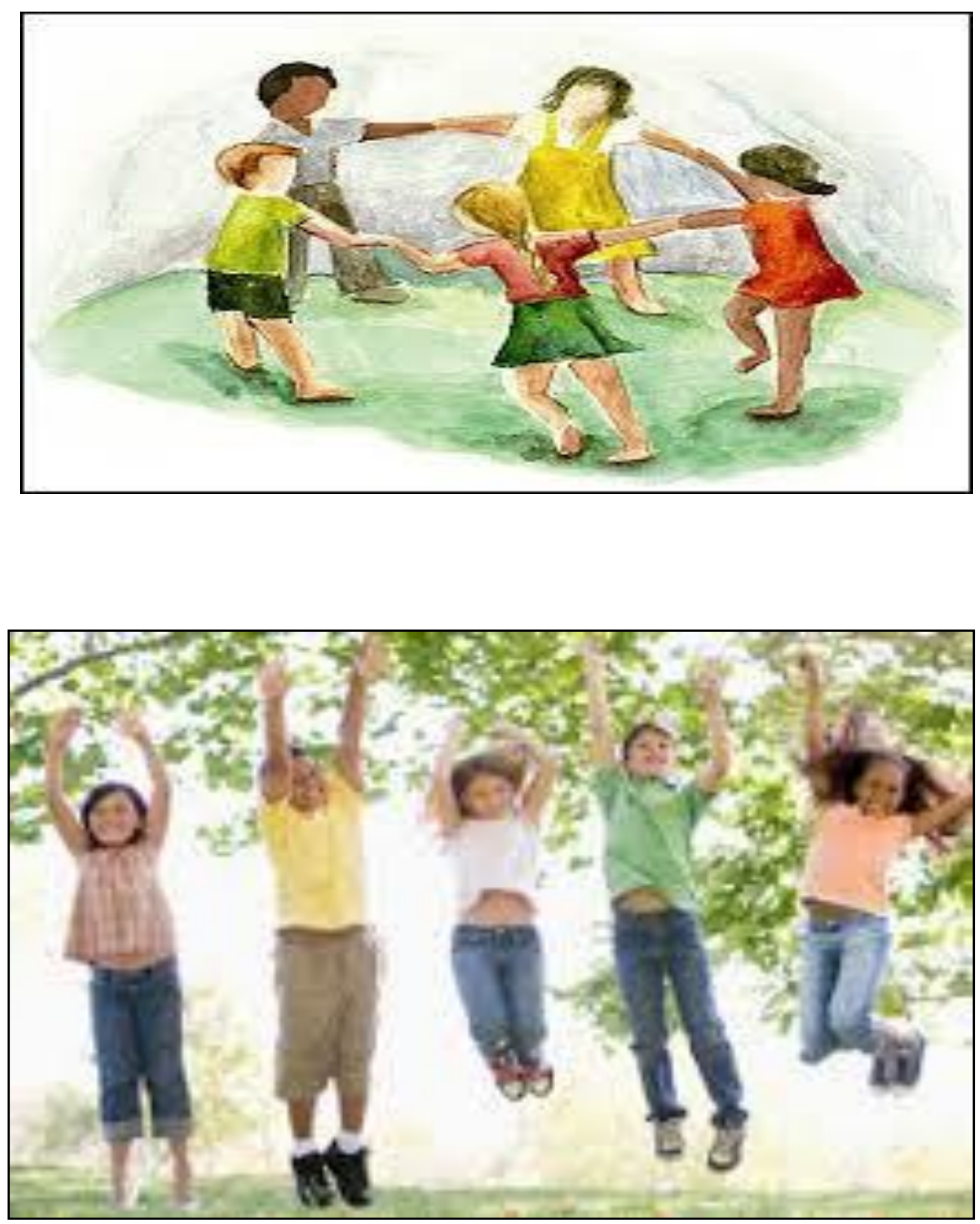

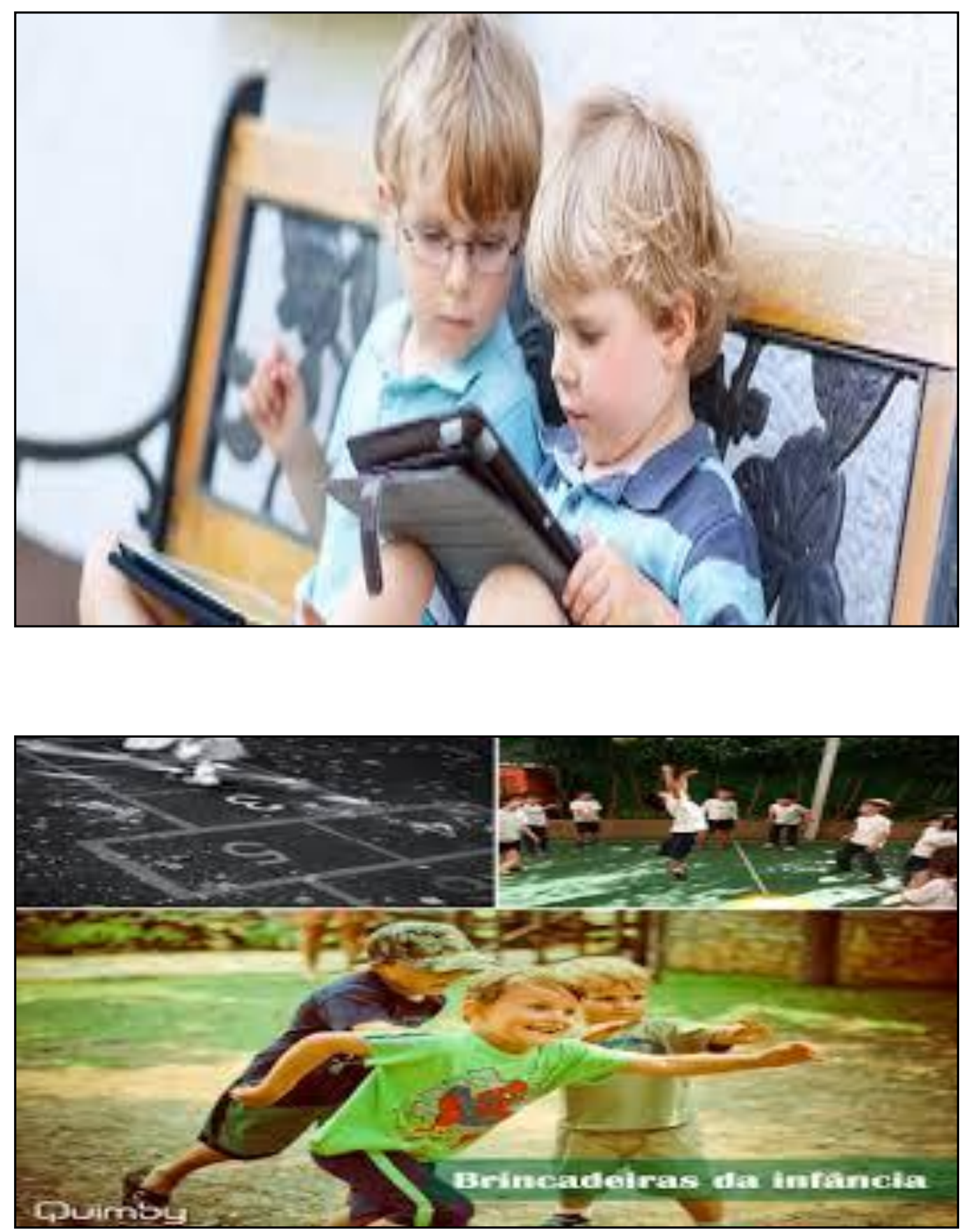

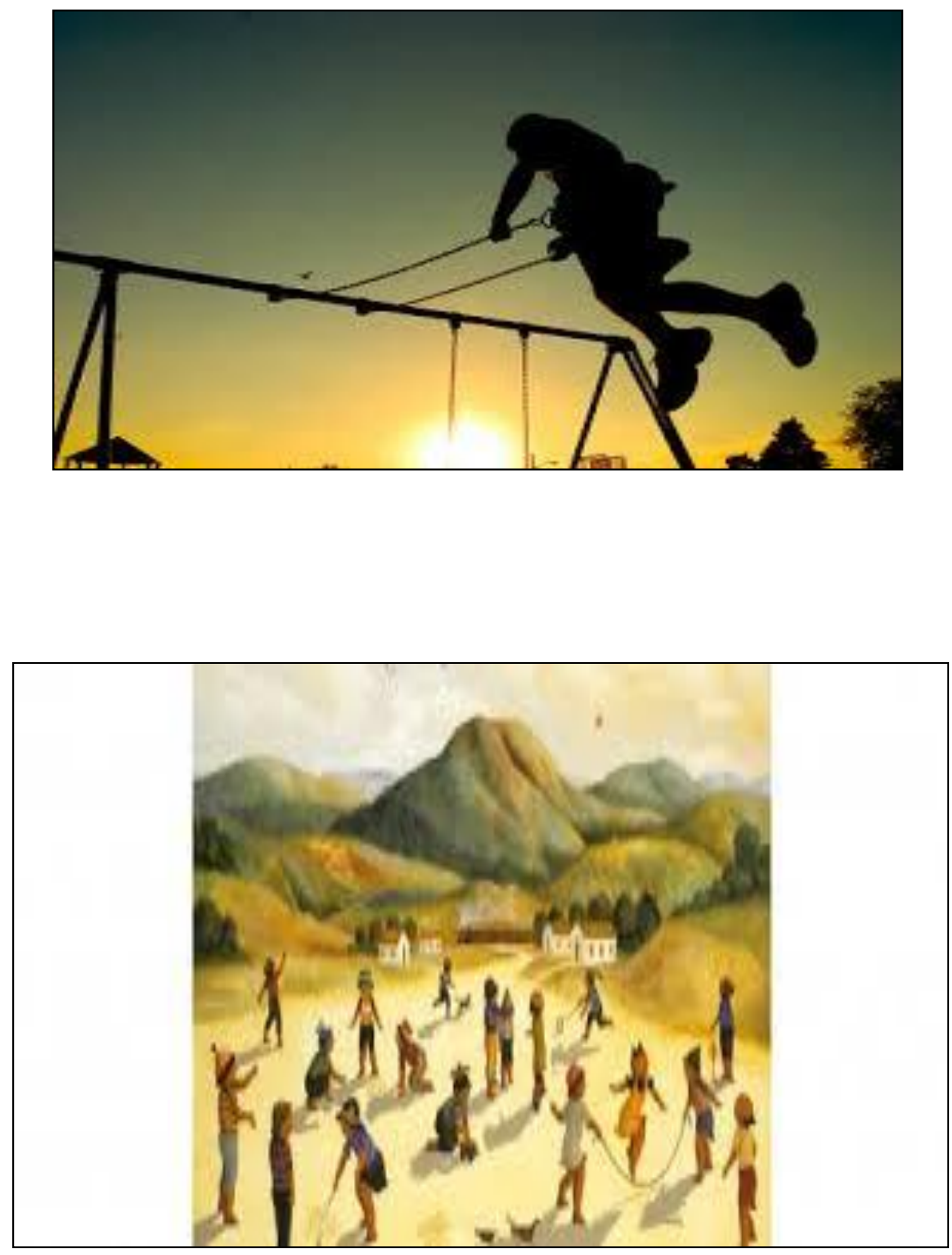